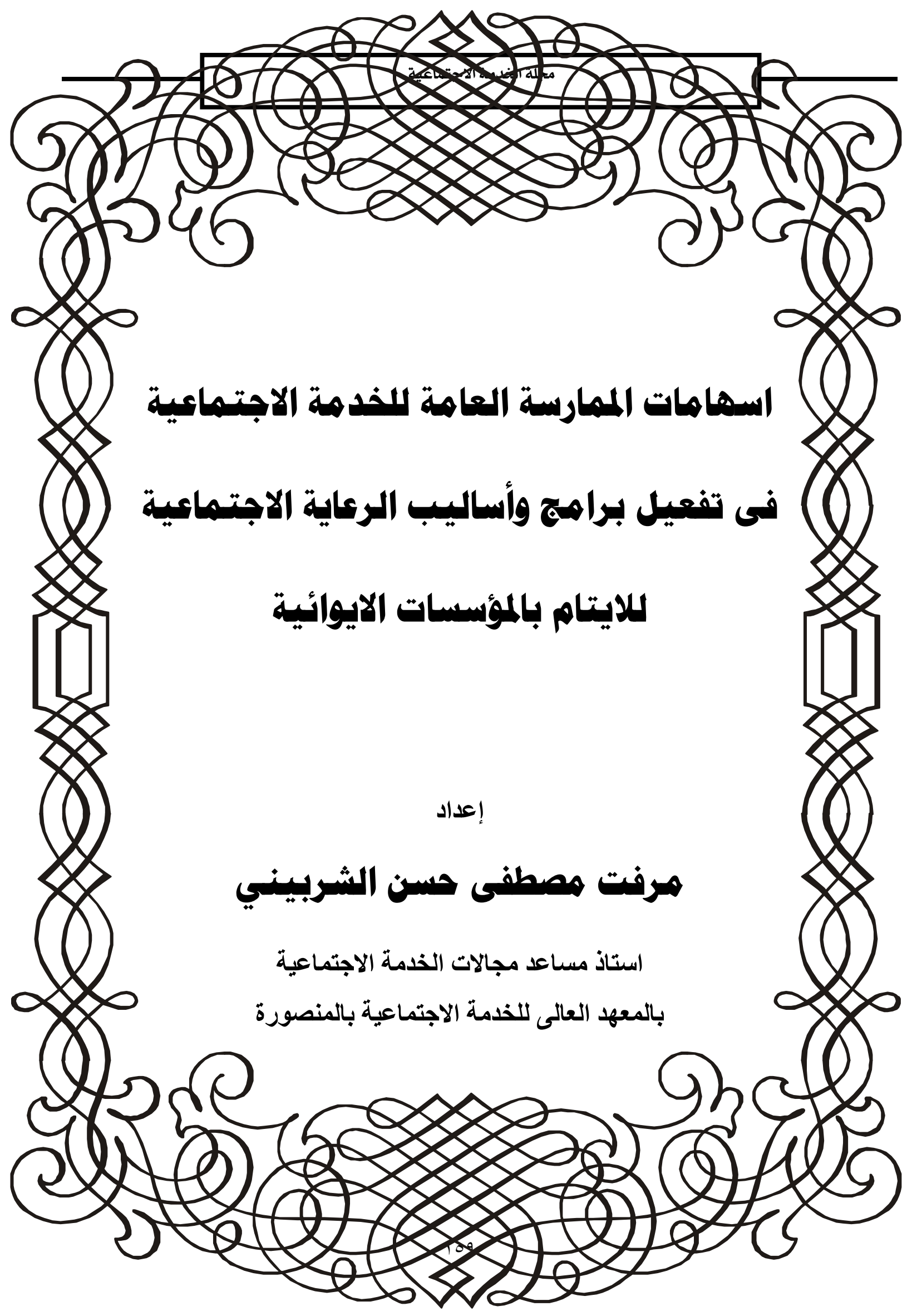




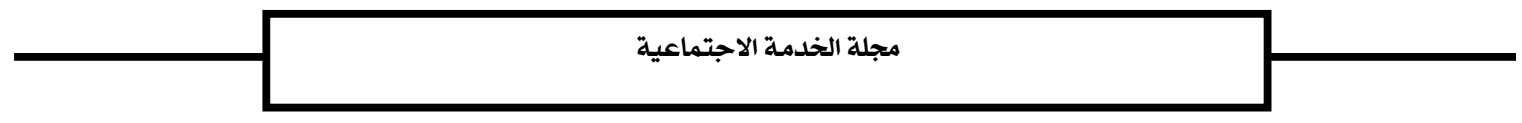




\section{أولا : مشكلة الدراسة :}

يعد الأطفال فى أي بجتمع هم أساس استمراره ونموه المطرد وهم الطاقة البشرية المنتظرة

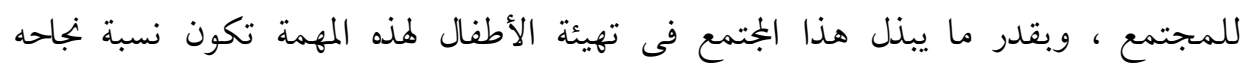
واستفادته من هذه القوي البشرية الواعدة ، فالعناية بها ضرورة شرعية ، واجتماعية ،

و اقتصادية (1)

ولقد نالت رعاية الطفولة قدراً كبيراً من الاهتمام نظراً لتزايد اعداد هذه الفئة فى العالم بشكل واضح حيث تجاوزت مليار نسمة على المستوي العلمي (r) . بينما على المستوي القومي

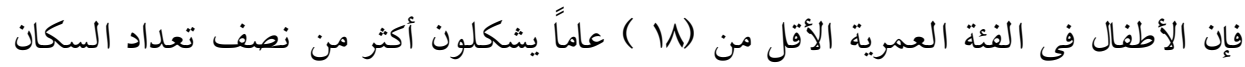

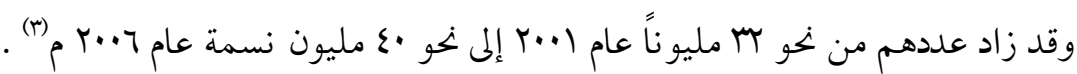

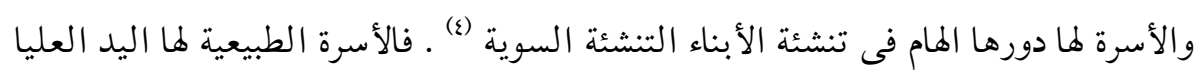
فى التنشئة الاجتماعية للابناء واكسابهم الشخصية المتزنة الواقعية المتكيفة صحياً ونفسياً (ه) . وعلى الرغم من الاتفاق على الأثر الواضح لدور الأسرة فى حياة الطفل إلا أن العديد من

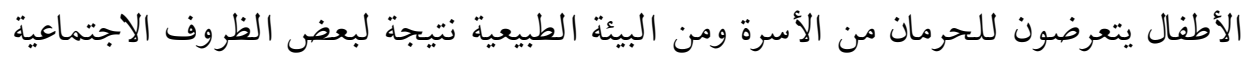

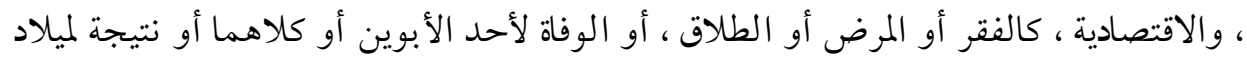
غير شرعي (7) ـ وينتج عن ذلك تعرض هؤلاء الأطفال لمشكلات عديدة منها عدم الاحساس بالأمن والطمأنينة ، سلبية العلاقات الاجتماعية ، والنقص فى العلاقات العاطفية ، وكذلك

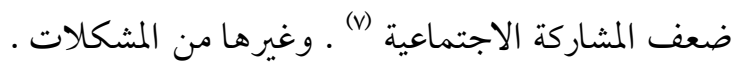

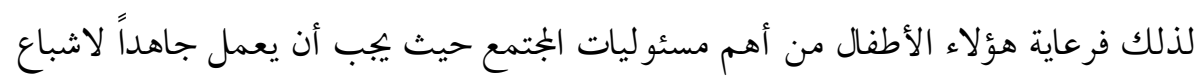
احتياجاتهم ليس فقط بل مواجهة وحل مشكلاتهم • ونتيجة للزيادة المستمرة والمضطردة لفئة الخرومين من الرعاية الأسرية الطبيعية فالدول تبذل كافة الجهود من خلال الأجهزة والمنظمات والوزارات المختلفة لتوفير وإنشاء مؤسسات لإيواء ورعاية هؤلاء الأطفال ـ حيث أن المؤسسات الايوائية يمكن اعتبارها الحل البديل لتوفير أوجه الرعاية التى تكفل لهؤلاء الأطفال الخرومين من الرعاية الأسرية الحياة الكريمة (') . ولذلك قد ارتفع علد المؤسسات الايوائية النى ترعي الأيتام وأخذت فى الانتشار بصورة

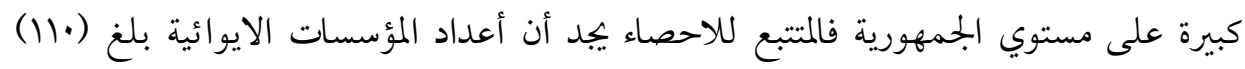




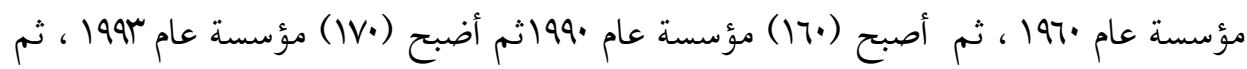

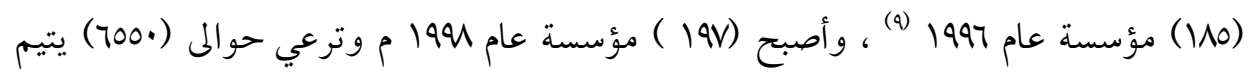

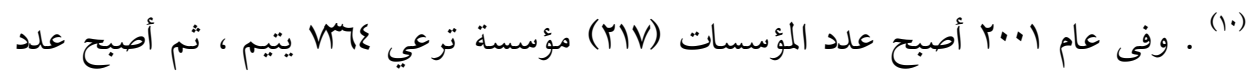

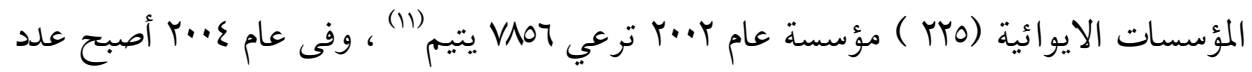

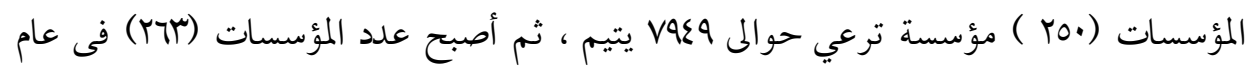

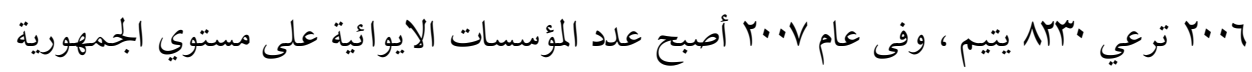

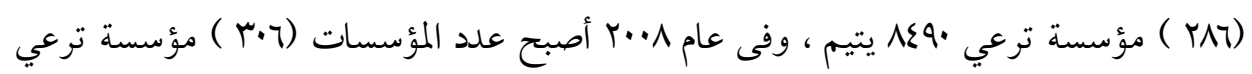
- (r) 1 (1)

والمؤسسات الايوائية هي كل دار لايواء الأطفال المعرضين للانحراف بسبب اليتم أو التفكك أو تصدع الأسرة وفقا لما يسفر عنه البحث الاجتماعي ومن أغراضها توفير أوجه

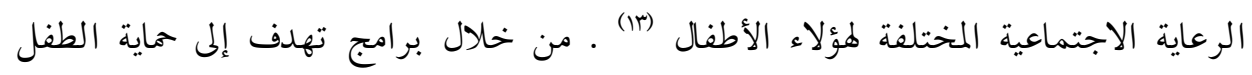

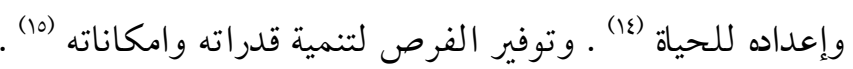

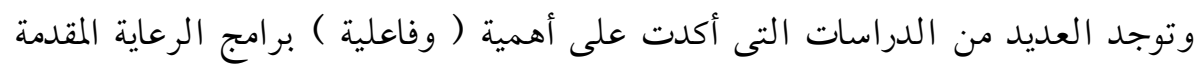
للأطفال فى المؤسسات الايوائية ومنها :

ا-دراسة كليمر برنجل prngle M.K. 19 م م (1) : وقد أكدت على أن الرعاية

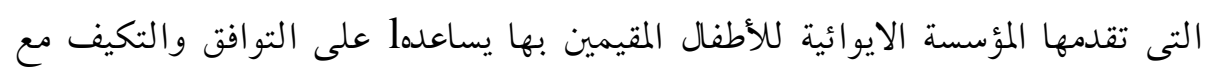
أنفسهم ومع الجتمع الذى يعيشون به كذلك يخفف من بعض الآثار التى قد تكون سلبية نتيجة ايداعهم فى المؤسسة . ץ-دراسة جمال شفيق أحمد 1917 م (V): توصزg هذه الدراسة إلى أن ارتفاع مستوي الرعاية المقدمة للأطفال المودعين فى المؤسسات الايوائية ينمي العديد من السمات الشخصية المميزة لديهم .

ب-دراسة فاطمة حنفى محمود 1819 م (1)): أكدت الدراسة على أن أساليب وبرامج الرعاية المقدمة للأطفال فى المؤسسات الايوائية يجسن من قدرات التفكير الابتكاري لدي هؤلاء الأطفال . 
ع-دراسة بالميرس كيرستين 1991 م (19) : أكدت نتائج الدراسة على أنه كلما ارتفعت

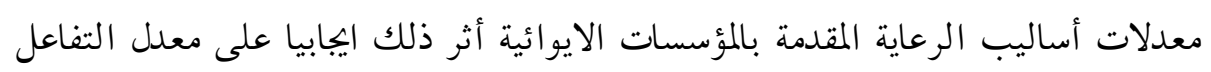

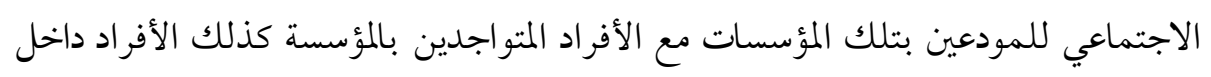

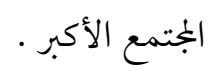

ه-دراسة هناء أبو شهبه 1999 م (.) : : أثبتت أن أساليب الرعاية المقدمة للأطفال فى بعض المؤسسات الايوائية يزيد قدراتهم على التوافق كذلك يزيد من قدرتهم على

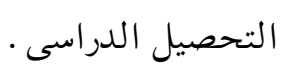

צ-دراسة مها صلاح الدين محمد حسن سو199 (r) : وقد أكدت على أن برامج الرعاية المقدمة للأطفال بالمؤسسات الايوائية لها أهميتها فى علاج المشكلات الاجتماعية وازالة

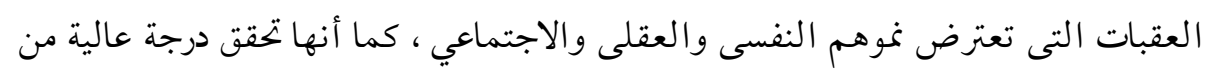

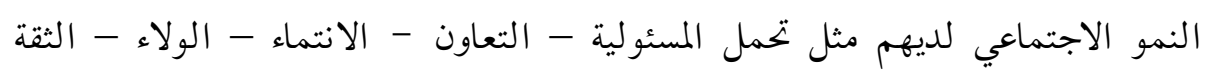
بالنفس... إلخ . V-دراسة لوفرزيمر 199\&Laufer Zmra م (rr): توصلت هذه الدراسة إلى أن أنشطة وبرامج الرعاية التى تقدمها المؤسسة الايوائية للأطفال المودعين بها تزيد من احساس هؤلاء الأطفال بذاتهم كما أنها تساهم فى تقوية الهوية الشخصية المستقلة لهؤلاء الأطفال .

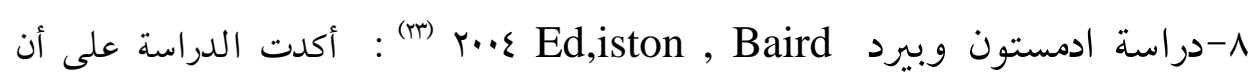
مستوي الرعاية المقدمة من المؤسسة يؤثر على مستوي توافق الأيتام العام والشخصى والاجتماعي فكلما ارتفع مستوي الرعاية ارتفع مستوي التوافق لديهم . ه-دراسة بريستى 2008 Presciutti (צ') : اكدت الدراسة أن برامج الرعاية المقدمة بالمؤسسات الايوائية خاصة البرامج التعليمية يسهم فى خلق فرص للدخل للمودعين بتلك

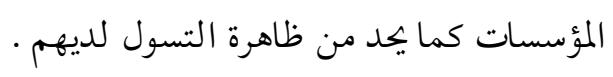
ولأن الخدمة الاجتماعية تعتبر من المهن الأساسية التى تعمل فى بجال رعاية الطفولة

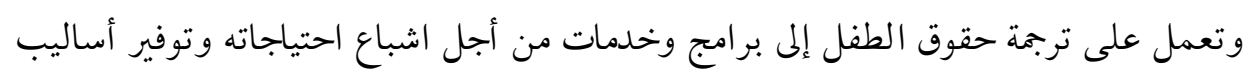

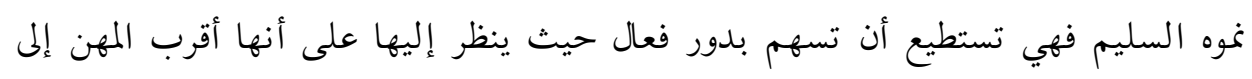


الانسان فهي تتعامل مع قدراته الذاتية عمع التركيز لى احتياجاته ومشكلاته (ro) ـ. لذلك نجد

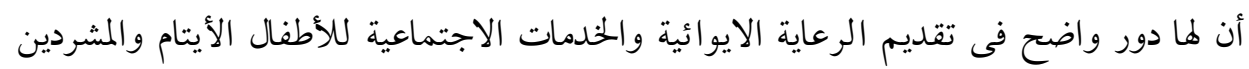
والمنبوذين المودعين بالمؤسسات الايوائية ولقد أثبتت فاعليتها ويؤكد ذلك دراسات منها : 1- دراسة انهام إبراهيم عبد العزيز •199 (ri) : توصلت هذه الدراسة إلى أن استخدام نموذج حل المشكلة فى طريقة خدمة الفرد يؤدي إلى زيادة التوافت النفسى والاجتماعي للأطفال الخرومين من الرعاية الوالدية . r- دراسة يوسف لطفى 199V م (YV): أكدت هذه الدراسة فاعلية التدخل المهني لطريقة خدمة الفرد فى تعديل مفهوم الذات لدي المودعين بالمؤسسات الايوائية وبالتالى يؤدي ذلك إلى تحقيق درجة عالية من التفاعل الاجتماعي والعلاقات الاجتماعية الايجابية . r- دراسة إبراهيم محمد إبراهيم 1999 م (N) : أكدت الدراسة على أن وضع نموذج للممارسة العلاجية للخدمة الاجتماعية داخل المؤسسات الايوائية يمكن من خلاله علاج مشكلتي الخوف والانطواء ويدعم تقدير الذات لدي الأطفال المودعين بتلك المؤسسة .

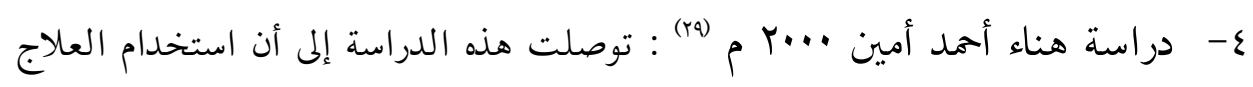
المتركز حول العميل فى خدمة الفرد له فاعلية فى تعديل مفهوم الذات لدى الأطفال

$$
\text { المودعين فى المؤسسات الايوائية . }
$$

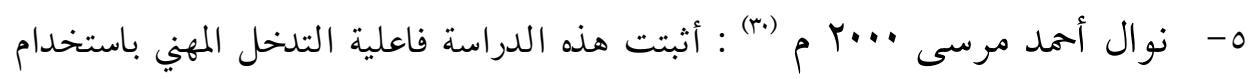
نووذج التركيز على المهام فى خدمة الفرد فى التخفيف من حدة مشكلات اضطراب

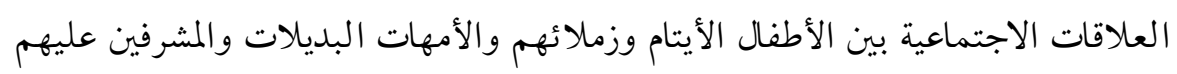

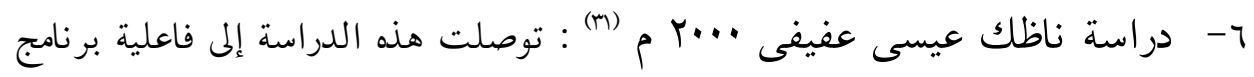
للعمل مع جماعات الأطفال بالمؤسسات الايوائية فى تعديل السلوك اللاتوافقى لهؤلاء الأطفال مثل ( التمرد ، العدوان ، الانسحاب ) ). 


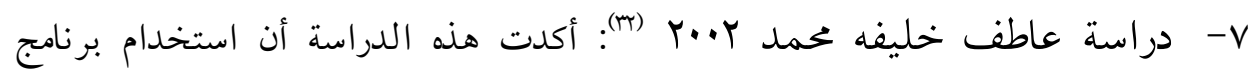
للتدخل المهني للخدمة الاجتماعية يؤدي إلى التخفيف من حدة المشكلات النفسية والاجتماعية للأطفال بالمؤسسات الايو ائية ومنها السلوك العدواني والانطواء (ع)ب.

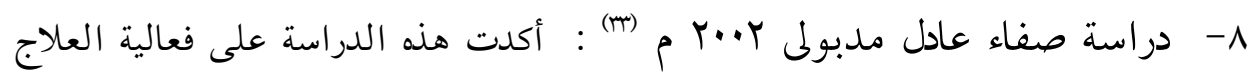
الواقعي فى تنمية المسئولية الاجتماعية لدي الأيتام بالمؤسسات الايوائية.

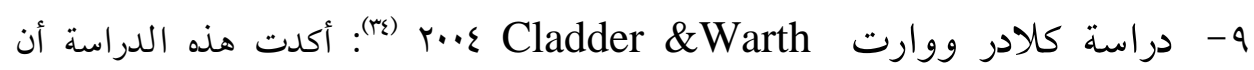
استخدام برنامج علاجي للسلوك المعرفى على المودعين بالمؤسسات الايوائية يزيد من رغبة هؤلاء الأطفال فى التخلص من مشاعر التمرد والعدوانية ، وخلق رغبة قوية لديهم

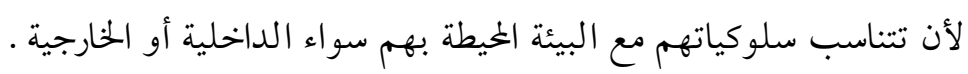

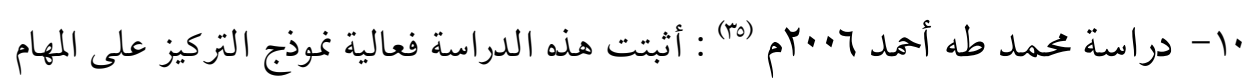
فى خدمة الفرد فى تحسين الأداء الاجتماعي للأطفال الأيتام بالمؤسسات الايوائية وذلك

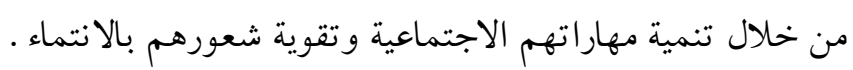
|l- دراسة عبير نيازي وحيد r|•r (1) : توصلت هذه الدراسة إلى أن استخدام برنامج للتدخل المهني من منظور الممارسة العامة فى الخدمة الاجتماعية يقى الأطفال المودعين

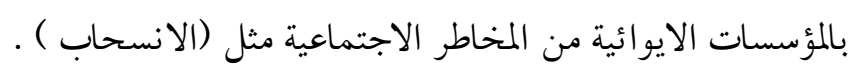
rا- دراسة عزه محمد الطنبولى ع|+r (v) : اثبتت هذه الدراسة أن التدخل المهني من منظور الممارسة العامة فى الخدمة الاجتماعية يقى الأيتام المودعين بالمؤسسات الايوائية من

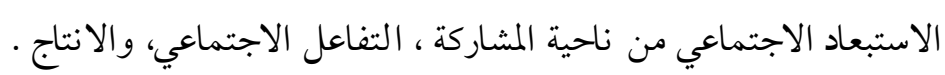
وعلى الرغم من كل ما توصلت إليه الدراسات السابقة نجد أن الأينام فى المؤسسات الايوائية

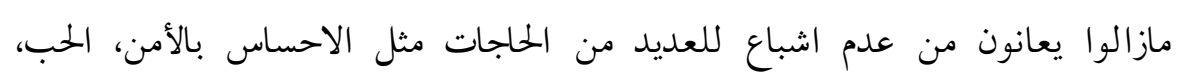

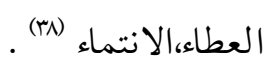

كما يعانون من العديد من المشكلات السلوكية كالسرقة والكذب والثأخر الدراسى (هa)،

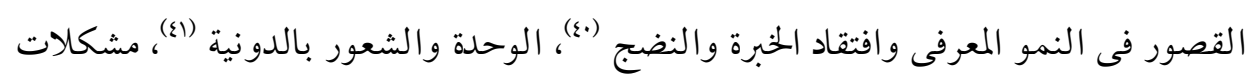


نفسية كالقلق والاكتئاب (ع) ، الخوف والانطواء وعدم تقدير الذات(r) ، عدم قدرتهم على تكون علاقات اجتماعية حميمية (๕).

وقد أرجعت العديد من الدراسات أن سبب ذلك يرجع إلى القصور فى برامج وأساليب

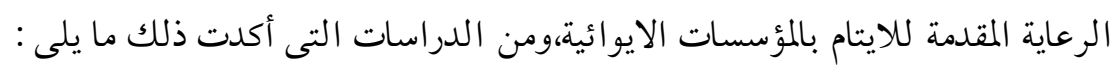
1- دراسة مني عطية خزام •199 (8)): أكدت هذه الدراسة إلى عدم فعالية الخدمات الاجتماعية المقدمة للايتام بالصورة المفترضة كذلك وجود العديد من المشكلات التى تواجه الأيتام فى الخصول على هذه الخدمات . ץ- دراسة هناء أحمد أمين محمد 1990 م (ح): أكدت هذه الدراسة على وجود العديد من المشكلات السلوكية للأطفال المقيمين بالمؤسسات الايوائية وقد أرجعت ذلك إلى وجود

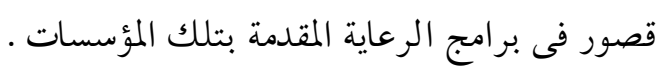

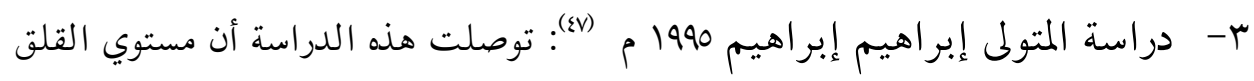
لدي الأطفال المودعين بالمؤسسات الايوائية مرتفع وقد ارجعت ذلك إلى أن هناك قصور فى برامج الرعاية المقدمة للأطفال بالمؤسسات الايوائيه. ع- دراسة كوهين १99V Cohen(ع) : أكدت الدراسة انخفاض مستوي الرعاية الاجتاعية المقدم للمودين بالمؤسسات الايوائية مما ينتج عنه العديد من المشكلات منها الانفصال عن البيئة الذى بدوره يؤدي إلى ضعف قدرة الأيتام على الارتباط بالآخرين وتكوين الإنين علاقات ايجابية . ه- دراسة بنامين وأخرين Bynmen And Olthers عدم الاهتمام بالمستوي التعليمي للأيتام داخل المؤسسات الايوائية مما يؤكد الخفاض مستوي اساليب وبرامج الرعاية التعليمية .

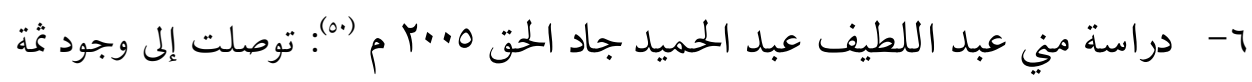
علاقة بين قصور برامج الرعاية الاجتماعية المقدمة لأبناء المؤسسات الايوائية والاضطر ابات السيكوسوماتية والانحرافات السلوكية لدي أبناء تلك المؤسسات . 


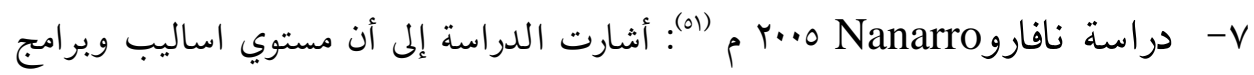
الرعاية التعليمية كذلك التدريب على مهارات التكنولوجيا الحديثة منخفض بالمؤسسات الايوائية مما يؤدي بالمودعين إلى استبعادهم عن سوق العمل ويالتالى استمرار حالتهم المادية المتدنية.

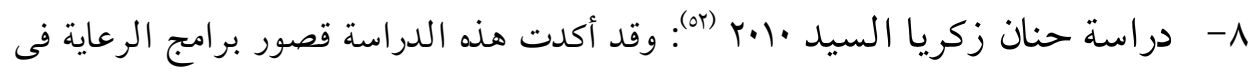
تحقيق أهدافها وأن هذه البرامج غير مشبعة وغير كافية لاحتياجات المودعات بالمؤسسة الايوائية .

\section{ومن بجمل ما سبق عرضه يتضح الآتي :}

1-أهمية برامج وأساليب الرعاية الاجتماعية المقدمة للأيتام بالمؤسسات الايوائية ( كليمر برنجل - جمال شفيق - فاطمة حنفى - هناء أبو شهبه - لوفر زيمرا - ادمستون وبيرد -

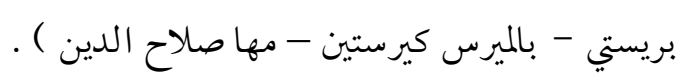

ب- أن الممارسة المهنية للخدمة الاجتماعية بصفة عامة لما دورها الايجابى فى تحقيق أهداف هذه بئه

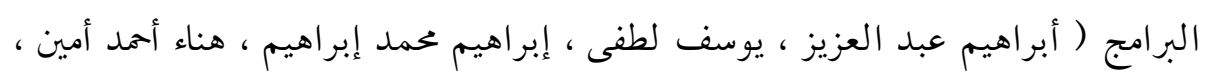

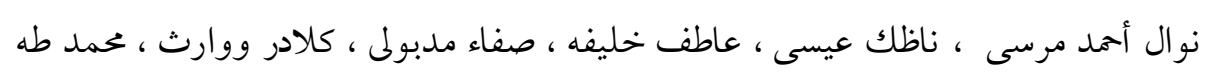

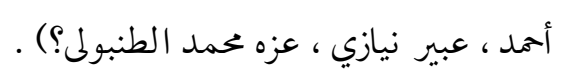

ب-مازالت توجد حاجات لم تشبع ، ومشكلات لم تواجه لدي الأيتام بالمؤسسات الايوائية

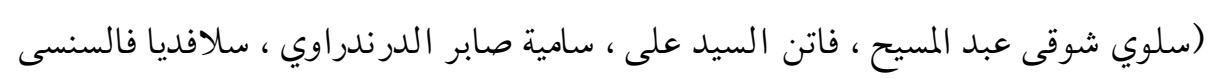

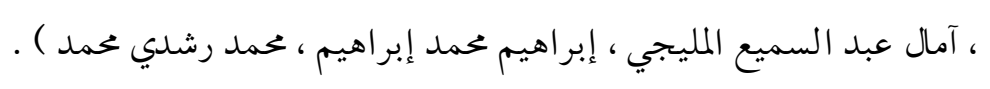

ع-أكدت الدراسات على وجود قصور فى برامج وأساليب الرعاية الاجتماعية المقدمة للأيتام

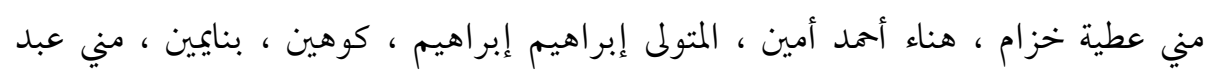

$$
\text { اللطيف ، نافارو ، حنان زكريا ). }
$$

ه-وقد ترآي للباحثة أنه يمكن أن تسهم الممارسة العامة للخدمة الاجتماعية فى تفعيل برامج

$$
\text { وأساليب الرعاية الاجتماعية للايتام بالمؤسسات الايوائية. }
$$

بذلك يمكن تحديد مشكلة الدراسة الحالية فيما يلى : 
اسهامات الممارسة العامة للخدمة الاجتماعية فى تفعيل برامج وأساليب الرعاية الاجتماعية

$$
\begin{aligned}
& \text { للأيتام بالمؤسسات الايوائية . } \\
& \text { ثانياً : أهمية الدراسة : }
\end{aligned}
$$

1- أن هذه الدراسة تهتم بتفعيل برامج وأساليب الرعاية الاجتماعية المقدمة للأيتام بالمؤسسات الايوائية لكي تزيد من قدرتها على اشباع احتياجات وحل مشكلات الأينام. r- أن هذه الدراسة تزيد من وعي الجتمع بأهمية المؤسسات الايوائية ودورها فى الاهتمام بالأطفال وخاصة المعرضين للخطر مما قد يزيد من مشاركة الجُتمع فى دعم تلك بكية المؤسسات . المست. r- التزايد المستمر فى أعداد الأطفال التى تعاني الحرمان من الرعاية الأسرية وتم ايداعهم فى المؤسسات الايوائية مما يستلزم التدخل المهني للخدمة الاجتماعية مع هذه الفئة .

\section{ثالثا : أهداف الدراسة :}

تسعي الدراسة الحالية لتحقيق الأهداف التالية :

ا- تحديد واقع استخدام الأخصائى الاجتماعي للممارسة العامة للخدمة الاجتماعية فى الحئي

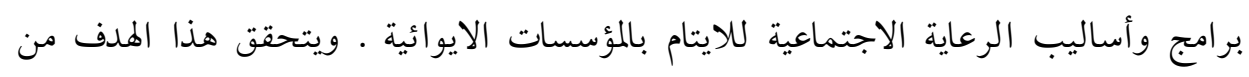
خلال الأهداف الفرعية التالية : برابل

أ- تحديد أدوات الممارسة العامة التى يستخدمها الأخصائى الاجتماعي فى برامج اليه

$$
\text { وأساليب الرعاية الاجتماعية للايتام بالمؤسسات الايوائية . }
$$

ب- تحديد أنشطة الممارسة العامة التى يستخدمها الاخصائى الاجتماعي فى برامج

$$
\text { وأساليب الرعاية الاجتماعية للأيتام بالمؤسسات الايوائية . }
$$

ج- تحديد مهارات الممارسة العامة النى يستخدمها الاخصائى الاجتماعي فى برامج لرابه

$$
\text { وأساليب الرعاية الاجتماعية للايتام بالمؤسسات الايوائية . }
$$

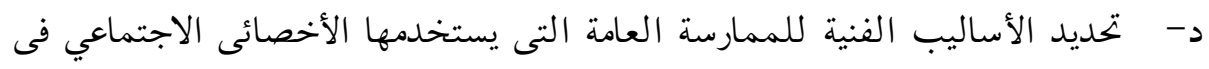
برامج وأساليب الرعاية الاجتماعية للايتام بالمؤسسات الايوائية . 
r- وضع رؤية مستتبلية لاسهامات الممارسة العامة للخدمة الاجتماعية فى تفعيل برامج وأساليب الرعاية الاجتماعية للايتام بالمؤسسات الايوائية . رابعاً: : تساؤلات الدراسة : برائ الحاية تسعي الدراسة الحالية للاجابة على التساؤلات الآتية :

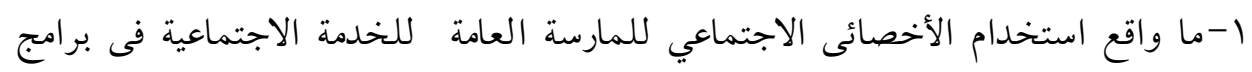
واساليب الرعاية الاجتماعية للايتام بالمؤسسات الايوائية ؟ ويتحقق هذا التساؤل بالاجابة عن التساؤلات الفرعية التالية :

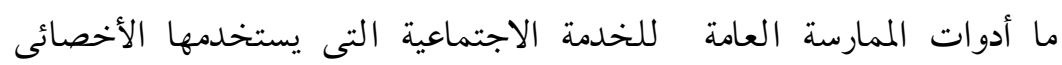
الاجتماعي فى برامج وأساليب الرعاية الاجتماعية للايتام بالمؤسسات الايوائية

(ب) ما أنشطة الممارسة العامة للخدمة الاجتماعية التى يستخدمها الأخصائى الاجتماعي فى برامج وأساليب الرعاية الاجتماعية للايتام بالمؤسسات الايوائية؟.

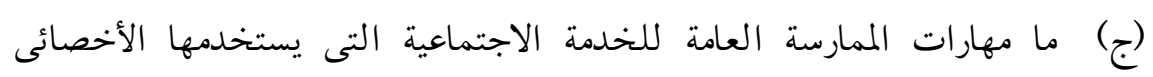

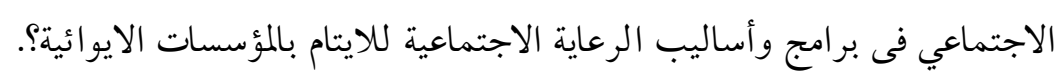

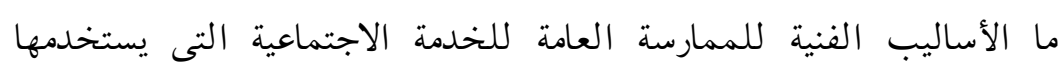

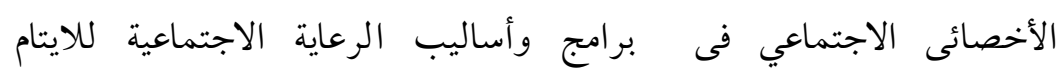

$$
\text { بالمؤسسات الايوائية ؟ الاخصن. }
$$

ب-ما الرؤية المستقبلية لاسهامات الممارسة العامة للخدمة الاجتماعية فى تفعيل برامج

$$
\text { واساليب الرعاية الاجتماعية للايتام بالمؤسسات الايوائية ؟ }
$$

خامساً: مفاهيم الدراسة واطارها النظرى : 


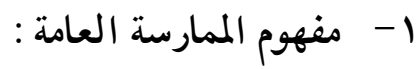

عرفت الممارسة العامة على إنها " اتجاه تطبيقى للخدمة الاجتماعية يتعامل مع كافة

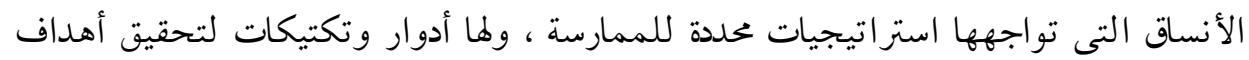

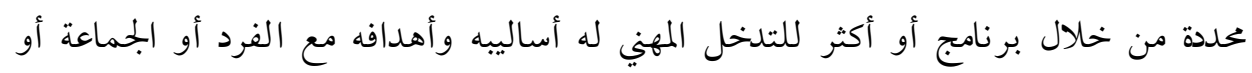

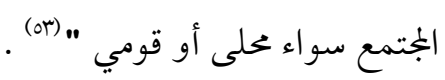

وقد عرفت الممارسة العامة على أنها " قدرة الأخصائى الاجتماعي على استخدام أنسب الاستراتيجيات والوسائل والأساليب لحل مشكلات كافة الانساق التى يتعامل معها سواء

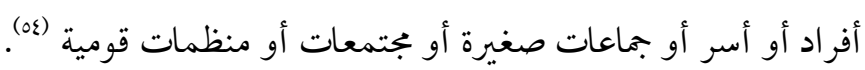
كما عرفت على أنها " الإطار الذى يوفر للأخصائى الاجتماعي أساساً نظريا انتقائيا للممارسة المهنية حيث يتناول التغيير البناء لكل مستويات الممارسة (من الفرد حتى الجتمع)، وتتمثل المسئولية الرئيسية للممارسة العامة فى توجيه وتنمية التغيير المخطط أو عملية حل المشكلة Change كما عرفت على أنها " استخدام وتوظيف قاعدة من المعلومات والقيم المهنية وبجموعة عريضة من المهارات لتحقيق التغيير مع خختلف الأنساق التى يتعامل معها الأخصائى الاجتماعي أثناء أداءه لأدواره المهنية (هo). وقد عرفت على أنها " الاختيار الحر لنماذج ونظريات التدخل المهني والاعتماد على إطار نظرى متعلد يركز على النسق المراد تغييره سواء كان نسق العميل أو أي أنساق أخرى ،

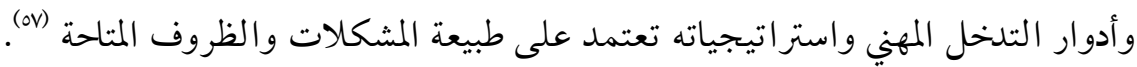
كما عرفت بأنها " الممارسة المهنية التى يركز فيها الممارس العام فى الخدمة الاجتماعية على استخدام الأنساق البيئية والأساليب والطرق الفنية لحل المشكلة دون تفضيل التركيز على تطبيق طريقة من طرق مهنة الخدمة الاجتماعية لمساعدة المستفيدين من خدمات المؤسسات

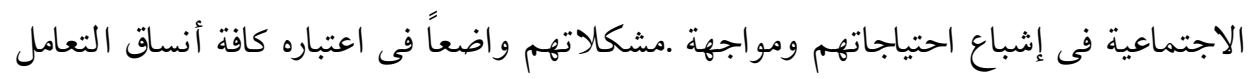

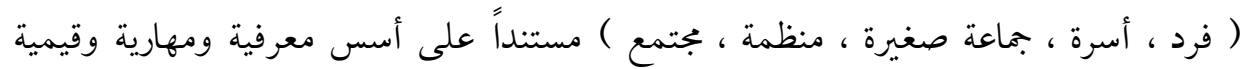
تعكس الطبيعة المنفردة للممارسة المهنية فى تعاملها مع التخصصات الأخرى لتحقيق

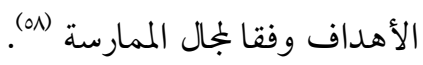


وقد عرف بجلس تعليم الخدمة الاجتماعية الممارسة العامة على أنها " أسلوب من خلاله يمارس الاخصائيون الاجتماعيون المنظور العام للممارسة عن طريق استخدام كافة عمليات المساعلة لتحسين حياة العميل من خلال مساعدته على تحديد مشكلاته وتقدير قدراته وامكاناته ومواطن القوة لديه مع التزامهم بالتقديرات الشاملة والتخطيط للتدخل المهني لمساعدته على تحقيق أهدافه (09). وتقصد الدراسة بالممارسة العامة للخدمة الاجتماعية بأنها " كل ما يمكن أن تسهم به

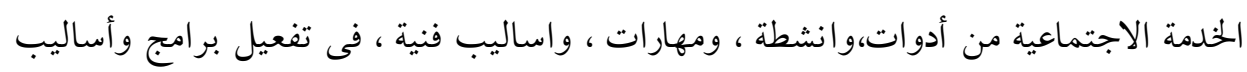
الرعاية الاجتماعية للايتام بالمؤسسات الايوئية .

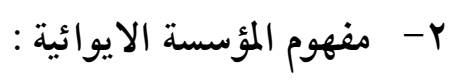

لقد عرفت المؤسسة الايوائية على أنها " دار لايواء الأطفال المعرضين للانحراف بسبب المبه

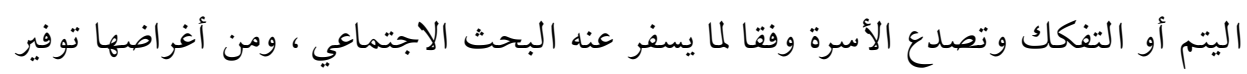
أوجه الرعاية الاجتماعية المختلفة لهؤلاء الأطفال (·). كما عرفت على أنها " دار مجهزة للإقامة الداخلية لايواء الأطفال الخرومين من الرعاية الرعاية الأسرية بسبب الظروف الأسرية الصعبة النى تمنع استمرار معيشتهم داخل أسرهم الطبيعية

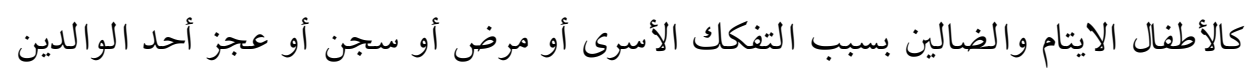

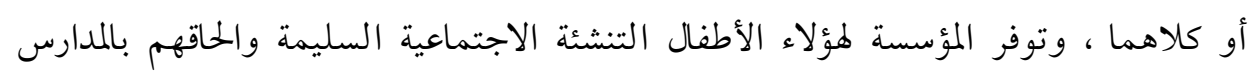

$$
\text { و تدريبهم مهنيا داخل ورش المؤسسة (آ. }
$$$$
\text { يككن تحديد أهداف المؤسسات الايوائية فى جانبين هما : }
$$

الجانب الأول : اتخاذ الاجراءات الوقائية وذلك بهدف شمول الأطفال بالرعاية السليمة . الجانب الثاني : جانب تنموي ويتمثل فى اكساب الطفل كافة القيم التى تنمي شخصيته مثل حب الناس ، التعاون ،تحمل المسئولية ، القدرة على القيادة والتبعية ، الانتماء والولاء

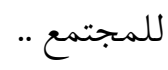
فلسفة الرعاية بالمؤسسات الايوائية (r)": 
- لا يوجد ما يعوض الطفل عن أسرته وانه مادامت الروابط والمقومات الأساسية التى يقوم

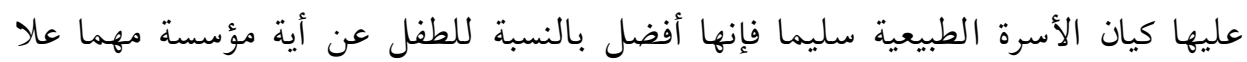
مستواها فالحياة فى جو أسرى تعتبر من أهم حلجات الطفل الأساسية .

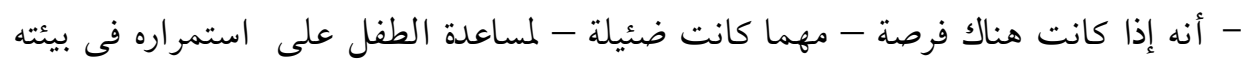

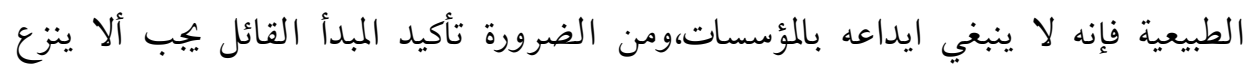
الطفل من أسرته بسبب الفقر فحسب وعلى هذا فإنه كمبدأ عام يجب عدم ايداع الأطفال بالمؤسسات إلا للضرورة القصوى .

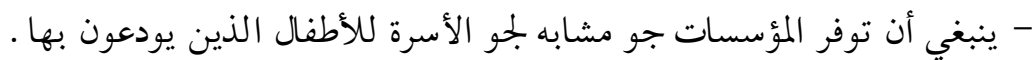
أهمية المؤسسات الايوائية: تتضح أهمية المؤسسات الايوائية إذا فشلت الأسرة الطبيعية أو حدثت ظروف أخرى

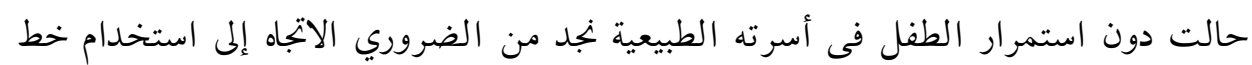

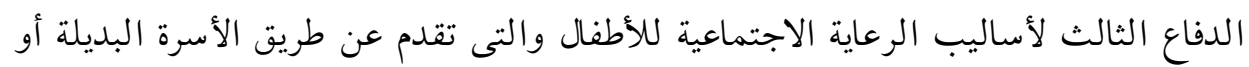
المؤسسات الايوائية (18) برامج الرعاية التى تقدمها المؤسسات الايوائية : تتنوع وتتعدد برامج وأساليب الرعاية التى تقدمها المؤسسات الايوائية لأبنائها . - البرامج الاجتماعية : وهي تهدف إلى تنمية المهارات الاجتماعية لدي الأعضاء من خلال اللقاءات والندوات والرحلات والمعسكرات وحفلات السمر ما يساهم فى تدعيم وترابط الأطفال بالمؤسسة (10) . كما أنها تنمي شخصية الطفل وتكسبه خصائصه النفسية (Tr). - البرامج الثقافية : وتعد وسيلة أساسية في توفير الفرص لحرية التعيير عن الرأي والتعرف على وجهات النظر المختلفة، بالاضافة إلى اشباع حاجات الاعضاء نحو حب تبريب الاستطلاع (TV).كما قد تهدف هذه البرامج إلى تعميق وعي الطفل بقيمته الذاتية وأهميته الاجتماعية (1) (1) - البرامج التعليمية : وهي تسعي إلى تنمية المهارات العقلية والفكرية لدي الأطفال وتزويدهم بالمعلومات الأساسية والتى تناسب مستواهم العقلى (19). 
- البرامج الصحية : وهي تهدف إلى تكوين المواطن الصالح السليم الجسم والنفس والخالى من الأمراض، ويصبح قادراً على المساهمة الايجابية فى العمل والانتاج (vل). - البرامج الرياضية : وهي تهدف إلى تنمية القدرات الجسمية واشباع الحاجات البدنية وتنشئة الأطفال تنشئة صحيحه واكسابهم الروح الرياضية كالتعاون والمنافسة الشريقة واحترام

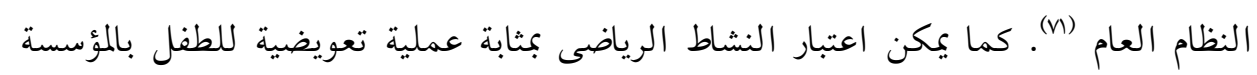

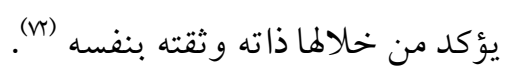
- البرامج الفنية : تعتبر البرامج الفنية وسيلة فى التعبير عن هوايات الاعضاء وميولم وخبراتهم وهي تهدف إلى اكساب الاعضاء الاحساس بالجمال البيئى كذلك اكسابهم قدرة

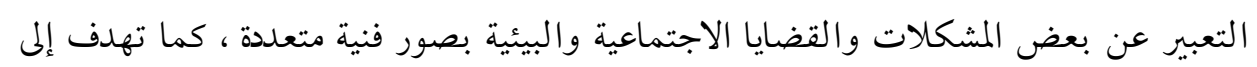
اكتشاف وتنمية القدرات والمواهب والمهارات لدي الأطفال ('Nئ. سادساً: الاجراءات المنهجية للدراسة ونئه العرات والبهات إسة

تدخل هذه الدراسة تحت تصنيف الدراسات الوصفية التحليلية حيث تهدف إلى تحديد واقع استخدام الأخصائيين الاجتماعيين للممارسة العامة للخدمة الاجتماعية فى برامج

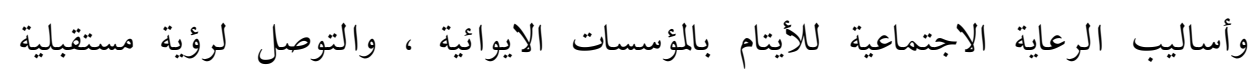
للممارسة العامة فى تفعيل برامج وأساليب الرعاية الاجتماعية للأيتام بالمؤسسات الايوائية .

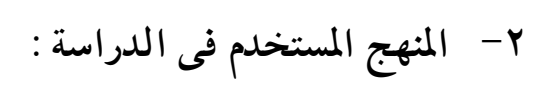
المنهج المستخدم فى الدراسة هو المسح الاجتماعي الشامل لكل الاخصائيين الاجتماعيين العاملين بمؤسسات رعاية الايتام بمحافظة الدقهلية .

$$
\begin{aligned}
& \text { r- أدوات الدراسة : } \\
& \text { أعتمدت الدراسة على : }
\end{aligned}
$$


مقياس لقياس واقع استخدام الأخصائى الاجتماعي للممارسة العامة للخدمة الاجتماعية

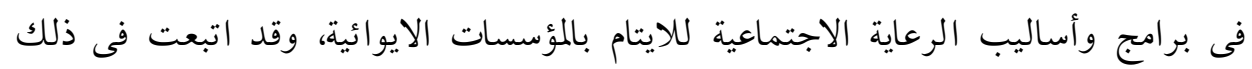
الخطوات التالية فى اعداد المقياس : - تحديد أبعاد المقياس وفقا لأهداف الدراسة وتساؤلاتها ، حيث جاء المقدياس كادل كالآتي : - الجزء الأول : واشتمل على البيانات الأولية للأخصائيين الاجتماعيين "ججتمع الدراسة " .

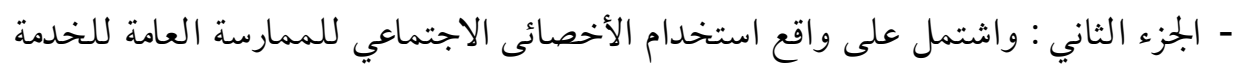

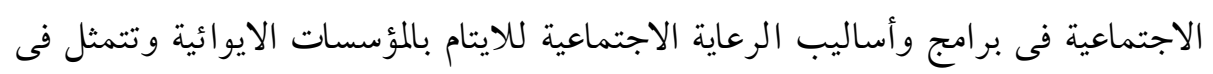

ا-أدوات الممارسة العامة التى يستخدمها الأخصائى الاجتماعي فى برامج وأساليب الرعاية الاجتماعية للايتام بالمؤسسات الايوائية .

r-أنشطة الممارسة العامة التى يستخدمها الأخصائى الاجتماعي فى برامج وأساليب الرعاية الاجتماعية للايتام بالمؤسسات الايوائية .

ب-مهارات الممارسة العامة التى يستخدمها الأخصائى الاجتماعي فى برامج وأساليب الرعاية

$$
\text { الاجتماعية للايتام بالمؤسسات الايوائية . }
$$

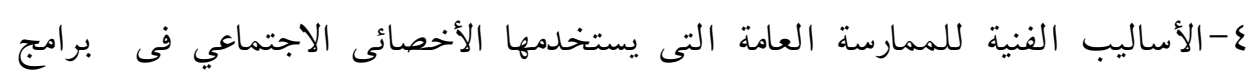

$$
\text { وأساليب الرعاية الاجتماعية للايتام بالمؤسسات الايوائية . }
$$

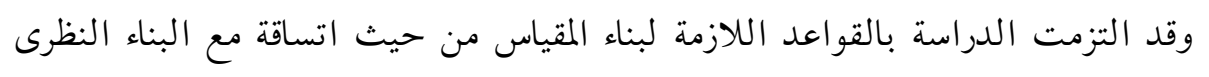

$$
\text { والمنهجي للدراسة . }
$$

$$
\text { اجراءات صدق وثبات المقياس : }
$$

صدق المقياس : وقد تحقق ذلك من خلال الصدق الظاهري ، وذلك بعرض المقياس فى صورته المبدئية على (^) من السادة أعضاء هيئة التدريس بكليات ومعاهد الخدمة الاجتماعية

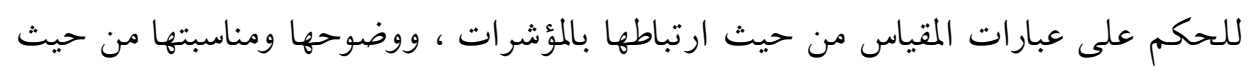

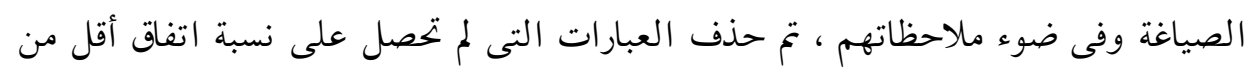
•^^ ، كما تم اضافة بعض العبارات وصياغة البعض الآخر ، ليصبح المقياس فى صورته 
النهائية (1) ) عبارة ، كما تحقق صدق المقياس أيضا من خلال الصدق الذاتي الصلق الاحصائى ، عن طريق حساب الجزر التربيعي لمعامل ثبات المقياس ووجد أنه يساوي (سهو,·)،

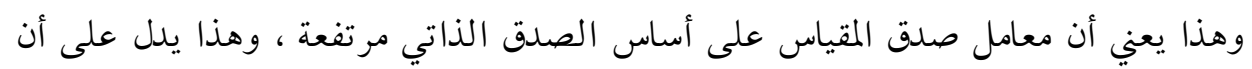
المقياس صادق ويقيس فعلا ما وضع لأجله . ثبات المقياس : وقد اعتمدت الدراسة فى حساب الثبات على طريقة اعادة الاختبار ، حيث تم تطبيق المقياس على عينة عددها (.1 ) من مفردات البحث ثم اعيد تطبيقه مره أخرى بعد (.1) أيام على نفس الجمموعة ، وكان معامل الثبات على المقياس ككل ومؤشراته باستخدام

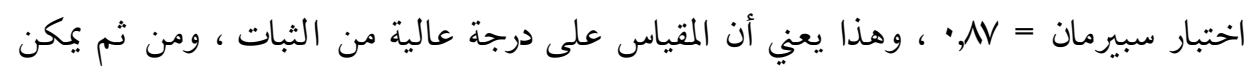
قبول الأداة لجمع البيانات ، حيث أنها تعطي نتائج مستقرة ومتسقه مع كلا الاختبارين . طريقة تصحيح المقياس : قامت الباحثة بوضع تدرج ثلاثى بحيث يكون الاستجابة لكل عبارة هي : ( موافق ثلاث درجات ) ، ( موافق إلى حد ما درجنان ) ، (لا أوافق درجة واحلة) وقد تم تحديد المستوي كما يلى :

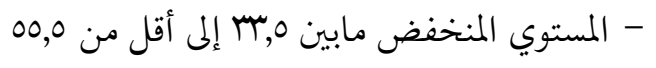

$$
\begin{aligned}
& \text { - المستوي المتوسط مابين 00,0 إلى أقل من W,V }
\end{aligned}
$$

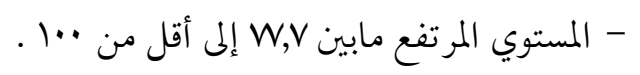

$$
\begin{aligned}
& \text { ع- - مجالات الدراسة : }
\end{aligned}
$$

ا-الجال المكاني : تم تحديد الججال المكاني للدراسة فى مؤسسات رعاية الايتام بمحافظة الدقهلية والتى يعمل بها أخصائيين اجتماعيين وعددها ب Tؤسسة .

ץ-الجمال البشرى : طبقة الدراسة على جميع الاخصائيين الاجتماعيين العاملين بمؤسسات رعاية الايتام بمحافظة الدقهلية وقد بلغ عددهم (YN ) أخصائى .

r-البجال الزمني : وهي فترة جمع البيانات من الميدان،وتحددت فى شهرى مارس وإبريل 10•r. 
口ابعاً : نتائج الدراسة الميدانية :

\section{口(أ) النتائج المرتبطة بالخصائص المميزة لجتمع البحث}

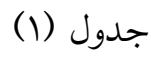

يوضح خصائص مجتمع البحث ( الجال البشرى للدراسة ن = Y )

\begin{tabular}{|c|c|c|c|c|c|c|c|}
\hline$\%$ & 5) & البيان & المتغير & $\%$ & 5) & البيان & المتغبر \\
\hline$\varepsilon r, q$ & ir & - & الخصول على دورات & $\varepsilon 7, \varepsilon$ & r & 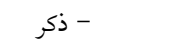 & 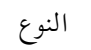 \\
\hline$o v, 1$ & 17 & $y-$ & تدريبية & or, & 10 & - & \\
\hline$\% 1 \ldots$ & ru & \multicolumn{2}{|c|}{ الجموع } & $\wedge_{1} \ldots$ & r & \multicolumn{2}{|c|}{ الجموع } \\
\hline $\mathrm{IV}, \mathrm{V}$ & 0 & - لم يتزوج & الحالة الاجتماعية & $v, 1$ & r & \multicolumn{2}{|r|}{ الس. } \\
\hline $7 \varepsilon, \Gamma$ & 11 & - متزوج & & $I V, \Lambda$ & 0 & $r \cdot-$ & \\
\hline $\mid \xi, \Gamma$ & $\varepsilon$ & - أرمل & & $\mid \varepsilon, \Gamma$ & $\varepsilon$ & ro- & \\
\hline \multirow[t]{2}{*}{$r, v$} & 1 & - مطلق & & rI,O & 7 & $\xi \cdot-$ & \\
\hline & & & & $r q, r$ & 11 & - 0ع فأكثر & \\
\hline \multirow[t]{7}{*}{$\wedge_{1} \ldots$} & rA & & الجمو = & $\% 1 \cdots$ & 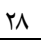 & \multicolumn{2}{|c|}{ المجموع } \\
\hline & & & & $7 \cdot, \mathrm{V}$ & IV & - بكالوريوس & المؤهل \\
\hline & & & & & & خلدة اجتماعية & الدراسى \\
\hline & & & & $M, 1$ & 9 & - دبلوم متوسط & \\
\hline & & & & $V, r$ & r & - ماجستير & \\
\hline & & & & - & - & - دكتوراه & \\
\hline & & & & $\wedge_{1} \ldots$ & YA & \multicolumn{2}{|c|}{ الجموع } \\
\hline
\end{tabular}

[ـوباستقراء بيانات الجدول رقم (1) حول الخصائص المميزة لجتمع البحث يتضح ما يلى : 1- بالنسبة للنوع : يتضح من الجدول أن نسبة §,7؟٪ من مجتمع البحث من الذكور بينما تمثل

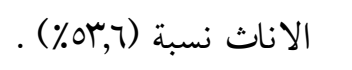

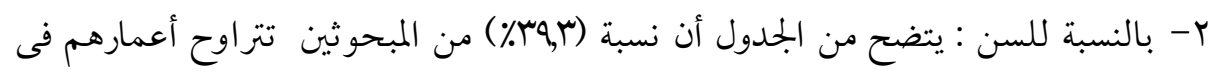

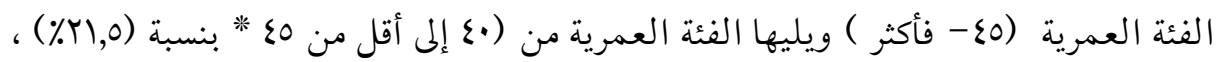

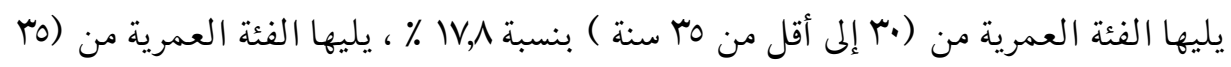

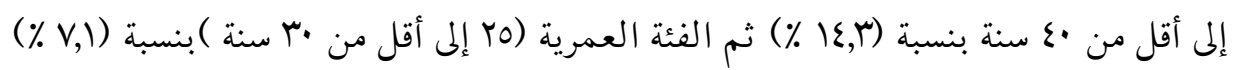


ץ- بالنسبة للحالة الاجتماعيـة : يتضـح مـن الجــدول أن النسـبة العظمـي مـن الأخصـائيين

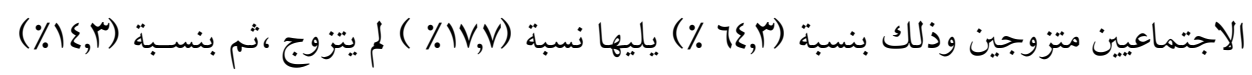

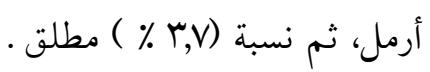

ع- بالنسبة للمؤهل الدراسـى : يتضـح مـن الجــدول أن النسـبة العظمـي مـن الأخصـائيين

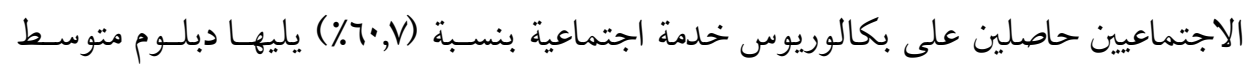

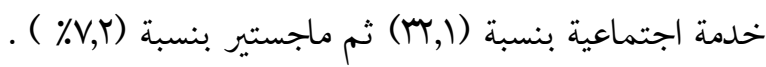

0- بالنسبة للحصول على دورات تدريبية : جاءت نسبة (ه, ؟؟ ٪) نعم لمن حصلو على دورات

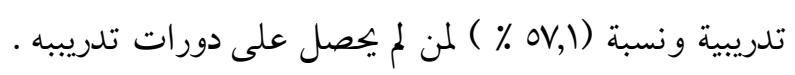

口ب- النتائج المرتبطة بالاجابة على تساؤلات الدراسة :

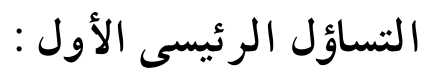

ا-ما واقع استخدام الأخصائى الاجتماعي للممارسة العامة للخدمة الاجتماعية فى برامج

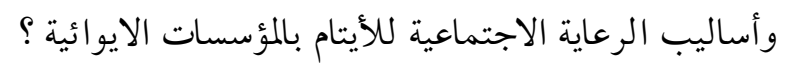
ويتحقق هذا التساؤل بالاجابة على التساؤلات الفرعية التالية :

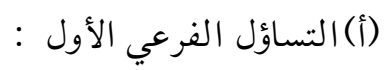

ما أدوات الممارسة العامة التى يستخدمها الاخصائى الاجتماعي فى برامج وأساليب الرعاية الاجتماعية للأيتام بالمؤسسات الايوائية ؟ ويكن الاجابة على هذا التساؤل من خلال

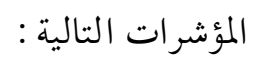




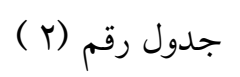

يوضح المتوسط المرجح والنسبة التقديرية لدرجات المبحوثين فى عبارات مؤشر المناقشة

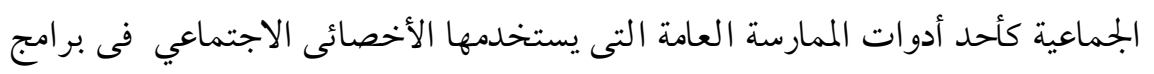

الرعاية الاجتماعية للايتام بالمؤسسات الايوائية.

\begin{tabular}{|c|c|c|c|c|c|c|c|c|}
\hline \multirow[b]{2}{*}{ 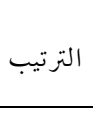 } & \multirow{2}{*}{ 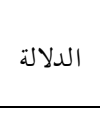 } & \multirow{2}{*}{ 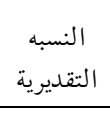 } & \multirow{2}{*}{ 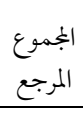 } & \multicolumn{3}{|c|}{ الاستجابات } & \multirow[b]{2}{*}{ العبارات } & \multirow[t]{2}{*}{ p } \\
\hline & & & & ل & 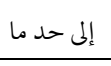 & نعم & & \\
\hline r & منخفض & $0\}, \Lambda$ & $\varepsilon 7$ & IV & $\varepsilon$ & $\checkmark$ & أحرص على تعليم اليتيم أدب الحوار والاستماع إلى & 1 \\
\hline 1 & 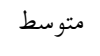 & 00,9 & $\varepsilon V$ & 17 & 0 & $\checkmark$ & أساعد اليتيم للتعبير عن آرائه بحرية وايجابية & r \\
\hline$\varepsilon$ & منخفض & or,\& & $\varepsilon \varepsilon$ & 11 & $\varepsilon$ & 7 & 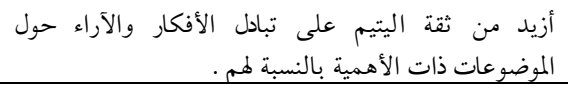 & $r$ \\
\hline r & منخفض & or,7 & £o & IV & $\circ$ & 7 & مشكلاته . من ثقة اليتيم فى نفسه وفى قدرته على عرض & $\varepsilon$ \\
\hline r & منخفض & $\bullet \varepsilon, \Lambda$ & $\sum 7$ & 17 & 7 & 7 & ببعضهم البعض لتحقيق درجة عالية من التواصل الجماعي بين الأيتام & 0 \\
\hline r & منخفض & r, & £o & IV & $\circ$ & 7 & ألقوم بتدريب الأيتام على الأسلوب الديمقراطي فى عرض & 7 \\
\hline \multirow[t]{2}{*}{$\varepsilon$} & منخفض & or,\& & $\varepsilon \varepsilon$ & M & $\varepsilon$ & 7 & مناسبة لها. الفرصة للأيتام لمناقشة مشكلاتهم والوصول لحلول & $\checkmark$ \\
\hline & & & MV & 119 & $\pi$ & $\varepsilon \varepsilon$ & 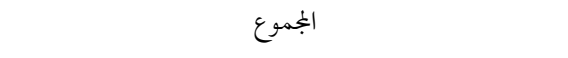 & \\
\hline \multicolumn{7}{|c|}{ النسبة التقديرية = q,هor منخفضة } & المتوسط المرجح العام = 1,7 & \\
\hline
\end{tabular}

يوضح الجدول رقم (Y) استجابات المبحوثين من الأخصائيين الاجتماعيين " مجتمع الدراسة "

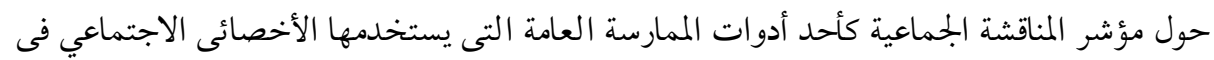

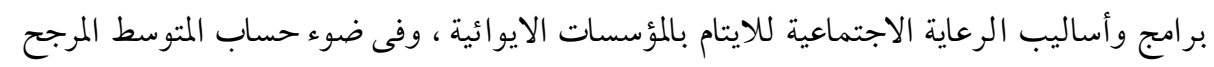

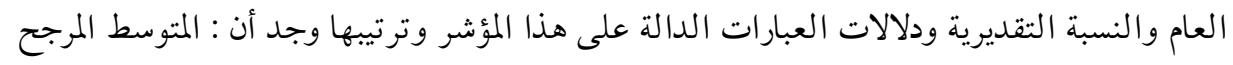

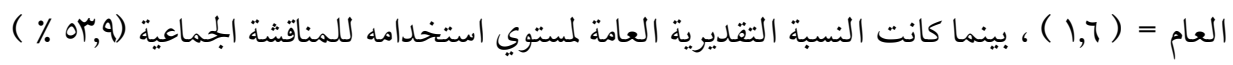

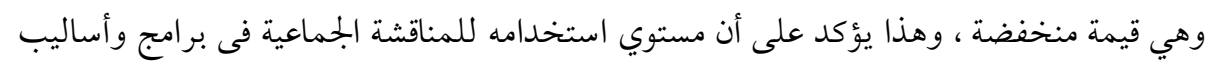

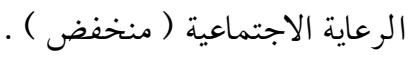


وبمقارنة المتوسط المرجح والنسبة التقديرية لاستجابات الأخصائيين الاجتماعيين فى عبارات مؤشر

المناقشة الجماعية وجد أنها تتوزع توزيعا احصائيا فى مستويين حسب الأهمية كالتالى :

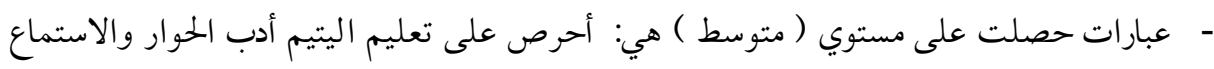

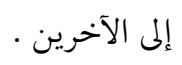

- عبارات حصلت على مستوي ( منخفض ) ومرتبه كالتالى : اسعي لتحقيق درجة عالية من

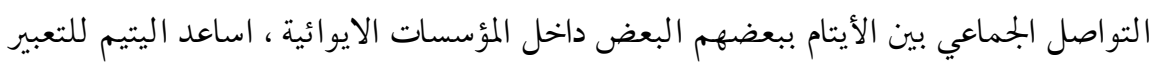

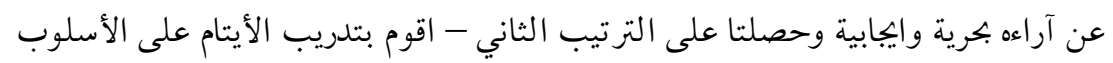

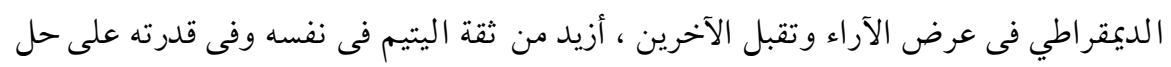

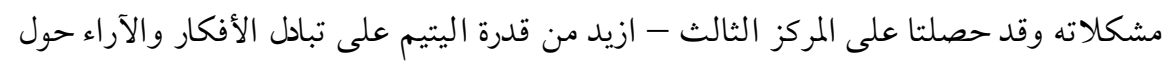

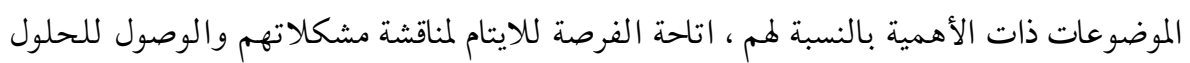

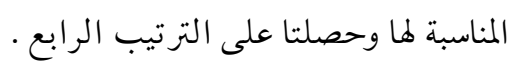
r- ب المؤشر الثاني : الندوات :

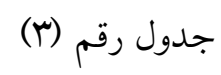

يوضح المتوسط المرجح والنسبة التقديرية لدرجات المبحوثين فى عبارات مؤشر الندوات كأحد رلد أدوات الممارسة العامة التى يستخدمها الأخصائى الاجتماعي فى برامج الرعاية المقدمه للايتام بالمؤسسات الايوائية.

\begin{tabular}{|c|c|c|c|c|c|c|c|c|}
\hline \multirow{2}{*}{ الترتيب } & \multirow{2}{*}{ 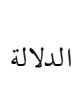 } & \multirow{2}{*}{ 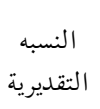 } & \multirow{2}{*}{ 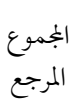 } & \multicolumn{3}{|c|}{ الاستجابات } & \multirow{2}{*}{ 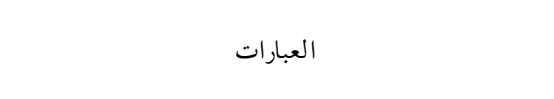 } & \multirow[b]{2}{*}{$p$} \\
\hline & & & & ע & 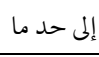 & نعم & & \\
\hline r & 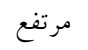 & $9 \pi, 9$ & $\mathrm{va}$ & r & r & $r \varepsilon$ & إكسب الأيتام معارف سياسية ، اجتماعية ، دينية & 1 \\
\hline r & 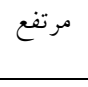 & $\Lambda r, 1$ & 79 & v & 1 & r. & وأتيح ل للأيتام خبرات متنوعة لأشـخاص غختلفين فى وقت & r \\
\hline$\varepsilon$ & 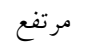 & vq,1 & TV & $v$ & r & M & أحرص على تثقيف الأيتام حول العديد من الموضوعات . & r \\
\hline$\varepsilon$ & 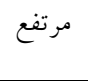 & $v q, 1$ & TV & 7 & $\circ$ & IV & هادفة على تعديل أفكار ومعتقدات الأيتــام السـلبية الغـير & $\varepsilon$ \\
\hline 1 & 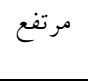 & $90, r$ & $\wedge \cdot$ & 1 & r & ro & هادفة على تعديل أفكار ومعتقدات الايتام السلبية والغـير & 0 \\
\hline o & 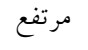 & $0 \xi, \Lambda$ & $\{7$ & IV & $\varepsilon$ & $\mathrm{v}$ & أسعى دائما لغرس حب القراءة والثقافة لدي الأيتام . & 7 \\
\hline & & & & & & & 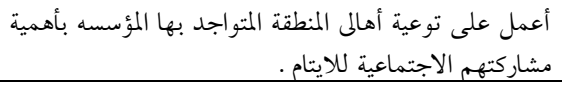 & $v$ \\
\hline
\end{tabular}




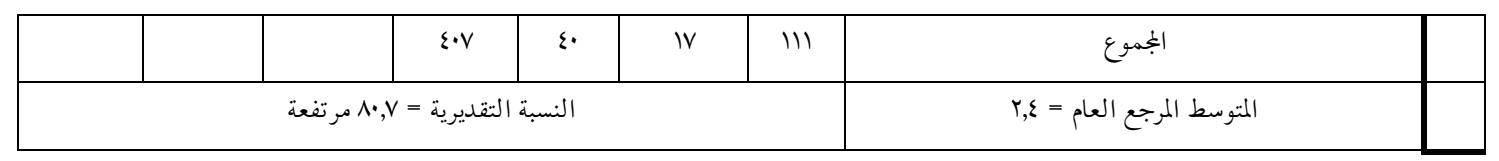

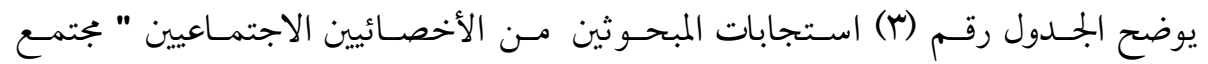

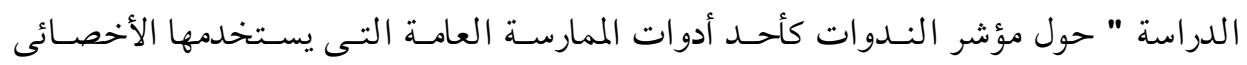

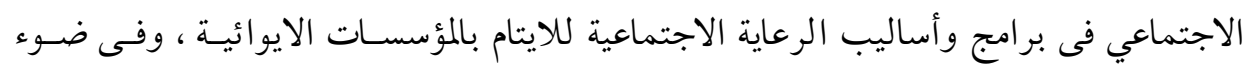

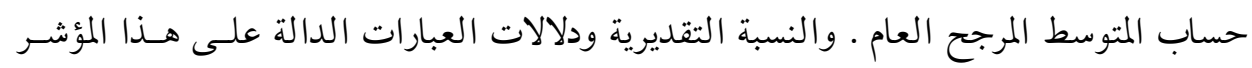

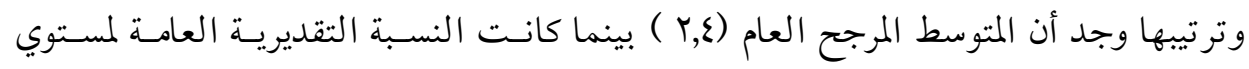

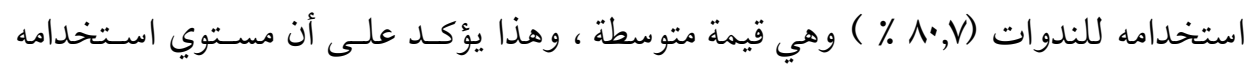

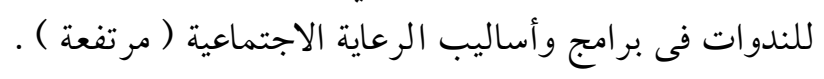

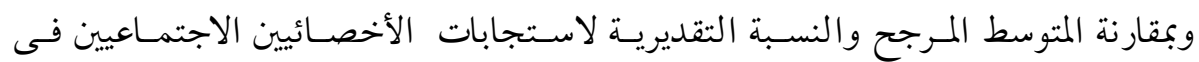

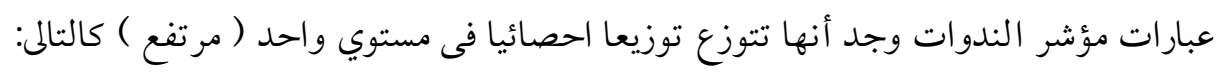

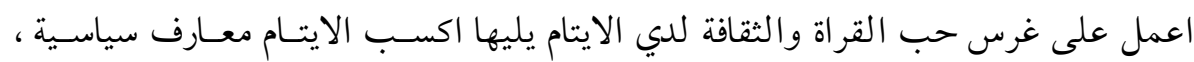

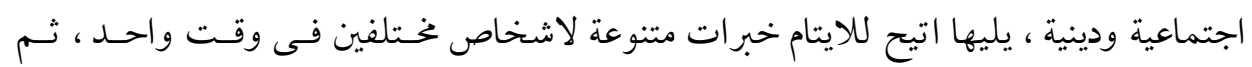

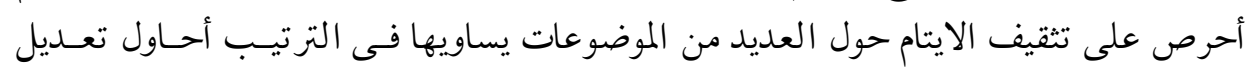

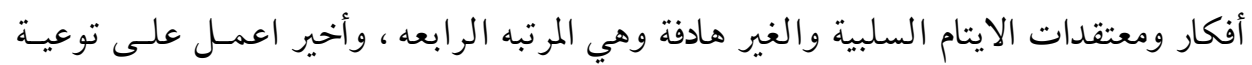

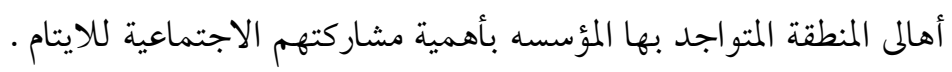

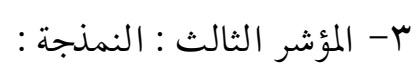

$$
\text { جدول رقم (ع) (ئ) }
$$

يوضح المتوسط المرجح والنسبة التقديرية لدرجات المبحوثين فى عبارت مؤشر النمذجه كأحد

\begin{tabular}{|c|c|c|c|c|c|c|c|c|}
\hline \multirow{2}{*}{ 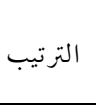 } & \multirow{2}{*}{ الدلالة } & \multirow{2}{*}{ التقديرية } & \multirow{2}{*}{ المرجع } & \multicolumn{3}{|c|}{ الاستجابات } & \multirow{2}{*}{ 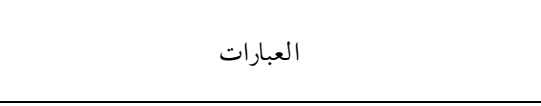 } & \\
\hline & & & & $y$ & إلى حد ما & نعم & & \\
\hline r & متوسط & 00,9 & $\varepsilon v$ & IV & $r$ & $\wedge$ & ألحرص على عرض أفلام هادفة تتعرض لبعض مشكلات & 1 \\
\hline$r$ & منخفض & $0 ., \cdot$ & $\varepsilon r$ & 19 & $r$ & 7 & منها الايتام كما عرضت مناقشت وتحليل بعضلام المشكلات التى يعاني & r \\
\hline 1 & 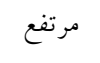 & 每 & $\varepsilon r$ & 17 & 7 & $\circ$ & أقوم بتوعية الأيتام بأساليب وطرق مواجهة مشكلاتهم & $r$ \\
\hline 0 & منخفض & 更 & $\varepsilon r$ & $M$ & 0 & 0 & 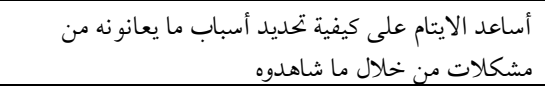 & $\varepsilon$ \\
\hline$\varepsilon$ & منخفض & $\varepsilon V, T$ & $\varepsilon$. & 19 & 7 & $r$ & أحرص على تعويد الأيتام على عادات النظافة والخافظة & 0 \\
\hline
\end{tabular}
أدوات الممارسة العامة التى يستخدمها الاخصائى الاجتماعي فى برامج الرعاية المقدمه للايتام

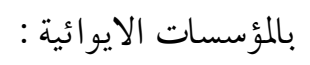




\section{مجلة الخدمة الاجتماعية}

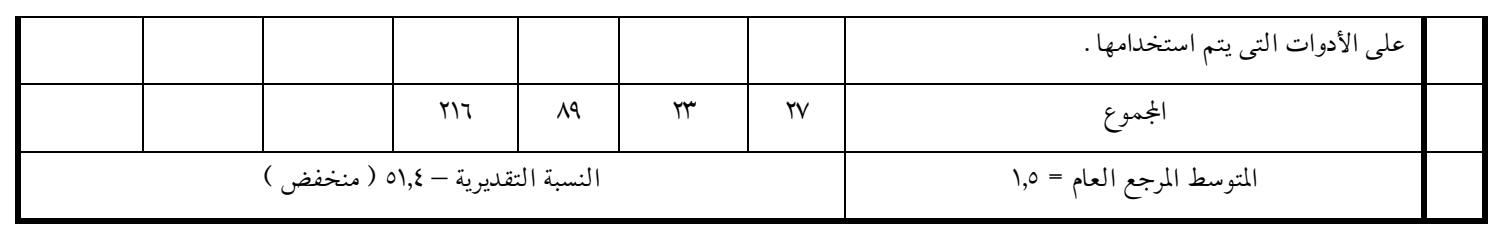

يوضح الجدول (ع) : استجابات المبحوثين من الأخصائيين الاجتماعيين " بجتمع الدراسـة

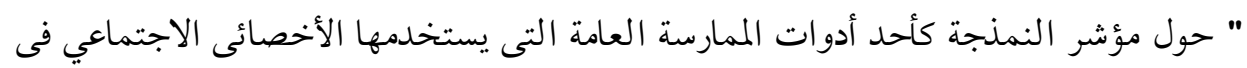

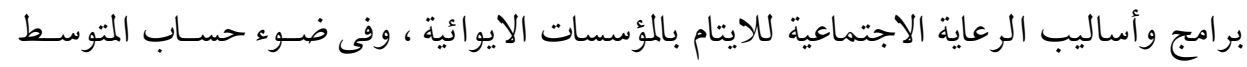

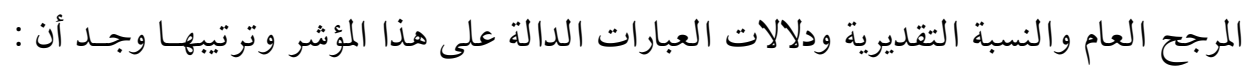
المتوسط المرجح العام (1,0) بينما كانت النسبة التقديرية العامة لمتسـوي اسـتخدامه للنمذجـهـ

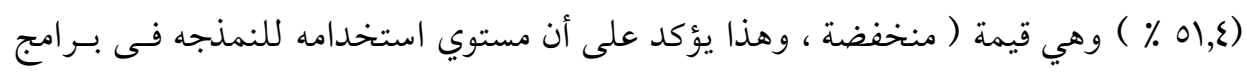
وأساليب الرعاية الاجتماعية ( منخفضة ) .

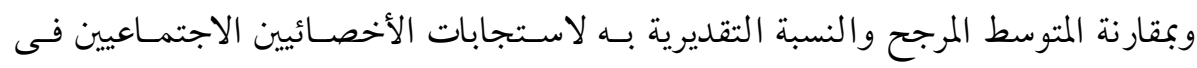
عبارات مؤشر النمذجه وجد أنها تتوزع توزيعا احصائيا فى ثلاث مستويات كالآتي :

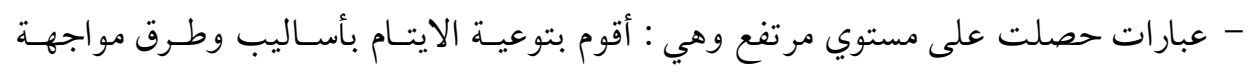
مشكلاتهم . - عبارات حصلت على مستوي متوسط وهي : أحسرص على عـرض أفـلام هادفـة تتعـرض لبعض مشكلات الأطفال بصفة عامة . - عبارات حصلت على مستوي منخفض وهي : اعمل على مناقشة وتحليل بعض المشـكلات التى يعاني منها الايتام كما عرضت بالأفلام ثم أحرص على تعويد الايتام على عادات النظافة والخافظة على الادوات التى يستخدمها . 
ع- المؤشر الرابع : الخحاضرات : (2)

\section{جدول رقم (0 ) - (0)}

يوضح المتوسط المرجع والنسبة التقديرية لدرجات المبحوثين فى عبارات مؤشر الخاضرات

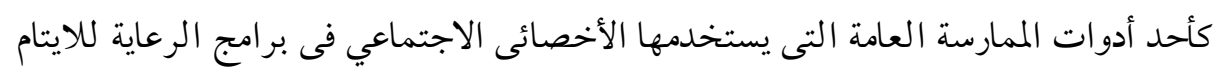

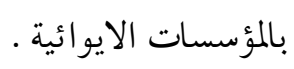

\begin{tabular}{|c|c|c|c|c|c|c|c|c|}
\hline \multirow{2}{*}{ 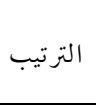 } & \multirow{2}{*}{ 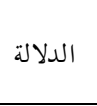 } & \multirow{2}{*}{ النقديرية } & \multirow{2}{*}{ المرجع } & \multicolumn{3}{|c|}{ الاستجابات } & \multirow{2}{*}{ 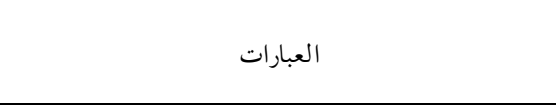 } & \multirow[t]{2}{*}{$p$} \\
\hline & & & & ע & 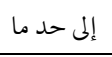 & نعم & & \\
\hline$\circ$ & منخفض & or,r & $£ \varepsilon$ & 19 & r & $\mathrm{v}$ & أقوم بتدريب الايتام على الاسعافات الأولية & 1 \\
\hline r & 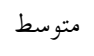 & $7 \cdot, \mathrm{V}$ & 01 & 10 & r & 1. & أعمل على تنمية الوعي الصحي للاينام & r \\
\hline r & 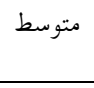 & $\pi$, & or & is & r & 11 & أمراض . بتبصير الايتام بأخطار التلوث البيئى وما يسبب مـن & 1 \\
\hline$\varepsilon$ & 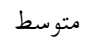 & $\Delta 9,0$ & $\circ$. & 17 & r & 1. & أحرص على تعويد الايتام على السلوك الصحي السليم . & $\varepsilon$ \\
\hline r & 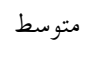 & $7 \cdot, \mathrm{V}$ & 01 & 10 & r & 1. & اقوم بتبصير الايتام بطرق الوقاية من الأمراض & $\circ$ \\
\hline \multirow[t]{2}{*}{1} & 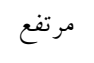 & $\Lambda \leqslant, 0$ & n & $\varepsilon$ & $\circ$ & 19 & أقوم بتبصير الايتام بأهمية مشاركتهم فى برامج المؤسسة & 4 \\
\hline & & & $\pi$. & $\Lambda$ & M & TV & 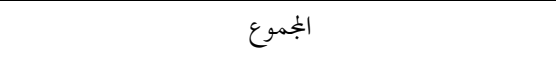 & \\
\hline \multicolumn{7}{|c|}{ النسبة التقديرية = م,با متوسط } & المتوسط المرجح العام = 1,4 & \\
\hline
\end{tabular}

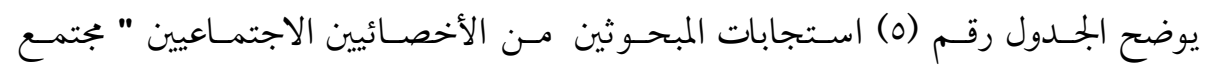

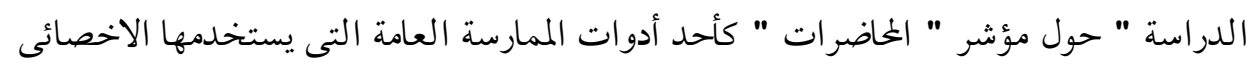

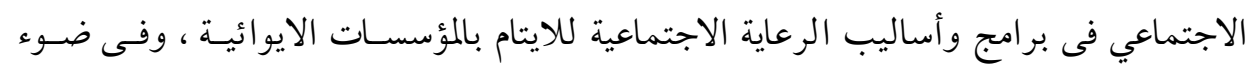

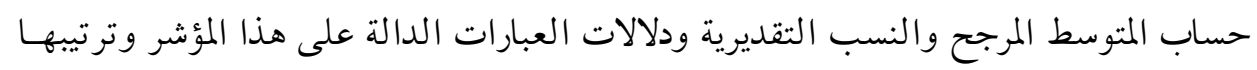
وجد أن : المتوسط المرجح العام (1,9 ) ، بينما كانت النسبة التقديرية العامة لمستوي استخدامه ودهي

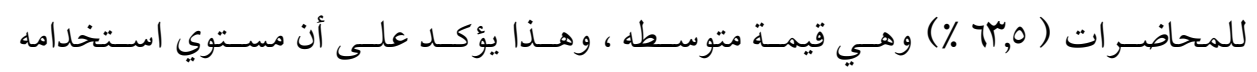

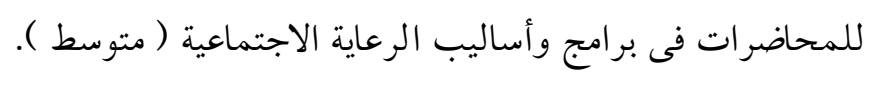


وبمقارنة المتوسط المـرجح والنسـبة التقديريـة لاسـتجابات الأخصـائيين الاجتمـاعيين فى عبارت مؤشر الخاضرات وجد أنها تتوزع توزيعا احصائيا فى مستويين حسب الأهمية كالتالى: - عبارات حصلت على مستوي ( مرتفع ) وهي : أقوم بتبصير الايتام بأهميـة مشـاركتهم في تصني برامج الرعاية المقدمة بالمؤسسه . - عبارات حصلت على مستوي متوسط وهي : أقوم بتبصير الايتام بأخطار التلوث البيئى وما

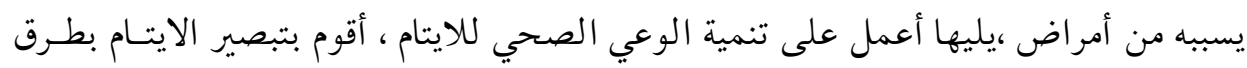

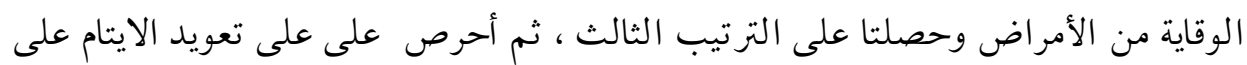

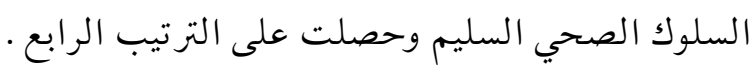
- عبارات حصلت على مستوي منخفض وهي : أقوم بتدريب الايتام على الاسعافات الأوليـة وقد حصلت على الترتيب الخامس .

$$
\text { حدول رقم (7) }
$$

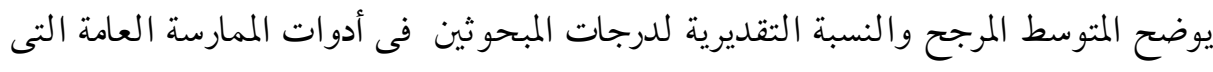
يستخدمها الأخصائى الاجتماعي فى برامج وأساليب الرعاية الاجتماعية للايتام بالمؤسسات الايوائية .

\begin{tabular}{|c|c|c|c|c|c|c|c|c|}
\hline \multirow{2}{*}{ الترتيب } & \multirow{2}{*}{ 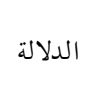 } & \multirow{2}{*}{ التقديرية } & \multirow{2}{*}{ المرجع ع } & \multicolumn{3}{|c|}{ الاستجابات } & \multirow{2}{*}{ الادوات التى يستخدمها الأخصائيين فى برامج وأساليب } & \multirow[t]{2}{*}{$p$} \\
\hline & & & & ע & 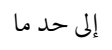 & نعم & & \\
\hline r & منخفض & or,o & MV & 119 & $\pi$ & $\varepsilon \varepsilon$ & المناقشة الجماعية & 1 \\
\hline 1 & مرتفعة مرت & $\wedge \cdot, \mathrm{V}$ & $\varepsilon \cdot v$ & $\varepsilon \cdot$ & IV & 111 & 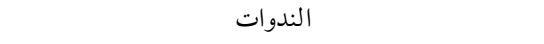 & r \\
\hline$\varepsilon$ & منخفض & $01, \varepsilon$ & rit & 19 & $\pi$ & TV & النمذجه & r \\
\hline r & متوسط & $\pi, 0$ & $\pi$. & $\Lambda$ & $M$ & iV & الخحاضرات & $\varepsilon$ \\
\hline \multicolumn{7}{|c|}{ النسبة التقديرية = T,0 متوسط } & المتوسط العام المرجح = 1,9 & \\
\hline
\end{tabular}

يوضح الجلدول رقم (7) استجابات المبحوثين مسن الأخصـائيين الاجتمـاعيين فيمـا يتعلـق

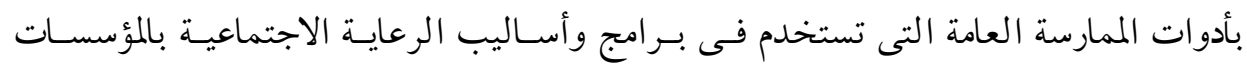
الايو ائية ، وفى ضوء حساب المتوسط المرجح والنسبة التقديريـة ودلالات المؤشـرات الفرعيـة ، وجد أن المتوسط المـرجح العـام (1,9 ) بينمـا النسـبة التقديريـة العامـة لمسـتوي اسـتخدامهم

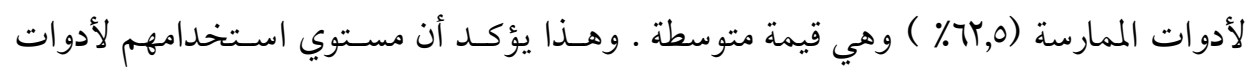


الممارسة العامة ( متوسط ) وبمقارنة المتوسط المرجح والنسب التقـدير لاسـتجابات المبحــوثين وجد أنها وفق الترتيب التالى : التهان

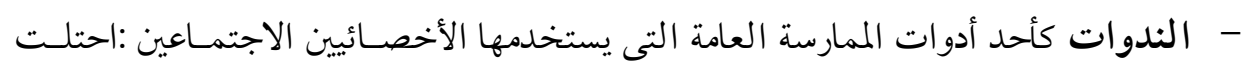

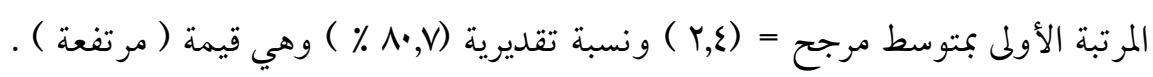
- الحاضرات كأحد أدوات الممارسة العامة التى يستخدمها الأخصائيين الاجتماعيين : احتلت

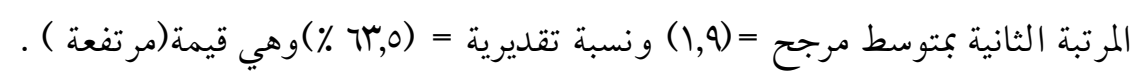

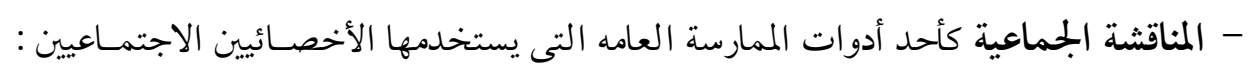

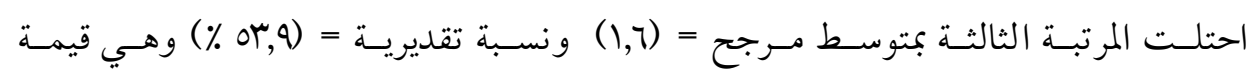
(منخفضة ) (منئ) - النمذجة كأحد ادوات الممارسة العامة التى يستخدمها الأخصائيين الاجتمـاعيين : احتلـت المرتبة الرابعة بمتوسط مرجح (1,0 ) ونسبة تقديرية (§,0 ٪ ) ) وهي قيمة (منخفضة ) . 


$$
\text { : بان (ب) التساؤل الفرعي الثاني }
$$

ما أنشطة الممارسة العامة للخدمة الاجتماعية التى يستخدمها الأخصائى الاجتماعي فى برامج وأساليب الرعاية الاجتماعية للايتام بالمؤسسات الايوائية ؟ ويككن الاجابة على هذا التساؤل

$$
\text { ا- المؤشر الأول : الرحلات المؤشرات التالية . }
$$

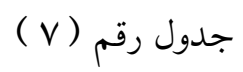

\begin{tabular}{|c|c|c|c|c|c|c|c|c|}
\hline \multirow[b]{2}{*}{ 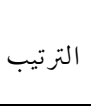 } & \multirow[b]{2}{*}{ الدلالة } & \multirow{2}{*}{ 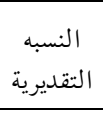 } & \multirow{2}{*}{ 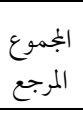 } & \multicolumn{3}{|c|}{ الاستجابات } & \multirow[b]{2}{*}{ 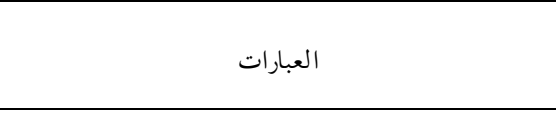 } & \multirow[b]{2}{*}{$p$} \\
\hline & & & & y & إلى حد ما & نعم & & \\
\hline 0 & متوسط & $\mathrm{TV}, \Lambda$ & or & 9 & 9 & 1. & أسعي إلى تكوين علاقات اجتماعية ايجابية بين الأيتام داخل & 1 \\
\hline$\varepsilon$ & متوسط & 79,1 & $\Delta \Lambda$ & 9 & $\wedge$ & 11 & أسعي إلى تكوين علاقات اجتماعية ايجابية بين الأيتام & r \\
\hline$r$ & متوسط & $v \cdot, r$ & 09 & 9 & v & $\pi$ & أساعد الايتام على التعرف بمجتمعهم الخارجي & $r$ \\
\hline 1 & متوسط & $v, r$ & $T \varepsilon$ & ○ & 1. & Ir & احرص على اكتشاف ومعرفة الموارد والامكانيات المناحة & $\varepsilon$ \\
\hline r & متوسط & vo, & זו & 7 & 9 & Ir & أتيح الفرصة للتيم لاكسابه العديد من المعارف والخبرات . & 0 \\
\hline 7 & منخفض & $\varepsilon \Lambda \Lambda$ & $\varepsilon$ & $r$. & $r$ & 0 & أحرص على تكوين معارف وصداقات جديدة للايتام خارج & 7 \\
\hline 1 & متوسط & $v, r$ & $T \varepsilon$ & 0 & 1. & Ir & 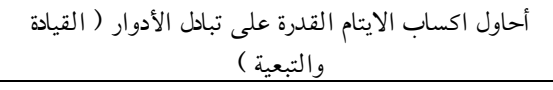 & V \\
\hline 0 & متوسط & $T V, \Lambda$ & ov & 9 & 9 & 1. & أسعي إلى تحقيق أهداف التنشئة الاجتماعية وبناء شخصية & $\wedge$ \\
\hline$\checkmark$ & منخفض & $\varepsilon V, 7$ & $\varepsilon \cdot$ & $r$. & $\varepsilon$ & $\varepsilon$ & 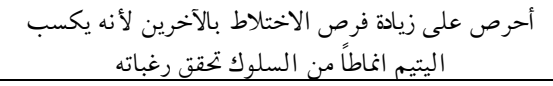 & 9 \\
\hline & & & 0.4 & $9 r$ & 79 & 91 & 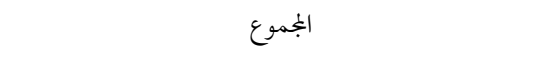 & \\
\hline \multicolumn{7}{|c|}{ النسبة التقديرية = ז, آ7 متوسط } & المتوسط المرجح العام = 1,9 & \\
\hline
\end{tabular}

يوضح المتوسط المرجح والنسبة التقديرية لدرجات المبحوثين فى عبارات مؤشر الرحلات

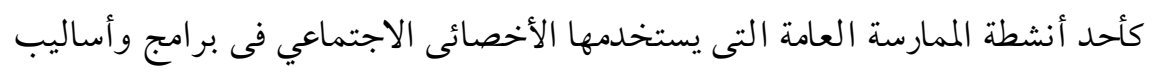
الرعاية للايتام بالمؤسسات الايوائية .

يوضح الجـدول رقـم (V) اسـتجابات المبحــوثين مـن الأخصـائين الاجتمـاعيين " مجتمـع

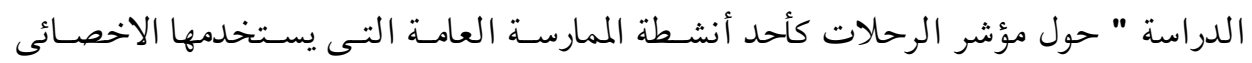

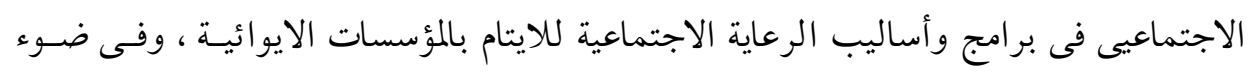


حساب المتوسط المرجح العام والنسبة التقديرية ودلالات العبـارات الدالـة على هـذا المؤشـر

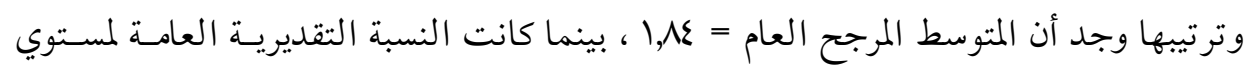

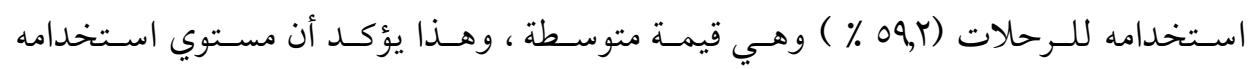
للرحلات فى برامج وأساليب الرعاية الاجتماعية ( متوسط ) .

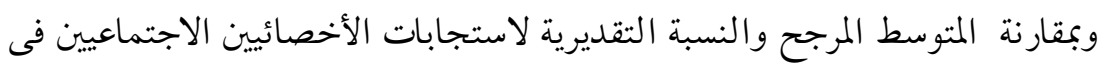

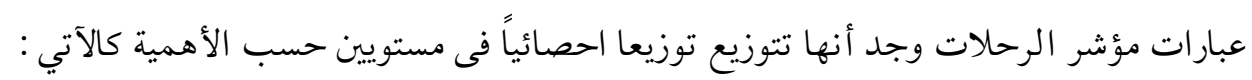
- عبارات حصلت على مستوي ( متوسط ) ومرتبه كالآتي :

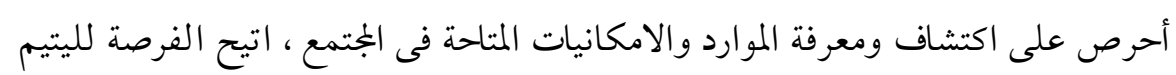
لاكسابه العديد من المعارف والخبرات ، اساعد الايتام على التعرف بمجتمعهم الخارجي ، اسعي

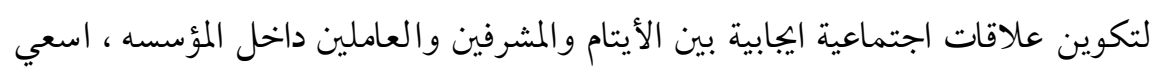
لتكوين علاقات اجتماعية ايجابية بين الايتام داخل المؤسسه . - عبارات حصلت على مستوي ( منخفض ) ومرتبه كالآتي :

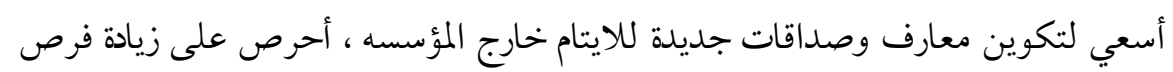
اختلاط الايتام بآخرين لاكسابهم انماطا من السلوك تحقق رغباتهم . 
r- المؤشر الثاني : حفلات السمر :

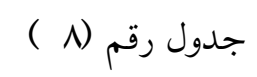

يوضح المتوسط المرجح والنسبة التقديرية لدرجات المبحوثين فى عبارات مؤشر حفلات

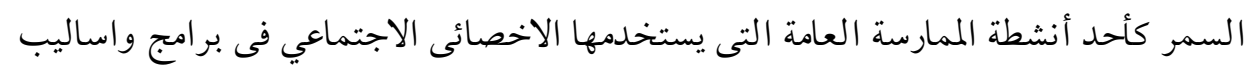
الرعاية للايتام بالمؤسسات الايوائية

\begin{tabular}{|c|c|c|c|c|c|c|c|c|}
\hline \multirow[b]{2}{*}{ 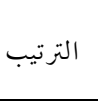 } & \multirow{2}{*}{ 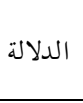 } & \multirow{2}{*}{ 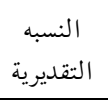 } & \multirow{2}{*}{ 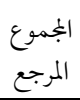 } & \multicolumn{3}{|c|}{ الاستجابات } & \multirow{2}{*}{ العبارات } & \multirow[b]{2}{*}{ p } \\
\hline & & & & $y$ & إلى حد ما & نعم & & \\
\hline r & 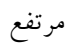 & $97, £$ & $\wedge$ & 1 & 1 & r & أحرص على اشباع هوايات الايتام المتعلدة & 1 \\
\hline$\varepsilon$ & 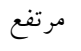 & $\Lambda r, l$ & 79 & V & 1 & r. & أحاول اظهار ذاتية اليتيم وتنمية شخصيته & r \\
\hline r & مرتفع & $90, r$ & $\wedge \cdot$ & 1 & r & ro & داخلِ نفوسهُ لشغل أوقات فراغ الأيتـام فـى جـو يبعـث السـرور & $r$ \\
\hline 0 & مرتفع & VQ, & TV & 7 & $\circ$ & IV & أحاول زياة قوة الروابط والصلات بين الأيتام & $\varepsilon$ \\
\hline 7 & مرتفع & va,o & 77 & $\wedge$ & r & M & 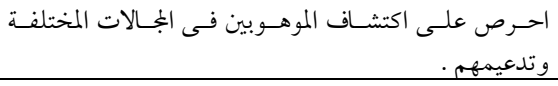 & 0 \\
\hline \multirow[t]{2}{*}{1} & 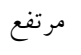 & 91 & $\Lambda$ & - & 1 & TV & أحاول زيادة التقارب بين الأيتام والعاملين بالمؤسسة & 7 \\
\hline & & & $\varepsilon \varepsilon 7$ & & & & 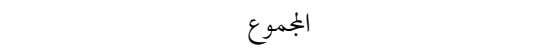 & \\
\hline \multicolumn{7}{|c|}{ النسبة التقديرية - M,O ٪ مرتفع } & المتوسط المرجح العام = r,V & \\
\hline
\end{tabular}

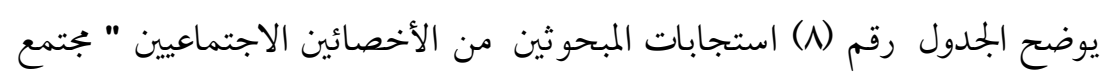

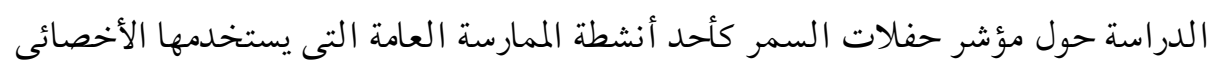
فى برامج وأساليب الرعاية الاجتماعية للايتام بالمؤسسات الايوائية ، وفى ضوء حساب المتوسط المرجح العام والنسبة التقديرية ودلالات العبارات الدالة على هذا المؤشر وترتيبها

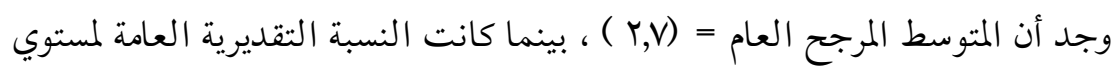
استخدامه للرحلات (M,0) وهي قيمة مرتفعة ، وهذا يؤكد أن مستوي استخدامه لحفلات

$$
\text { السمر فى برامج وأساليب الرعاية الاجتماعية ( مرتفع ) . }
$$

- وبمقار نة المتوسط المرجح والنسبة التقديرية لاستجابات الأخصائيين الاجتماعيين فى عبارات مؤشر حفلات السمر وجد أنها تتوزع توزيعا احصائيا فى مستوي واحد (مرتفع) كالتالى : 
أحاول زيادة التقارب بين الأيتام والعاملين بالمؤسسه ، أحرص على اشباع هوايات الايتام

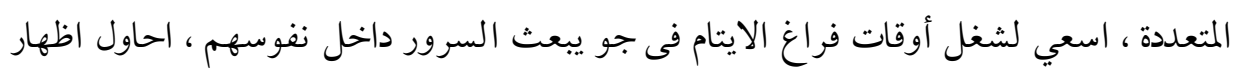

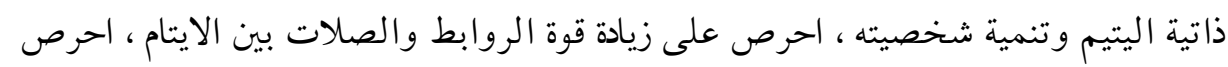
على اكتشاف الموهو بين فى الجالات المختلفة وتدعيمهم .

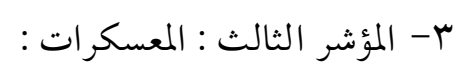

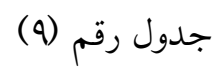

يوضح المتوسط المرجح والنسب التقديرية لدرجات المبحوثين فى عبارات مؤشر المعسكرات كأحد أنشطة الممارسة العامة التى يستخدمها الأخصائى الاجتماعي فى برامج وأساليب الرعاية الاجتماعية للايتام بالمؤسسات الايوائية .

\begin{tabular}{|c|c|c|c|c|c|c|c|c|}
\hline \multirow[b]{2}{*}{ 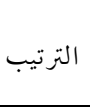 } & \multirow{2}{*}{ الدلالة } & \multirow{2}{*}{ 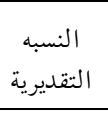 } & \multirow{2}{*}{ 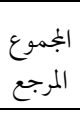 } & \multicolumn{3}{|c|}{ 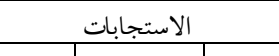 } & \multirow{2}{*}{ 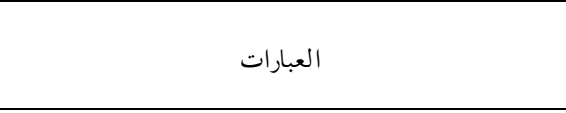 } & \multirow[b]{2}{*}{ p } \\
\hline & & & & y & إلى حد ما & نعم & & \\
\hline 1 & متوسط & $7 \cdot, V$ & 01 & 10 & r & 1. & أحرص على تدعيم قيم الديمقراطية لدي الأيتام & 1 \\
\hline 1 & متوسط & $7 \cdot, V$ & 01 & 10 & $r$ & 1. & أحاول اشباع هوايات الايتام وممارستها & r \\
\hline r & منخفض & or, & so & 11 & $r$ & $\checkmark$ & 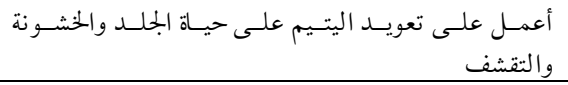 & $r$ \\
\hline r & منخفض & or, & so & 11 & $r$ & $\checkmark$ & الصعي لاكساب اليتيم القدرة على تحمـل المسـئولية وتحمـل & $\varepsilon$ \\
\hline 1 & متوسط & $7 \cdot, V$ & 01 & 10 & $r$ & 1. & وأسعي لاكساب اليتيم خـبرات جماعيـة كالمشــاركة الجماعيـة & 0 \\
\hline \multirow[t]{2}{*}{1} & متوسط & $7 \cdot, V$ & 01 & 10 & r & 1. & 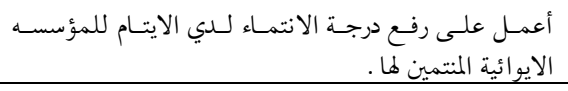 & 7 \\
\hline & & & T৭\& & & & & الجموع & \\
\hline \multicolumn{7}{|c|}{ النسبة التقديرية - r, امه متوسط } & المتوسط المرجح العام = 1,V0 & \\
\hline
\end{tabular}

يوضح الجدول رقم (ه) استجابات المبحوثين من الأخصائين الاجتماعيين " مجتمع البحث

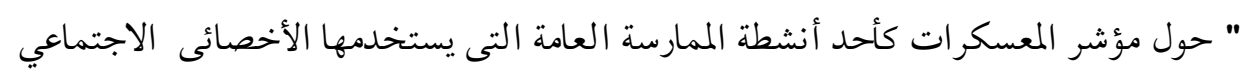

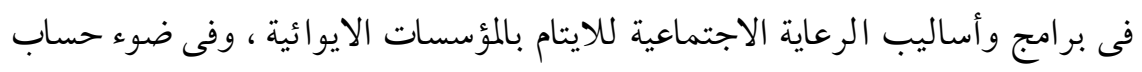
المتوسط المرجح العام والنسبة التقديرية ودلالات العبارات الدالة على هذا المؤشر وترتيبها وجد أن المتوسط المرجح العام = (1,V0) بينما كانت النسبة التقديرية العامة لمستوي ودئ 
استخدامه للمعسكرات ؟بره ٪ وهي قيمة متوسطة ، وهذا يؤكد أن مستوي استخدامه

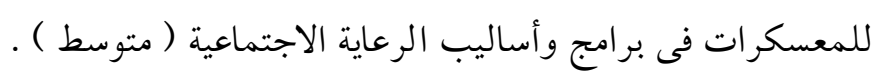

- وبمقارنة المتوسط المرجح والنسبة التقديرية لاستجابات الأخصائيين الاجتماعيين فى عبارات مؤشر الرحلات وجد أنها تتوزع توزيعا احصائيا فى مستويين ومرتبة كالنالى : - عبارات حصلت على مستوي متوسط ومرتبة كالتالى : أحرص على تدعيم قيم الديمقر اطية لدي الايتام ، أحاول اشباع هوايات الايتام ، اسعي مئي

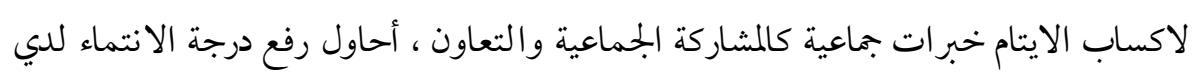
الايتام بالمؤسسه الايوائية المنتمين لها. - عبارات حصلت على مستوي منخفض كالنالى : اجتهد فى تعويد اليتيم على حياة الجلد والخشونة والتقشف ، اسعي لاكساب اليتيم القدرة

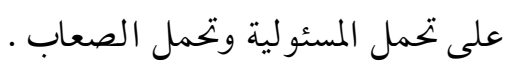


ع- المؤشر الرابع : الخدمة العامة:

\section{جدول رقم (1.) (1)}

يوضح المتوسط المرجح والنسبة التقديرية لدرجات المبحوثين فى عبارات مؤشر الخدمة العامة كأحد أنشطة الممارسة العامة التى يستخدمها الاخصائى الاجتماعي فى برامج وأساليب الرعاية للايتام بالمؤسسات الايوائية .

\begin{tabular}{|c|c|c|c|c|c|c|c|c|}
\hline \multirow{2}{*}{ الترتيب } & \multirow{2}{*}{ الدلالة } & \multirow{2}{*}{ 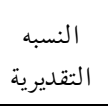 } & \multirow{2}{*}{ 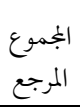 } & \multicolumn{3}{|c|}{ 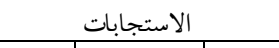 } & \multirow{2}{*}{ العبارات } & \multirow[b]{2}{*}{ p } \\
\hline & & & & ע & إلى حد ما & نعم & & \\
\hline 1 & منخفض & or, \& & $\varepsilon \varepsilon$ & 19 & r & V & أحرص على مساعدة اليتيم على النحو الاجتماعي السليم & 1 \\
\hline r & منخفض & $01, \cdot$ & $\varepsilon r$ & 19 & $r$ & 7 & أحاول تنمية قيمة العطاء لدي الأيتام & r \\
\hline$r$ & منخفض & $0 \cdot, \cdot$ & $\varepsilon r$ & 19 & $\varepsilon$ & 0 & بالبجتمع الخملى لزيادة زيـادة التقـارب بـــن الأيتـام وفئـات المـواطنين & $r$ \\
\hline 1 & منخفض & or,§ & $\varepsilon \varepsilon$ & 19 & r & $\checkmark$ & أسعي لتنمية قيم المسئولية الاجتماعية لدي الايتام . & $\varepsilon$ \\
\hline$\varepsilon$ & منخفض & $\{\Lambda \Lambda$ & \&) & 19 & 0 & $\varepsilon$ & أسعى لزياة احساس الايتام بشكلات الجتمع & 0 \\
\hline \multirow[t]{2}{*}{0} & منخفض & $\varepsilon V, 7$ & $\varepsilon \cdot$ & 19 & 7 & r & ألاول تخفيف مشاعر العزلـه والاشـتبعاد الاجتمـــي لــي & 7 \\
\hline & & & Y৭\& & & & & 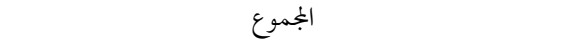 & \\
\hline \multicolumn{7}{|c|}{ النسبة التقديرية = ع,0.0 ٪ منخفض } & المتوسط المرجح العام = مَ"1, & \\
\hline
\end{tabular}

يوضح جدول (·1) استجابات المبحوثين من الأخصائين الاجتماعين " بجتمع الدراسـة " حول مؤشر الخدمة العامة كأحد أنشطة الممارسة العامة التى يستخدمها الأخصـائى الاجتمـاعي فى برامج وأساليب الرعايـة الاجتماعيـة للايتـام بالمؤسسـات الايوائيـة ، وفـى ضـوء حسـاب المتوسط المرجح والنسبة التقديرية ودلالات العبارت الدالة على هذا المؤشر وترتيبهـا وجـــ أن لن المتوسط المرجح العـام = (مبرام ) بينمـا كانـت النسـبة التقديريـة العامـة لمسـتوي اسـتخدامه للخدمة العامة (؟,_0 ٪ ) وهي قيمة منخفضة ، وهـذا يؤكـد أن مسـتوي اسـتخدامه للخدمـة العامة فى برامج وأساليب الرعاية الاجتماعية (منخفض ).

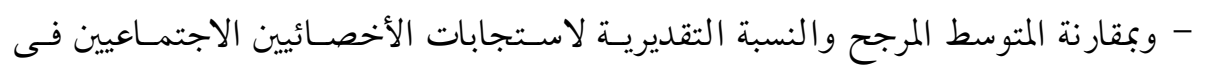
عبارات مؤشر الخدمة العامة وجد أنها تتوزيع توزيعاً احصائياً فى مسـتوي واحسـ (مـنخفض ) 
احرص على مساعدة اليتيم على النمو الاجتماعي السـليم ، يسـاويها اسـعي لتنميـة قيم

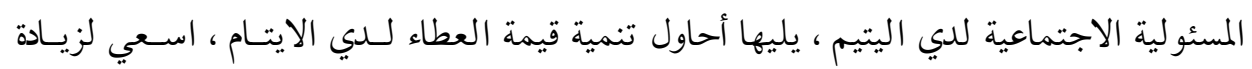

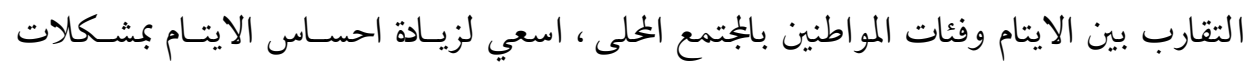

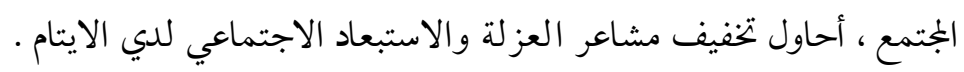

$$
\text { جدول رقم (II) }
$$

يوضح المتوسط المرجح والنسبه التقديرية لدرجات المبحوثين فيما يتعلق باستخدامهم لانشطة الممارسة العامة فى برامج الرعاية الاجتماعية للايتام بالمؤسسات الايوائية .

\begin{tabular}{|c|c|c|c|c|c|c|c|c|}
\hline \multirow[b]{2}{*}{ الترتيب } & \multirow{2}{*}{ 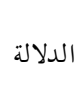 } & \multirow{2}{*}{ التقديرية النسبه } & \multirow{2}{*}{ المرجموع } & \multicolumn{3}{|c|}{ الاستجابات } & \multirow{2}{*}{ العبارات } & \multirow[b]{2}{*}{$\rho$} \\
\hline & & & & y & إلى حد ما & نعم & & \\
\hline r & متوسط & ז & 0.4 & $4 \pi$ & 79 & 9) & الرحلات & 1 \\
\hline 1 & مرتفع & Mo & 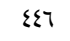 & r & ir & (ITI & حفلات السمر & r \\
\hline r & متوسط & $0 / 0$ & ५৭६ & 97 & M & o\& & المعسكرات & $r$ \\
\hline$\varepsilon$ & ضعيف & $0 \cdot, \xi$ & ros & $11 \varepsilon$ & rr & $\pi$ & الخدمة العامة & $\varepsilon$ \\
\hline & & & $1 \leqslant 9 V$ & & & & الجموع & \\
\hline \multicolumn{7}{|c|}{ النسبة التقديرية = +,77 متوسط } & المتوسط المرجح العام = r,o & \\
\hline
\end{tabular}

يوضح الجدول رقم (11) استجابات المبحوثين من الأخصائيين الاجتماعين " بجتمع البحث : بمستوي استخدامهم لأنشطة الممارسة العامه فى برامج وأساليب الرعاية الاجتماعية للايتام بالمؤسسات الايوائية ، وفى ضوء حساب المتوسط المرجح والنسبة التقديرية ودلالة

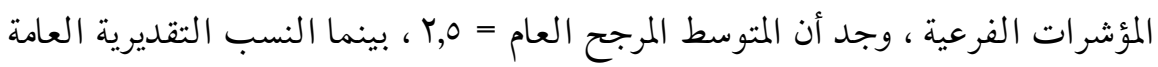

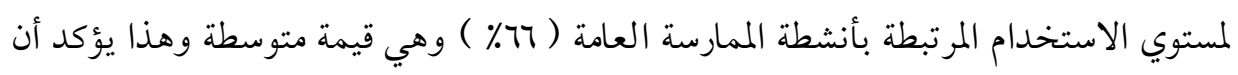
مستوي استخدام الأخصائين الاجتماعيين لأنشطة الممارسة العامة فى برامج وأساليب الرعاية الاجتماعية للايتام بالمؤسسات الايوائية (متوسط ) .

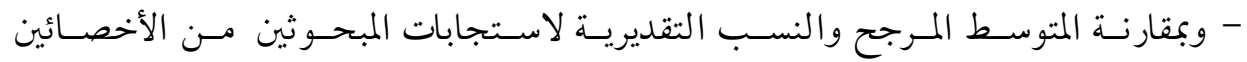

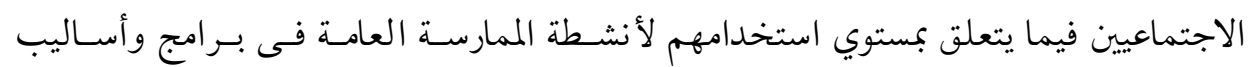

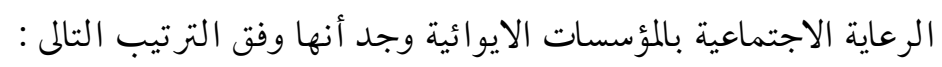


- حفلات السمر : احتلت المرتبة الأولى بمتوسط مرجح = Y,V ونسبة تقديرية M,O٪ وهي قيمة مر تفعة .

- الرحلات : احتلت المرتبة الثانثة بمتوسط مرجح = 1,9 ونسبة تقديرية ؟9,ه ٪ وهي قيمة متوسطة .

- المعسكرات : احتلت المرتبة الثالثة بمتوسط مرجح =1,V0 و ونسبة تقديرية 01,0\% وهي قيمة متوسطة .

- الخدمة العامة : احتلت المرتبة الرابعة بمتوسط مرجح = مऍ,1 ونسبة تقديرية ؟,0٪ وهي قيمة ضعيفة . : (ج) التساؤل الفرعي الثالث ما مهارات الممارسة العامة للخدمة الاجتماعية التى يستخدمها الأخصائى الاجتماعي فى برامج وأساليب الرعاية الاجتماعية للايتام بالمؤسسات الايوائية؟ ويمكن الاجابة على هذا التساؤل من خلال المؤشرات التالية :

$$
\text { المؤشر الأول : مهارة التخطيط للبرامج والأنشطة }
$$

يوضح المتوسط المرجح والنسبة التقديرية لدرجات المبحوثين فى عبارات مؤشر مهارة التخطيط للبرامج والانشطة كأحد مهارات الممارسة العامة التى يستخدمها الأخصائى

\begin{tabular}{|c|c|c|c|c|c|c|c|c|}
\hline \multirow{2}{*}{ 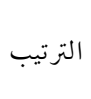 } & \multirow{2}{*}{ الدلالة } & \multirow{2}{*}{ 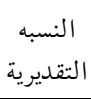 } & \multirow{2}{*}{ 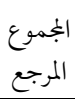 } & \multicolumn{3}{|c|}{ الاستجابات } & \multirow{2}{*}{ 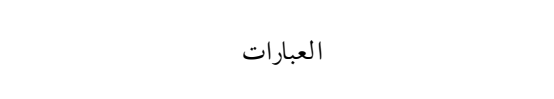 } & \multirow[b]{2}{*}{ p } \\
\hline & & & & لا & 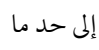 & نعم & & \\
\hline 1 & 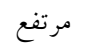 & $\wedge 7,9$ & r & r & $\circ$ & r. & أضع ميزانية وتكلفة كل برنامج بصورة دقيقة & 1 \\
\hline r & 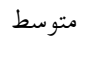 & 79. & ه & $\wedge$ & 1. & 1. & ) أقوم بترتيب برامج الرعاية بحسب أهميتها لليتيم (أولويات & r \\
\hline r & 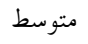 & $T V, \cdot$ & ov & a & 9 & 1. & أحرص على تحديد وقت معين لكل برنامج وفق أهدافه & $r$ \\
\hline$\varepsilon$ & منخفض & $0 \cdot, \cdot$ & $\varepsilon r$ & 19 & $\varepsilon$ & $\circ$ & السابقة على دعوة فريق العمل للمشاركة فى كل الخطـوات & $\varepsilon$ \\
\hline & & & $r$. & ra & ५ & \&o & 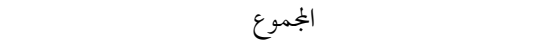 & \\
\hline \multicolumn{7}{|c|}{ النسبة التقديرية = ع $7, \varepsilon$ متوسط } & المتوسط المرجح العام = r & \\
\hline
\end{tabular}
الاجتماعي فى برامج وأساليب الرعاية للايتام بالمؤسسات الايوائية . 


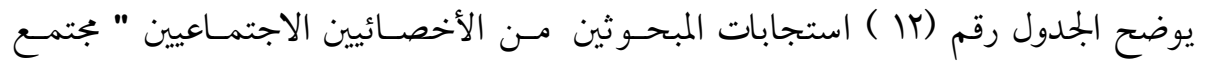

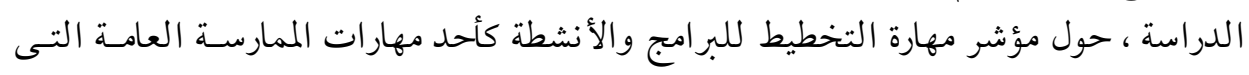

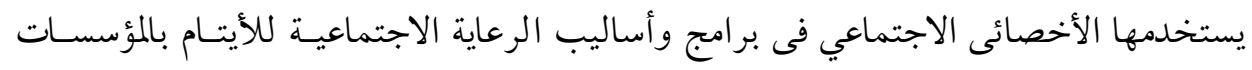

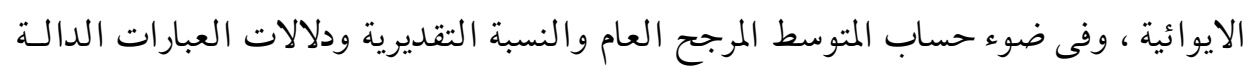

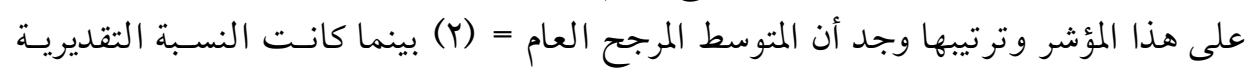

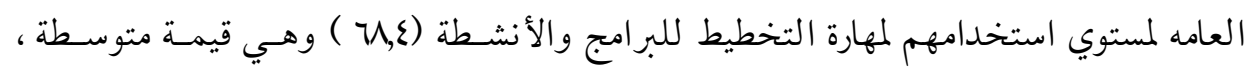

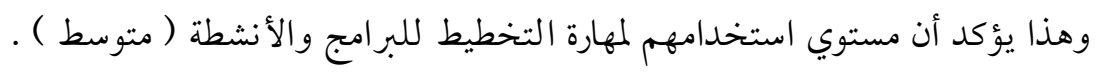

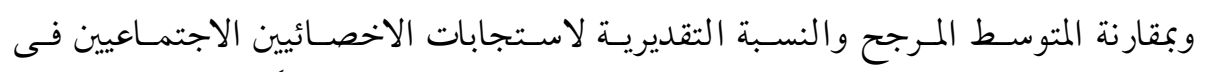

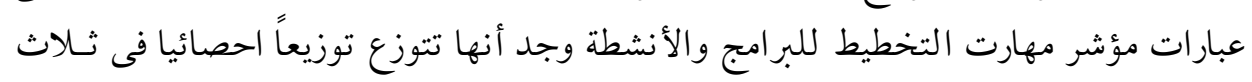
مستويات كالتالى : مؤشر مهارت

- عبارات حصلت على مستوي مرتفع وهي : أضع ميزانية وتكلفه كل برنامج بصوره دقيقة .

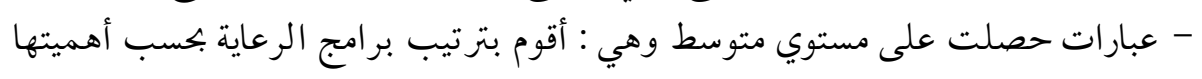

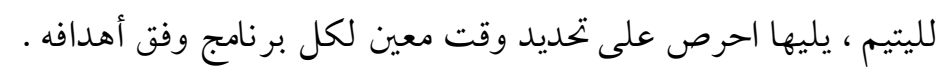

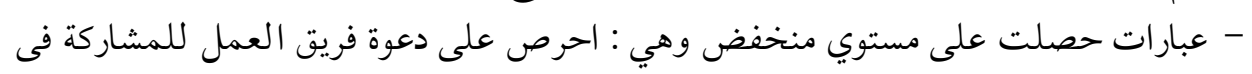
كل الخطوات السابقة r- المؤشر الثاني : مهارة ادارة الوقت المتابة

جدول رقم (II) )

يوضح المتوسط المرجح والنسبة التقديرية لدرجات المبحوثين فى عبارات مؤشر مهارة إدارة

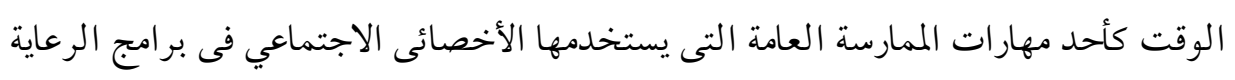
للايتام بالمؤسسات الايوائية .

\begin{tabular}{|c|c|c|c|c|c|c|c|c|}
\hline \multirow{2}{*}{ 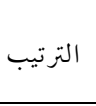 } & \multirow{2}{*}{ 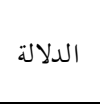 } & \multirow{2}{*}{ التقديرية } & \multirow{2}{*}{ المرجموع } & \multicolumn{3}{|c|}{ الاستجابات } & \multirow{2}{*}{ 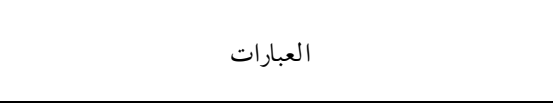 } & \multirow[b]{2}{*}{$\rho$} \\
\hline & & & & y & 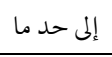 & نعبم & & \\
\hline 1 & 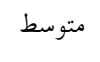 & $7 V, 9$ & ov & 9 & 9 & 1. & أحلد الأهداف المرادتحقيقها من البرنامج & 1 \\
\hline r & 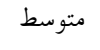 & 70,0 & $\infty 0$ & 11 & 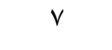 & 1. & أسعي لتحقيق أهداف البرنامج فى المدة التى سبق تحديدها & r \\
\hline \multirow[t]{2}{*}{ r } & منخفض & or, & 乏o & M & r & $v$ & أحرص على عدم وجود مضيعات للوقت & $r$ \\
\hline & & $10 \mathrm{~V}$ & ↔ & 19 & iv & & 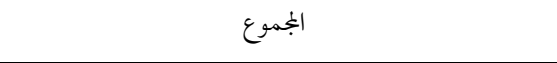 & \\
\hline \multicolumn{7}{|c|}{ النسبة التقديرية -؟r,T متوسط } & المتوسط المرجح العام = 1,9 & \\
\hline
\end{tabular}


يوضح الجحدول رقم (rا) استجابات المبحـوثين مسن الأخصـائيين الاجتمـاعيين " بجتمـع

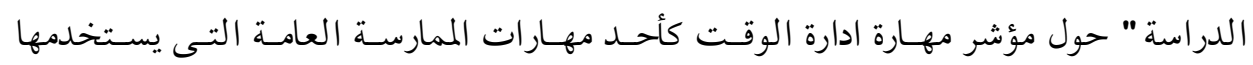

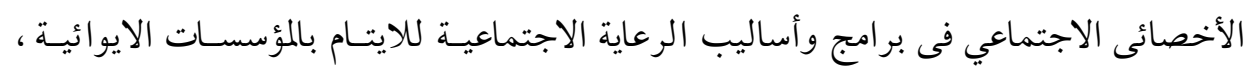
وفى ضوء حساب المتوسط المرجح العام والنسبه التقديرية ودلالات العبارات الدالة على هـذا تها

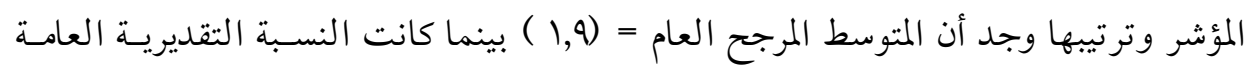

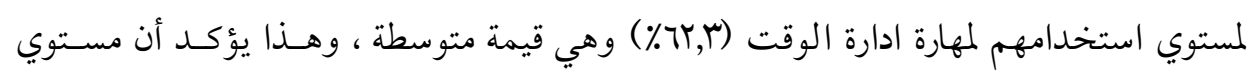
استخدامهم لمهارة ادارة الوقت ( متوسط ) . - وبمقارنة المتوسط المرجح والنسبه التقديرية لاستجابات الاحصائيين الاجتماعيين فى عبارات مؤشر مهارة ادارة الوقت وجد أنها تتوزعاً احصائياً فى مستويين كالتالى :

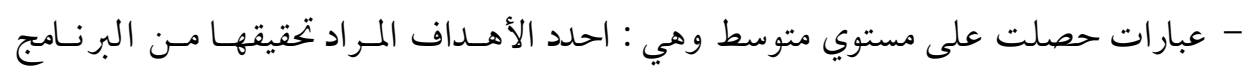
يليها اسعي لتحقيق اهداف البرنامج فى المدة التى سبق تحديدها . - عبارات حصلت على مستوي منخفض وهي : احرص على عدم وجود مضيعات للوقت .

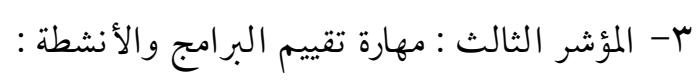

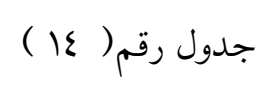

يوضح المتوسط المرجح والنسبة التقديرية لدرجات المبحوثين فى عبارات مؤشر مهارة تقييم

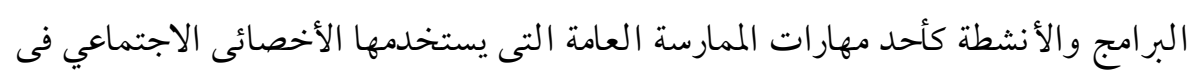
برامج وأساليب الرعاية للايتام بالمؤسسات الايوائية :

\begin{tabular}{|c|c|c|c|c|c|c|c|c|}
\hline \multirow[b]{2}{*}{ الترتيب } & \multirow{2}{*}{ 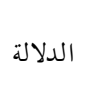 } & \multirow{2}{*}{ 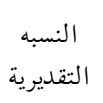 } & \multirow{2}{*}{ 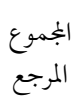 } & \multicolumn{3}{|c|}{ الاستجابات } & \multirow{2}{*}{ العبارات } & \multirow[b]{2}{*}{$\rho$} \\
\hline & & & & ل & 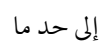 & نعم & & \\
\hline r & 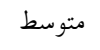 & vo, & rי & $\wedge$ & $\circ$ & 10 & أقوم بتقييم البرامج من خلال مدي ما تحققه من أهداف & 1 \\
\hline 1 & 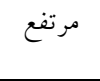 & $\mathrm{AV}$, & r & $r$ & $\circ$ & r. & السرامع لمعرفة مدي مناسبة الموارد والامكانات المتاحـة لنوعيـة & r \\
\hline r & منخفض & $0 \cdot, \cdot$ & $\varepsilon r$ & 19 & $\varepsilon$ & 0 & أحرص على مشاركة الايتام فى عملية التقييم للبرامج & $r$ \\
\hline$\varepsilon$ & منخفض & $0 \cdot, \cdot$ & \&r & 19 & $\varepsilon$ & $\circ$ & تح تحقيقه من على مشدافركة فريق العمل فى تصميم الـبرامج ومـا & $\varepsilon$ \\
\hline & & & TrV & $\varepsilon \varepsilon$ & r & $\varepsilon v$ & 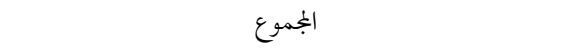 & \\
\hline \multicolumn{7}{|c|}{ النسبة التقديرية = •,rآ متوسط } & المتوسط المرجح العام = r,r, & \\
\hline
\end{tabular}


يوضح الجلدول رقم (ع)) اسـتجابات المبحــوثين مسن الأخصـائيين الاجتمـاعيين " مجتمـع

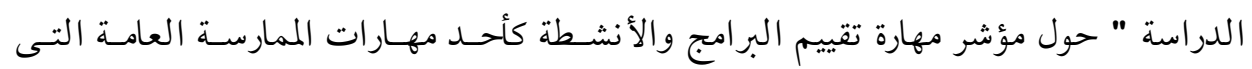

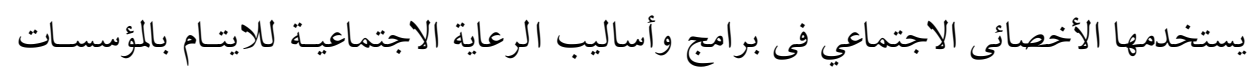
الايوائية ، وفى ضوء حساب المتوسط المرجح العام ، والنسبة التقديرية وددلات العبارات الدالة

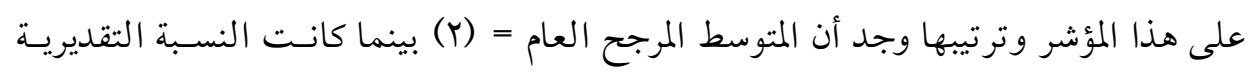
العامة لمستوي استخدامهم لمهارة تقييم البرامج والأنشطة (·,rا٪) وهي قيمة متوسطة ، وهـــا

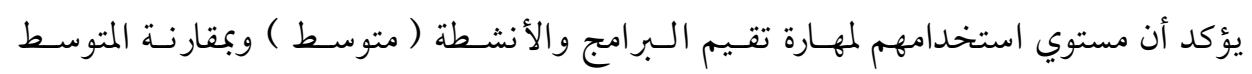
المرجح والنسبة التقديرية لاستجابات الأخصائيين الاجتماعيين فى عبارات مؤشر مهارة تقيسيم البرامج والأنشطة وجد انها تتتوزع توزيعا احصائيا على ثلاث مستويات كالتالى : - عبارات حصلت على مستوي مرتفع وهي : اسعي لمعرفة مدي مناسبة الموارد والامكانات المتاحة لنوعية البرامج بالمؤسسه . - عبارات حصلت على مستوي متوسط وهي : أقوم بتقييم البرامج من خلال مدي ما تحققه من أهداف . مباز - عبارات حصلت على مستوي منخفض وهي : احرص على مشاركة فريق العمل فى تقيسيم

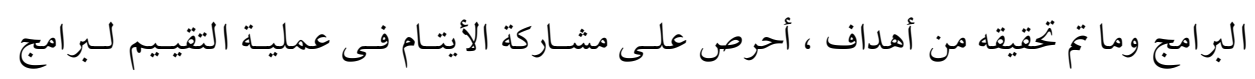
وأساليب الرعاية .

ع- المؤشر الرابع : مهارة المتابعة: 


$$
\text { جدول رقم (10 ) - (10) }
$$

يوضح المتوسط المرجح والنسبة التقديرية لدرجات المبحوثين فى عبارات مؤشر مهارة المتابعة

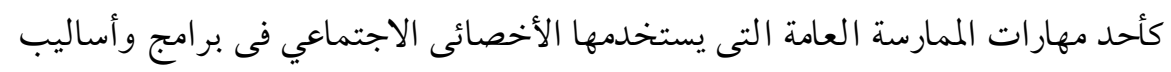
الرعاية للايتام بالمؤسسات الايوائية :

\begin{tabular}{|c|c|c|c|c|c|c|c|c|}
\hline \multirow{2}{*}{ 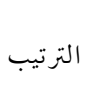 } & \multirow{2}{*}{ 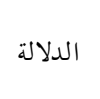 } & \multirow{2}{*}{ 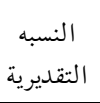 } & \multirow{2}{*}{ 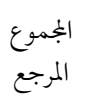 } & \multicolumn{3}{|c|}{ الاستجابات } & \multirow{2}{*}{ العبارات } & \multirow[b]{2}{*}{ p } \\
\hline & & & & لا & 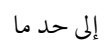 & نعم & & \\
\hline r & 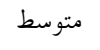 & $v \cdot, r$ & 89 & $v$ & 11 & 1. & أقوم بتابعة مدي ارتباط البرامج بإشباع احتياجات الايتام & 1 \\
\hline r & 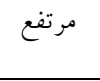 & $\mathrm{V} \wedge \mathrm{T}$ & 77 & $\varepsilon$ & 1. & $1 \varepsilon$ & ألايتام على متابعة مــدي ارتبــاط الــبرامج بحـل مشـكلات & $r$ \\
\hline 1 & 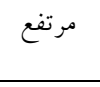 & vq, & TV & $\varepsilon$ & 9 & 10 & تحقيق أهدافها. & $r$ \\
\hline$\varepsilon$ & منخفض & or,r & $\varepsilon$ & M & $\varepsilon$ & 7 & 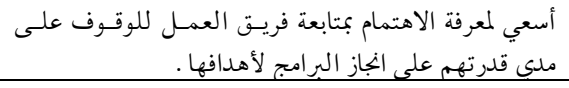 & $\varepsilon$ \\
\hline & & & rm & $\pi$ & $\mu \varepsilon$ & 乏o & 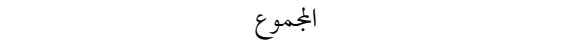 & \\
\hline \multicolumn{7}{|c|}{ النسبة التقديرية = V·, متوسط } & المتوسط المرجح العام = l, & \\
\hline
\end{tabular}

يوضح الجـدول رقـم (10) اسـتجابات المبحـوثين مسن الاخصـائيين الاجتمـاعيين "بجتمـع

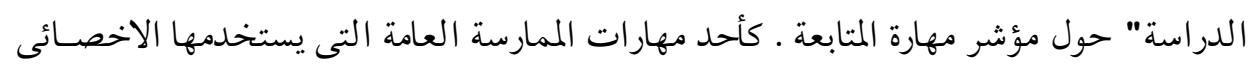

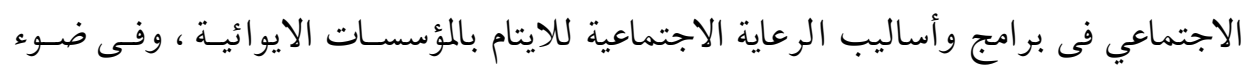

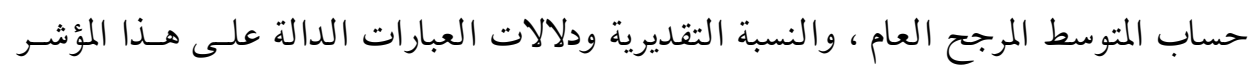

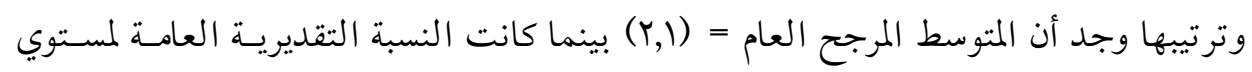

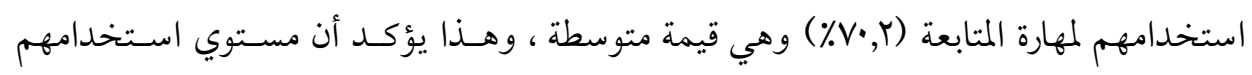

$$
\text { لمهارة المتابعة (متوسط ). }
$$

- وبمقارنة المتوسط المرجح والنسبة التقديرية لاستجابات الأخصائيين الاجتماعيين فى عبارات المتابعة وجد أنها تتوزع توزيعاً احصائياً على ثلاث مستويات كالتالى : - عبارات حصلت على مستوي مرتفع وهي : أحلد المشكلات التى تعوق البرامج عن تحقيـق أهدافها ، يليها احرص على متابعة مدي ارتباط البرامج بحل مشكلات الايتام .

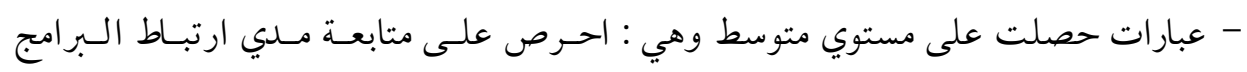

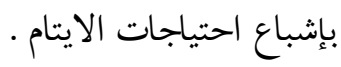


- عبار ات حصلت على مستوي منخفض وهي : اهتم بمتابعة فريق العمل للوقوف على مــي

$$
\text { قد قدرتهم على انجاز البرامج لأهدافها . }
$$

$$
\text { جدول رقم (17) (17) }
$$

يوضح المتوسط المرجح والنسبة التقديرية لدرجات المبحوثين فى عبارات مؤشر المهارات

\begin{tabular}{|c|c|c|c|c|c|c|c|c|}
\hline \multirow{2}{*}{ الت الترتب } & \multirow{2}{*}{ 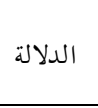 } & \multirow{2}{*}{ التقديبه } & \multirow{2}{*}{ 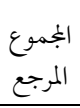 } & \multicolumn{3}{|c|}{ الاستجابات } & \multirow{2}{*}{ العبارات } & \multirow[b]{2}{*}{ p } \\
\hline & & & & y & إلى حد ما & نعم & & \\
\hline r & متوسط & $\pi, \cdot$ & or & $1 \varepsilon$ & $\varepsilon$ & 1. & 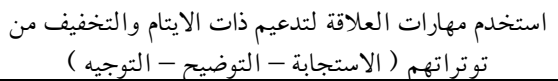 & 1 \\
\hline$\varepsilon$ & منخفض & or, \& & $\varepsilon \varepsilon$ & 19 & r & $v$ & العزلة الخدم مهارات أنشطة التدخل المهني لتخفيف الاجتماعي للايتام ( المبادرة - تقديم & r \\
\hline$r$ & 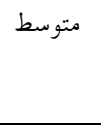 & $7 \cdot, \mathrm{V}$ & 01 & 10 & $r$ & 1. & مشاعرهم السلبية كالغضية مهارات مهنية لاتاحة الفرصة للايتام للتعبير عن ( المقابلة - الأفراغ & $r$ \\
\hline r & متوسط & $\pi, \cdot$ & or & 10 & r & 11 & 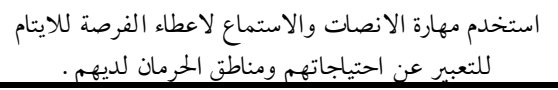 & $\varepsilon$ \\
\hline \multirow[t]{2}{*}{1} & مرتفع & r & v. & $\varepsilon$ & 7 & M & استخدم مهارة إعداد التقارير لتحقق التقييم المستمر & 0 \\
\hline & & & r7q & TV & IV & 07 & 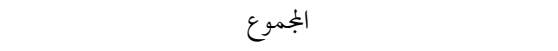 & \\
\hline \multicolumn{7}{|c|}{ النسبة التقديرية = 7, •7 متوسط } & المتوسط المرجح العام = 1,1 & \\
\hline
\end{tabular}
الأساسية للممارسة العامة التى يستخدمها الاخصائى الاجتماعي فى برامج وأساليب الرعاية لايتام بالمؤسسات الايوائية .

يوضح جدول رقـم (17) اسـتجابات المبحـوثين مـن الأخصـائيين الاجتمــاعيين " ججتمـع الدراسة" حول مؤشر المهارات الأساسية للممارسة العامة كأحد مهارات الممارسة العامة التى يستخدمها الأخصائى الاجتماعي فى برامج وأساليب الرعاية الاجتماعيـة للايتـام بالمؤسسـات الايوائية ، وفى ضوء حساب المتوسـط المـرجح العـام ، والنسـبة التقديريـة ودلالات العبـارات

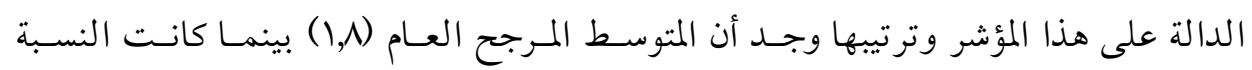
التقديرية العامة لمستوي استخدامهم لهذه المهارات الأساسـية للممارسـة العامـة 7,7، ٪ وهـي قيمة متوسطة ، وهذا يؤكد أن مستوي استخدامهم للمهارات العامة ( متوسط ) . 
-وبمقارنة المتوسط المرجح والنسبة التقديرية لاستجابات الأخصائيين الاجتماعيين فى عبـارت مؤشر المهارات الأساسية للممارسة العامة ـ وجد أنهـا تــوزع توزيعـا احصـائيا على ثـلاث مستويات كالتالى : - عبارات حصلت على مستوي مرتفع وهي : استخدم مهارة إعداد التقارير لأنها تحقق التقيم المستمر للمؤسسه وبرابجها. - عبارات حصلت على مستوي متوسط وهي : استخدام مهارات الاتصال والاستماع لاعطـاء الفرصة لليتيم للتعبير عن احتياجاته ، يليها اسـتخدام مهـارات العلافـة لتـدعيم ذات اليتـيم

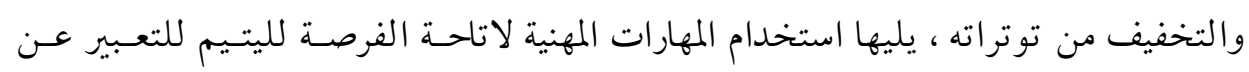

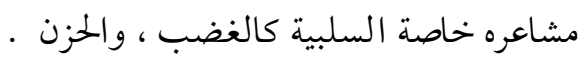
- عبارات حصلت على مستوي منخفض وهـي : اسـتخدام مهـارات انشطة التـدخل المهني لتخفيف مشاعر العزلة والاستبعاد الاجتماعي . 
1- المؤشر السادس : مهارة الاتصال :

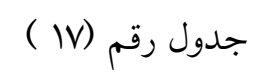

يوضح المتوسط المرجح والنسبة التقديرية لدرجات المبحوثين فى عبارات مؤشر مهارة الاتصال

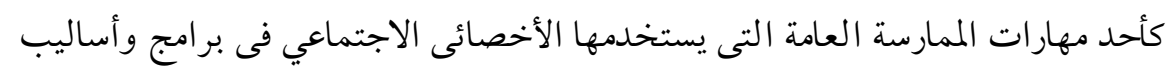
الرعاية للايتام بالمؤسسات الايوائية. .

\begin{tabular}{|c|c|c|c|c|c|c|c|c|}
\hline \multirow{2}{*}{ الترتيب } & \multirow{2}{*}{ 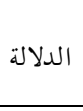 } & \multirow{2}{*}{ 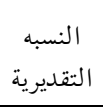 } & \multirow{2}{*}{ 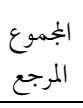 } & \multicolumn{3}{|c|}{ الاستجابات } & \multirow{2}{*}{ العبارات } & \multirow[b]{2}{*}{$p$} \\
\hline & & & & $y$ & إلى حد ما & نعم & & \\
\hline 1 & مرتفع & $\mathrm{V} \wedge \mathrm{T}$ & 77 & $\checkmark$ & $\varepsilon$ & IV & 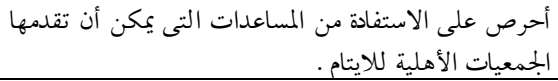 & 1 \\
\hline r & متوسط & $V \cdot, r$ & 09 & $\wedge$ & 9 & 11 & كل مل مل على تمقيق المسد ، الكنائسم الديني لنزلاء المؤسسه بــا تسـاهمه & r \\
\hline r & متوسط & vo, & זד & $\wedge$ & 0 & 10 & ألحاول زيادة مشاركة أعضاء الججتمع الخلى فى دعم المؤسسات & r \\
\hline & & & $M$ & r & M & $\varepsilon$ & الجموع & \\
\hline \multicolumn{7}{|c|}{ النسبة التقديرية = V乏,T متوسط } & المتوسط المرجح العام = r,Y & \\
\hline
\end{tabular}

يوضح جـدول رقـم (IV) اسـتجابات المبحـوثين مـن الأخصـائيين الاجتمـاعيين "بجتمـع

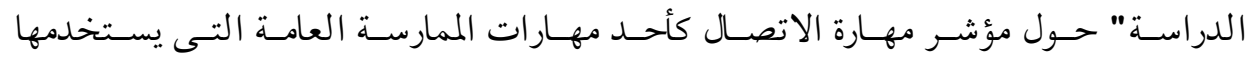
الأخصائيين الاجتماعيين فى برامج وأساليب الرعاية الاجتماعية للايتام بالمؤسسات الايوائيـة ، وفى ضوء حساب المتوط المرجح العام ، والنسبة التقديرية ودلالات العبارت الدالـة على هـــا

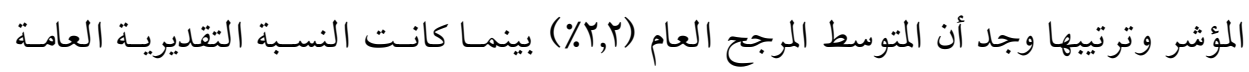

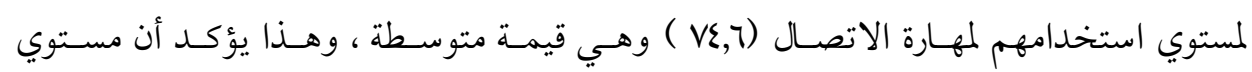
استخدامهم لمهارة الاتصال ( متوسط ) .

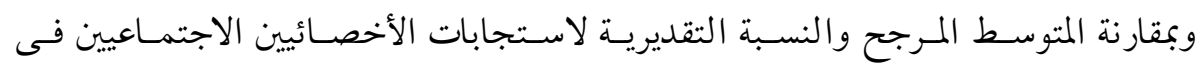
عبارات مؤشر مهارة الاتصال وجد أنها تتوزيع توزيعاً احصائيا على مستويين كالآتي :

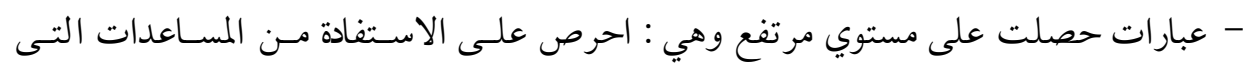
يكن أن تقدمها الجمعيات الأهلية للايتام . 
- عبارات حصلت على مستوي متوسط وهي : احاول زيادة مشاركة اعضاء الجتمع الخلى فى دعم المؤسسات الايو ائية ماديا ومعنويا ،يليها احرص على تحقيق الدعم الديني لنزلاء المؤسسة بما تساهمه كل من المساجد والكنائس .

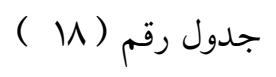

يوضح المتوسط المرجح والنسبة التقديرية لدرجات المبحوثين فيما يتعلق باستخدامهم لمهارات الممارسة العامه فى برامج وأساليب الرعاية للايتام بالمؤسسات الايوائية :

\begin{tabular}{|c|c|c|c|c|c|c|c|c|}
\hline \multirow{2}{*}{ الترتيب } & \multirow{2}{*}{ 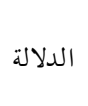 } & \multirow{2}{*}{ التقديرية } & \multirow{2}{*}{ المرجع } & \multicolumn{3}{|c|}{ الاستجابات } & \multirow{2}{*}{ مهارات الممارسة العامة التى يستخدمها في برامج وأساليب } & \multirow[b]{2}{*}{ p } \\
\hline & & & & لا & 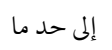 & نتم & & \\
\hline r & متوسط & $\eta \varepsilon$ & rr. & rq & ५ & so & مهارة التخطيط للبرامج والأنشطة & 1 \\
\hline$\varepsilon$ & 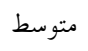 & $\pi, r$ & lov & r & 19 & iv & مهاراة ادارة الوقت & r \\
\hline 1 & 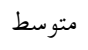 & $\pi, \cdot$ & TrV & $\varepsilon \varepsilon$ & r & $\varepsilon V$ & مهارة تقييم البرامج والأنشطة & $r$ \\
\hline r & 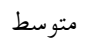 & $v \cdot, r$ & די & $\pi$ & $r \varepsilon$ & so & مهارة المتابعة & $\varepsilon$ \\
\hline$\circ$ & 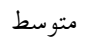 & $7 \cdot 7$ & r79 & TV & iv & 07 & المهارات الأساسية & ० \\
\hline 1 & 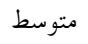 & $v \varepsilon, 7$ & M & $r$ & M & $\varepsilon$ & مهارة الاتصال & 7 \\
\hline & & & $\mid r \cdot v$ & r〔纟 & in & זוד & الجموع ال الجمو & \\
\hline \multicolumn{7}{|c|}{ النسبة التقديرية = TV,V متوسط } & المتوسط المرجح العام = r,r & \\
\hline
\end{tabular}

يوضـح الجــدول رقـم (W) اسـتجابات الأخصـائيين الاجتمـاعيين فيمـا يتعلـق بمسـتوى استخدامهم لمهارات الممارسة العامة فى برامج وأساليب الرعاية للأيتام بالمؤسسـات الايوائيسة،

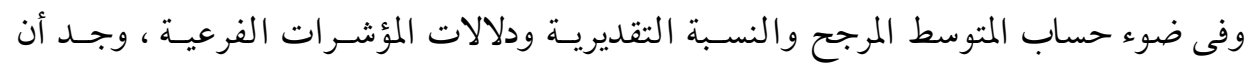
المتوسط المرجح العام = (Y,Y) بينما النسبة التقديريـة العامـة لمسـتوي اسـتخدامهم لمهـارات الممارسة العامة (V,V ٪ \% ) وهي قيمة متوسطة . وهذا يؤكـد أن مسـتوي اسـتخدامهم لمهارات

$$
\text { الممارسة العامة ( متوسط ) . }
$$

وبمقارنـة المتوسـط المـرجح والنسـبه التقديريـة لاسـتجابات المبحـوثين مـن الاخصـائيين

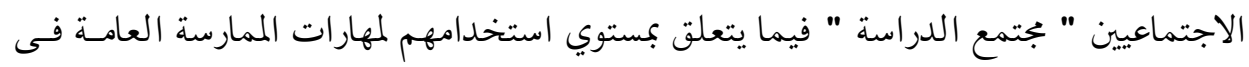
برامج وأساليب الرعاية الاجتماعية للايتام بالمؤسسات الايوائية وجد أنها وفق الترتيب التمبن التالى :

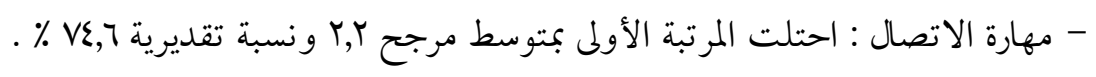


وهي قيمة (متوسطة ).

- مهارة المتابعة : احتلت المرتبة الثانية بمتوسط مرجح (1, ) و ونسبة تقديرية r, •V ٪ وهي قيمة (متوسطة) .

- مهارة التخطيط للبرامج والانشطة : احتلت المرتبة الثالثة بمتوسط مرجح (Y) ونسبة تقديرية

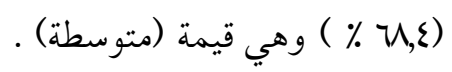

- مهارة إدارة الوقت : احتلت المرتبة الرابعة بمتوسط مرجح(1,9) ونسبة تقديرية؟ا٪ . وهي قيمة ( متوسطة ) . - مهارة تقيم البرامج والأنشطة : احتلت المرتبة السادسة بمتوسط مرجح ^,ا ونسبة تقديرية 7,7 ٪ وهي قيمة ( متوسطة ) . 


$$
\text { ( د) التساؤل الفرعي الرابع: }
$$

ما الأساليب الفنية للمارسة العامة التى يستخدمها الأخصائى الاجتماعي فى برامج وأساليب

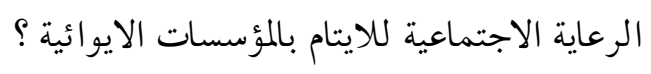

$$
\text { جدول رقم (19) }
$$

يوضح المتوسط المرجح والنسبه التقديرية لدرجات المبحوثين فيما يتعلق بالأساليب الفنية

\begin{tabular}{|c|c|c|c|c|c|c|c|c|}
\hline \multirow{2}{*}{ الترتيب } & \multirow{2}{*}{ 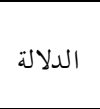 } & \multirow{2}{*}{ 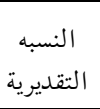 } & \multirow{2}{*}{ 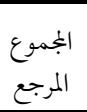 } & \multicolumn{3}{|c|}{ الاستجابات } & \multirow{2}{*}{ 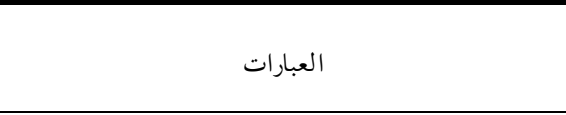 } & \multirow[b]{2}{*}{ م } \\
\hline & & & & ע & 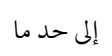 & نعم & & \\
\hline$\varepsilon$ & منخفض & $\{0, r$ & 队 & rr & r & $\varepsilon$ & التجاه سيكولوجية الذات يمكنني من تعديل التجاهات ومفهـوم & 1 \\
\hline$\varepsilon$ & منخفض & $\varepsilon 0, r$ & M & rI & $\varepsilon$ & $r$ & 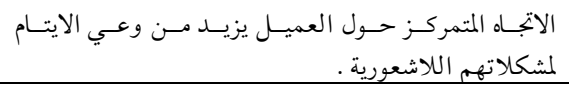 & r \\
\hline 0 & منخفض & $\xi \cdot, \varepsilon$ & $r \varepsilon$ & $r \varepsilon$ & r & $r$ & مفهوم التوجيه والارشاد النفسى يساعد فى تحديد مشكلات & $r$ \\
\hline 1 & منخفض & $0 \cdot, \cdot$ & $\varepsilon r$ & 19 & $\varepsilon$ & $\circ$ & بناءه وهادفة اتيجات تعليم القيم استخدمها لاكسـاب الايتـام قيم & $\varepsilon$ \\
\hline r & منخفض & $\{7, \xi$ & rq & r) & r & $\varepsilon$ & قد العلاج السلوكي يساعد فى تعديل السلوكيات الخاطئة التى & 0 \\
\hline r & منخفض & $\varepsilon \wedge \Lambda$ & \&) & $r$. & $r$ & $\circ$ & الذعلاج المعرفى استخدمه لتعديل السلوك الظاهرى السـلبى & 7 \\
\hline \multirow[t]{2}{*}{0} & منخفض & $\varepsilon \cdot, \varepsilon$ & $r \varepsilon$ & $r \varepsilon$ & r & r & 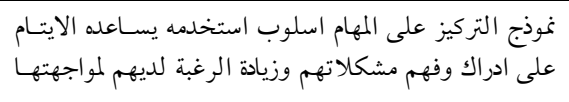 & $\mathrm{v}$ \\
\hline & & & Tוד & 101 & r. & ro & الجموع & \\
\hline \multicolumn{7}{|c|}{ النسبه التقديرية = r ؟ § منخفض } & المتوسط المرجح العام = ب, 1, & \\
\hline
\end{tabular}
للممارسة العامة التى يستخدمها الأخصائى الاجتماعي فى برامج وأساليب الرعاية للايتام بالمؤسسات الايوائية.

يوضح الجدول رقم (19) اسـتجابات المبحـوثين مـن الأخصـائيين الاجتمـاعيين " ججتمـع

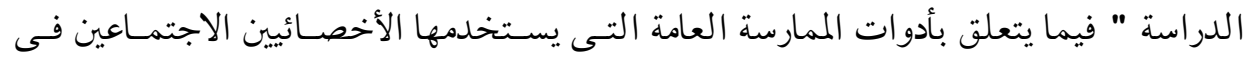
برامج وأساليب الرعاية الاجتماعية للايتام بالمؤسسات الايوائية ،وفى ضـوء حسـاب المتوسط المرجح والنسبة التقديرية ودلالات المؤشرات الفرعية ، وجد أن المتوسط المـرجح العـام (rار )

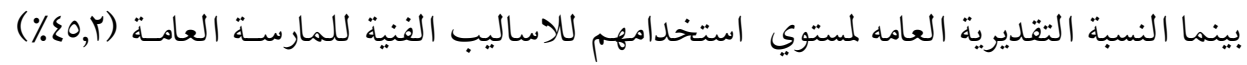


وهي قيمة منخفضة وهذا يؤكد أن مستوي اسـتخدامهم للأسـاليب الفنيـة لملمارســـ العامـة (منخفضة ) .

وبمقارنة المتوسط المرجح والنسبة التقديرية لاستجابات المبحوثين وجد أنها وفق الترتيـبـ

- استراتيجيات تعليم القـيم كأحــــ الأسـاليب الفنيـة للممارسـة العامـة والتى يسـتخدمها

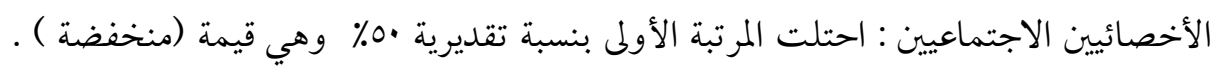

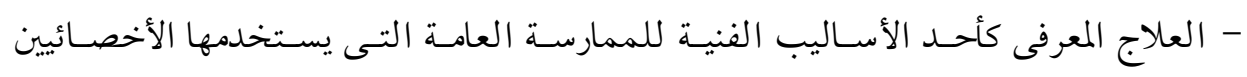

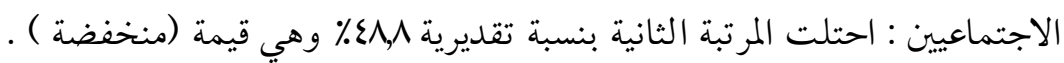
- العلاج السلوكي كأحد الأساليب الفنيـة للممارسـة العامـة التسى يستـخدمها الأخصـائيين

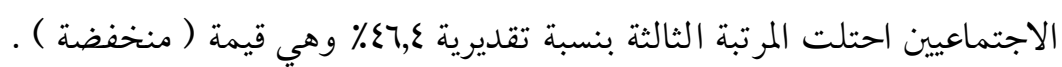

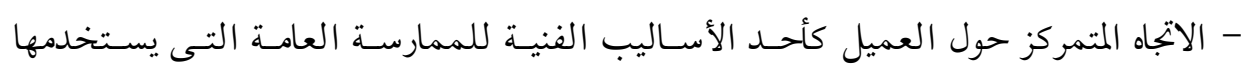

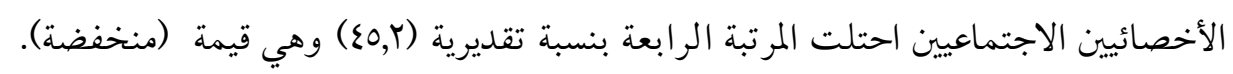

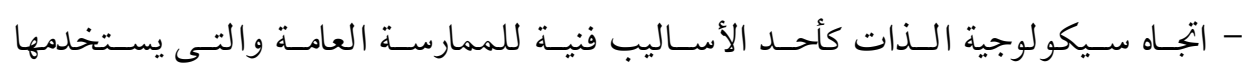

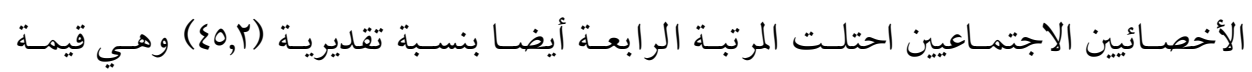

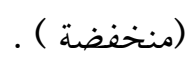

- مفهوم التوجيه والإرشاد النفسى كأحد الأساليب الفنية للممارسة العامـة التى يستخدمها

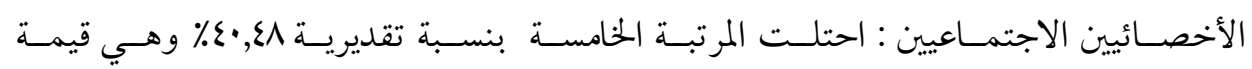
(منخفضة)

- نــوذج التركيـز علـى المهـام كأحســ الأسـاليب الفنيـة للممارسـة العامـة التى يسـتخدمها

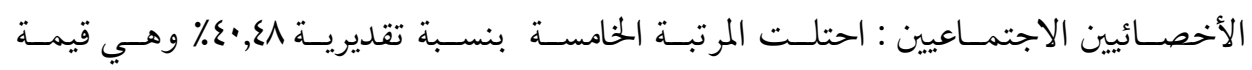
(منخفضة) 
ثامنـاً : الاجابـة علـى التســاؤل الرئيسـى الثـاني بالدراسـة وهــو : مــا الرؤيسة الممتقبلية لاسهامات الممارسـة العامـة للخدمـة الاجتماعيـة لنفعيـل بـرامج وأساليب الرعاية الاجتماعية للايتام بالمؤسسات الايوائية؟ فى ضوء العرض السابق للقضية موضوع الدراسة ، وفى ضـوء مـا توصـلت إليسه الدراسة من نتائج يمكن تحديد رؤية مسـتقبلية لاسـهامات الممارسـة العامـة للخدمـة الاجتماعيـة فـى تفعيـل بــرامج واسـاليب الرعايــة الاجتماعيـة للايتـام بالمؤسســات الايوائيةبالتركيز على الأدوات والأنشطة والمهارات والأساليب الفنيـة التـى حصـلت على نسبة إما منخفضة أو متوسطة كالأتي : أولاً : أهمية وضرورة استخدام الأخصائى الاجتماعي لأدوات الممارسة العامة للخدمة الاجتماعية لتفعيل برامج الرعاية الاجتماعية للايتام بالمؤسسات الايوائية ومنها : 1- المناقشة الجماعية حيث أنها تسهم فيما يلى :

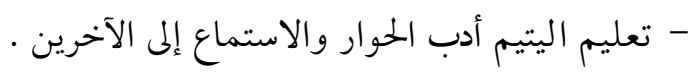
- مساعدة اليتيم للتعبير عن آرائه بحرية وإيجابية .

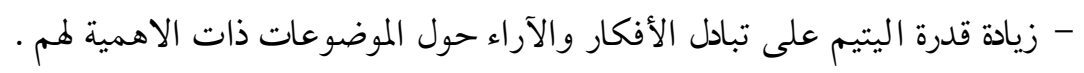
- تزيد من ثقة اليتيم فى نفسه وفى قدرته على عرض مشكلاته .

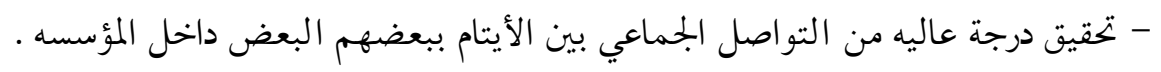

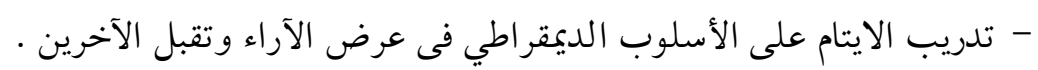

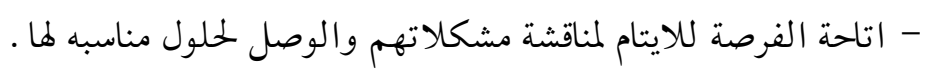
r- النمذجة حيث أنها تسهم فيما يلى : - عرض أفلام هادفة تتعرض لبعض مشكلات الأطفال بصفة عامة .

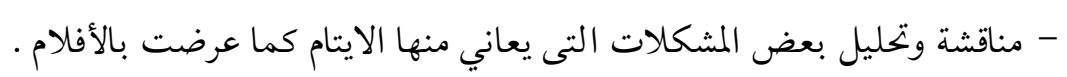
- توعية الأيتام بأساليب وطرف مواجهة مشكلاتهم . - مساعدتهم على كيفية تحديد اسباب ما يعانونه من مشكلات من خلال ما شاهدوه .

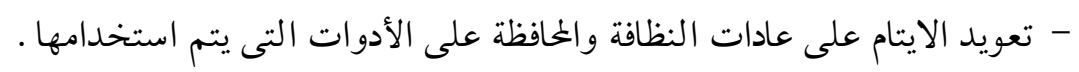




$$
\begin{aligned}
& \text { r- الخحاضرات حيق أنها تسهم فيما يلى : } \\
& \text { - تدريب الأيتام على الاسعافات الأولية . } \\
& \text { - تنمية الوعي الصحي للايتام . }
\end{aligned}
$$

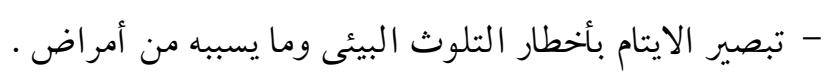

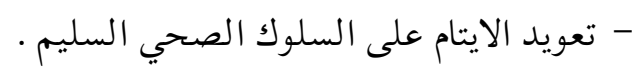

$$
\begin{aligned}
& \text { - تبصير الايتام بطرق الوقاية من الأمراض . } \\
& \text { - تبصير الايتام بأهمية مشاركتهم فى برامج المؤسسة . }
\end{aligned}
$$

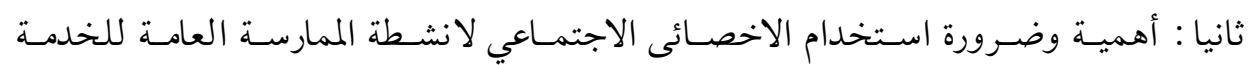
الاجتماعية لتفعيل برامج الرعاية الاجتماعية للايتام بالمؤسسات الايوائية ومنها :

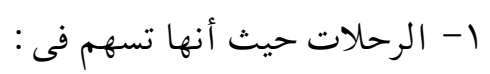

- تكوين علاقات اجتماعية ايجابية بين الايتام داخل المؤسسه .

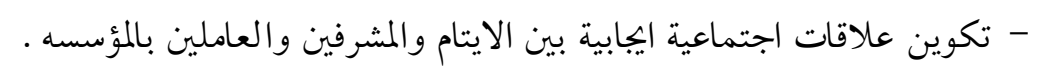
- مساعدة الايتام على التعرف بمجتمعهم الخارجي .

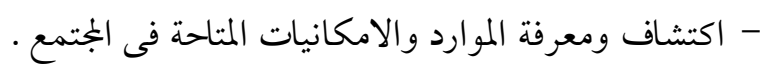
- تكوين معارف وصداقات جديدة للايتام خارج المؤسسه . - اكساب الايتام القدرة على تبادل الأدوار ( القيادة والتبعية ) . - تحقيق أهداف التنشئة الاجتماعية وبناء شخصية اليتيم . - زيادة فرص الاختلاط بالآخرين يكسب اليتيم انماطاً من السلوك تحقق رغباته .

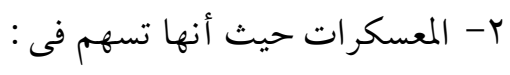

$$
\begin{aligned}
& \text { - تدعيم قيم الديمقر اطية لدي الايتام - } \\
& \text { - اشباع هوايات الايتام وممارستها . }
\end{aligned}
$$

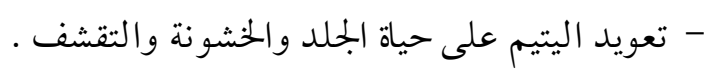

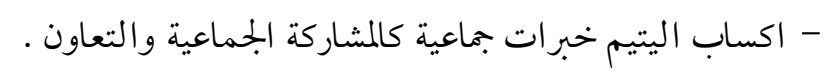
- رفع درجة الانتماء لدي الايتام للمؤسسه الايوائية المنتمين لما . 
ب- الخدمة العامة حيث أنها تسهم فى :

- مساعدة اليتيم على النمو الاجتماعي السليم . - تنمية قيمة العطاء لدي الايتام .

- زيادة التقارب بين الايتام وفئات المواطنين بالجزتمع الخحلى ل - تنمية قيم المسئولية الاجتماعية لدي الايتام .

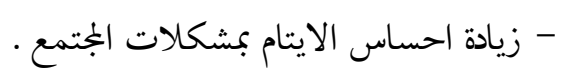
تخفيف مشاعر العزلة والاستبعاد الاجتماعي لدي الايتام . ثالثاً : أهمية وضرورة استخدام الأخصائى الاجتماعي لمهارات الممارسة العامة للخدمة الحئي الاجتماعية لتفعيل برامج الرعاية الاجتماعية للايتام فى المؤسسات الايوائية ومنها : 1- مهاراة التخطيط للبرامج والأنشطة حيث أنها تسهم فى : - وضع ميزانية وتكلفة كل برنامج بصورة دقيقة .

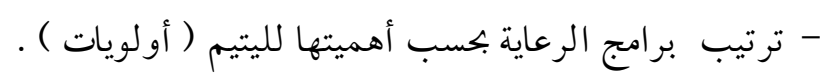
- تحديد وقت معين لكل برنامج وفق أهدافه . - دعوة فريق العمل للمشاركة فى كل الخطوات السابقة . Y- مهاراة إدارة الوقت حيث أنها تسهم فى :

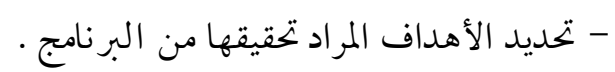

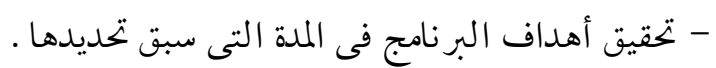
- عدم وجود مضيعات للوقت .

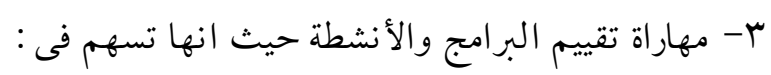

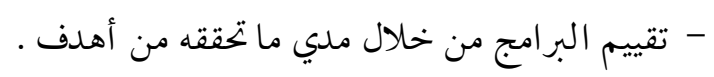
- معرفة مدي مناسبة الموارد والامكانات المتاحة لنوعية البرامج والمؤسسه .

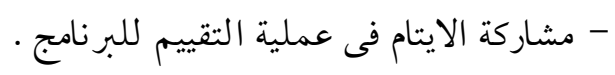
- مشاركة فريق العمل فى تصميم البرامج وما تم تحقيقه من أهداف . ع-مهارة المتابعة حيق أنها تسهم فى : - متابعة مدي ارتباط البرامج بإشباع احتياجات الايتام . 
- متابعة مدي ارتباط البرامج بحل مشكلات الايتام .

- تحديد المشكلات التى قد تعوق البرامج عن تحقيق أهدافها .

- الاهتمام بمتابعة فريق العمل للوقوف على مدي قدرتهم على انجاز البرامج لأهدافها .

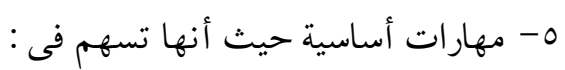

- تدعيم ذات الحدث وتخفيف توتراته ( مهارات العلاقة ) .

- تخفيف مشاعر العزلة والاستبعاد الاجتماعي للايتام ( مهارات أنشطة التدخل المهني ) .

- اتاحة الفرصة للايتام للتعبير عن مشاعرهم السلبية (مهارات مهنية ) .

- اعطاء الفرصة للايتام للتعبير عن احتياجاتهم (مهارات الانصات والاستماع ) .

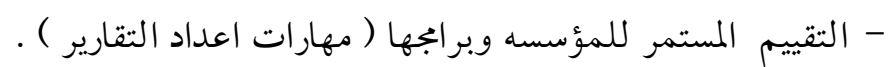
7- مهارة الاتصال حيث أنها تسهم فى :

- الاستفادة من المساعدات التى يمكن أن تقدمها الجمعيات الأهلية للايتام .

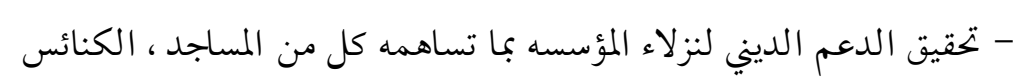

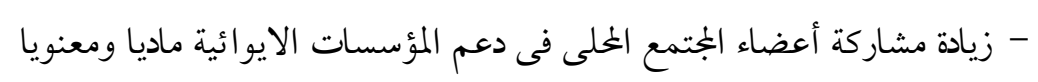

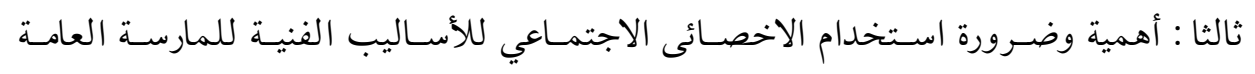

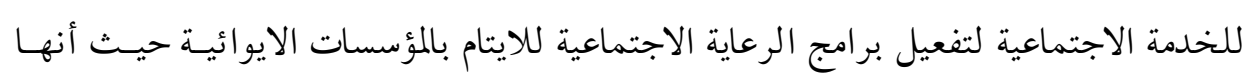
تسهم فيما يلى : - اتجاه سيكولوجية الذات يمكن من تعديل فيمات اتجاهات ومفهوم الذات لدي الايتام . - الاتجاه المتمركز حول العميل يزيد من وعي الاينام لمشكلاتهم اللاشعورية . - مفهوم التوجيه والارشاد النفسى يساعد فى تحديد مشكلات الايتام وطرف مو اجهتها . - استراتيجيات تعليم القيم استخدامها يكسب الايتام قيم بناءه وهادفة - العلاج السلوكي يساعد فى تعديل السلوكيات الخاطئة التى قد يتبناها بعض الايتام - العلاج المعرفى يستخدم لتعديل السلوك الظاهرى السلبى الذى قد يسـلكه بعـض الايتـام بالمؤسسه .

- نموذج التركيز على المهام اسلوب يساعد الايتام على ادراك وفهم مشكلاتهم وزيـادة الرغبـة لديهم لمواجهتها . 


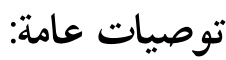

1- زيادة أعداد الأخصائين الاجتماعيين العاملين بمؤسسات رعاية الايتام . ץ- ضرورة تفعيل نظام " تدريب الأخصائيين الاجتماعين لزيادة قدرتهم على الممارسة العامه بالكفاءه التى تحقق الفاعلية لمؤسسات رعاية الايتام .

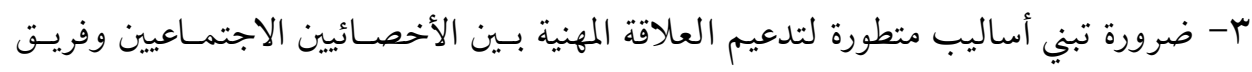

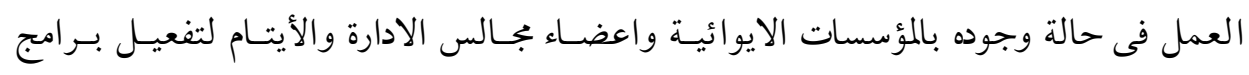
الرعاية الاجتماعية بالمؤسسات الايوائية .

ع- ضرورة تحقيق جودة المعارف والمهارات الأدوات وزيادة قدرة الأخصائسـيه الاجتماعيـة على تلى

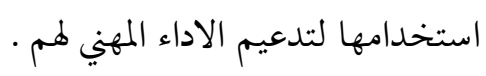
ه- ضرورة تنمية قدرة الأخصـائية الاجتماعيـة على تحليـل المواقـف الجماعيـة كـذلك تنميـة قدرتهم على اتخاذ القرارات المناسبة لتلك المواقف . 1- زيادة فرص التنسيق بــين مؤسســات رعايـة الايتـام والجمعيـات الأخــى بـالجتمع لتـدعيم

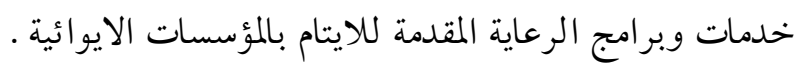

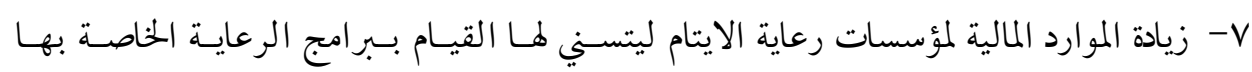

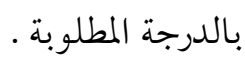
^- ضرورة استثمار وسائل الاعلام فى حث الجُتمع بكل فئاته على التواصل مـع مؤسسـات رعاية الايتام لمساعدتها لكي تحقق أهدافها بفاعلية عالية . ه- ضرورة تطوير قدرة الاخصائية الاجتماعية على استثمار المـوارد المتاحسة بـالجتمع للاسـتفادة منها فى تدعيم برامج الرعاية بالمؤسسات الايوائيه .

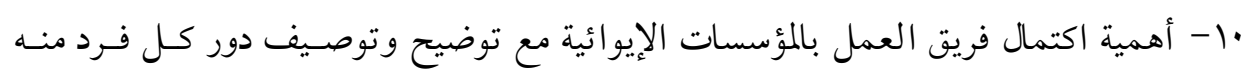

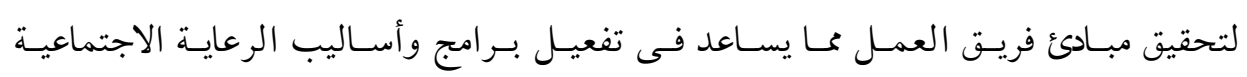
بالمؤسسات الايوائية للايتام . 


\section{المراجع}

1- عبــد الله ناصـر الســححان : أطفـال بـلا أســر ، الطبعـة الأولى ، مكتبـة العبيكـان ،

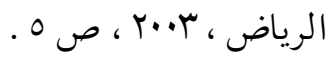

ץ- بجلس الوزراء ، مركز المعلومات ودعـم اتخـاذ القـرار ، وصـف مصـر بالمعلومـات ،

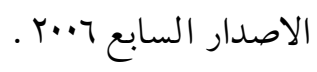

r- الجهاز المركزي للتعبئة العامة والاحصاء ، القاهرة ، ج+.ب . ع- عبد المنعم محمد حسين : الأسرة ومنهجها التربوي لتنشئة الأبنـاء فى عـالم مـتغير ،

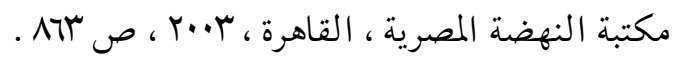
0- عادل كمال خضر - محمد إبراهيم الدسوقى : المؤسسات الايوائية بـين الاسـتيعاب، والاستدماج ، بحث منشور ، بجلة علـم الـنفس ، الميئـة العامـة للكتــاب ، القـاهرة ،

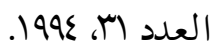

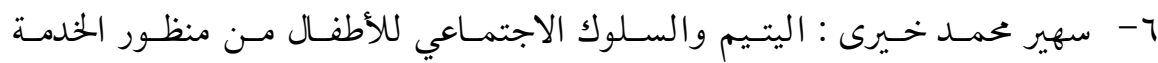
الاجتماعية ، بحث منشور المؤتمر العلمي الثاني أطفال فى خطر ، معهـد الدراسـات العليا للطفولة ، جامعة عين شمس ، 1998 ، ص بعr. - ماهر عبد الرازق سـكران : الحرمـان الأسـرى وعلاقتـه بالعزلـة الاجتماعيـة لـدي الأطفال ، بحث منشور ، المؤتمر العلمي التاسع ، كلية الخدمــة الاجتماعيـة ، جامعـة ، $\cdot r \cdot \cdot T$ ^- عبد الخي حممود صالح : الخدمة الاجتماعية وبحالات الممارسة المهنيـة ، الاسـكندرية ، دار الفكر الجامعي 1997 ، ص rV . r. 9- وزارة التأمينات والشئون الاجتماعية : المؤشرات الاحصـائية ، الادارة العامـة لمركـز المعلومات والتوثيت ودعم اتخاد القرار ، 199V ، ص MM . . • - الجهاز المركزي للتعبئة والاحصاء : احصاءات منشأت الرعايـة الاجتماعيـة ، 1991 ، ص 1ا- وزارة التأمينـات والشــون الاجتماعيـة : بيـان تفصـيلى عـن مؤسســات الاطفـال 
الخحرومين مـن الرعايـة الأســية ، الإدارة العامـة للأســـة والطفولـة ، إدارة الرعايـة

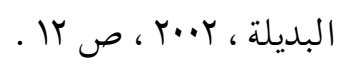

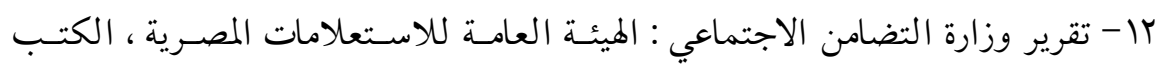

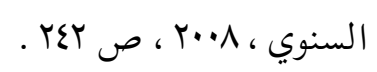

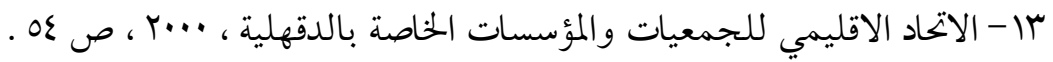

عا- ناديه زغلول سعيد ، مشكلات العملية التخطيطية لجمعيات رعاية الطفولة بمحافظة

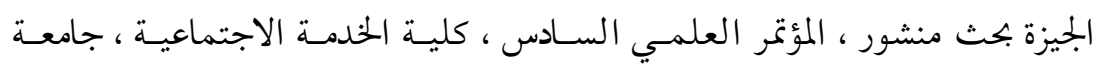

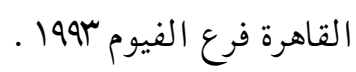

$$
\begin{aligned}
& \text { 10-عبد الخي محمود صالح : مرجع سبق ذكره ، ص } 19 \text { (م.0.0 ) ). }
\end{aligned}
$$

16-Pringle M.K:- Emotional Adjustment Among children in car , In Pringle deprivation And Education " , London Macmillan press, second.

IV - جمال شفيق أممد : سمـات شخصـية المـودعين بـبعض المؤسسـات الايوائيـة ، رسـالة

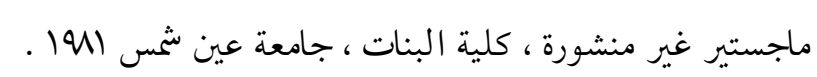

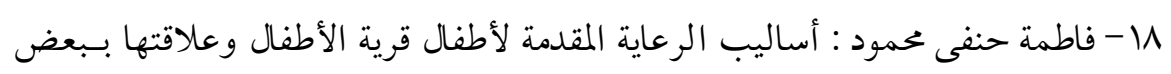

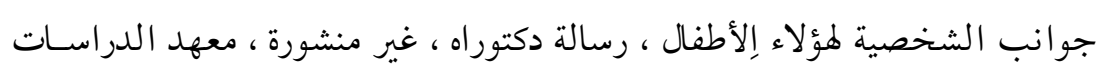

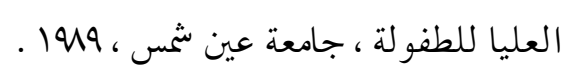

19-Palmarus,-Kerstin : the Impect of Ratio of children carr Giver on social Interaction and Activity pattern on a day care center Earlu-child Development and care, Vol , (61),1991

•r- هناء أبو شهبه : مدي الرضا لدي أبناء قرية الأطفال عن أسـاليب الرعايـة وعلاقتـه.

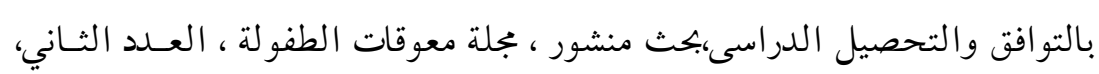

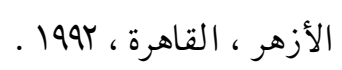

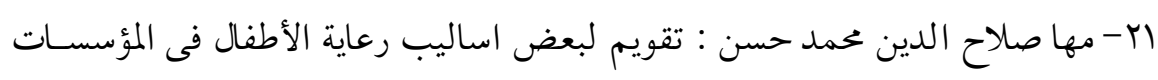

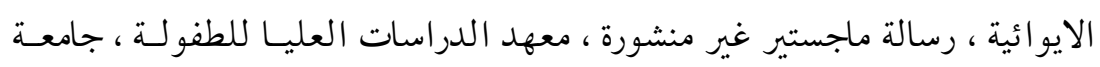

$$
\text { عين شمس الو } 1991 \text {. }
$$


22-Laufer Zmira : the Ni Man's and of Home meek ends for children in Resident care' Journal of child a buss Neglect , Russia, Vol 18,1994.

23-Edmiston, Baird : the followed Care in the accommodation institute on the lodger children, Alaska, university go Pennsylvania U.S.A,2004.

24-Presciutti,Dians Bullen: The visual culture of the founding hospital in congeal Italy, university of michgan,2008

$$
\text { Oب - }
$$

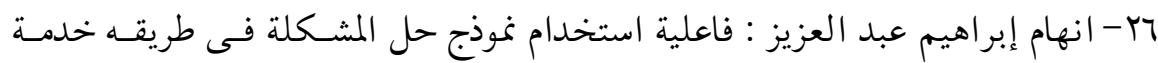

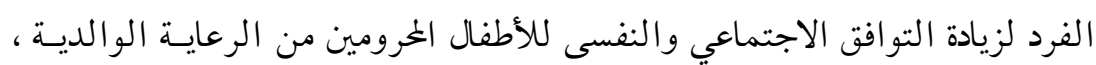

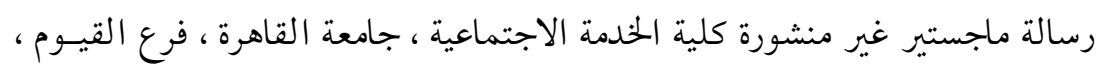

.199.

يوسف لطفى غبريال : مدي فاعلية التدخل المهني لخدمة الفرد فى تعـديل مفهـوم

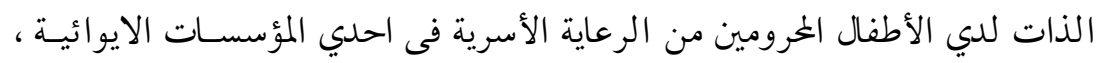

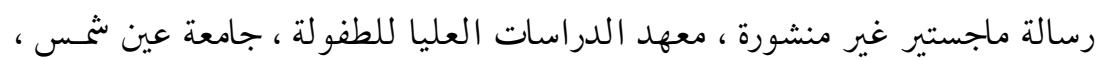

$.199 \mathrm{~V}$

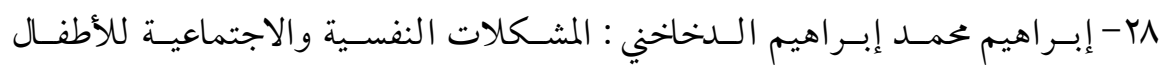

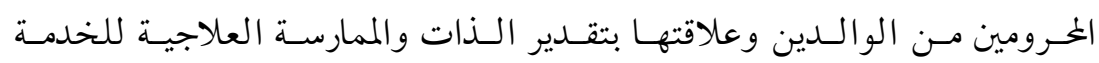

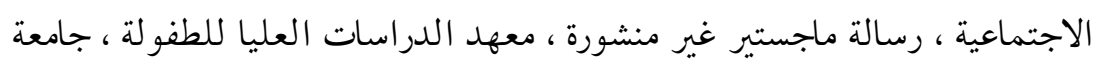

$$
\text { عين شنس ، } 1999 .
$$

هץ- هناء أحمد أمين : فعالية العلاج المتمركز حول العميل فى خدمــة الفـرد فـى تعـديل

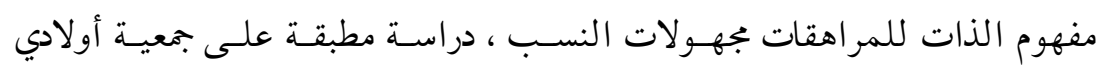

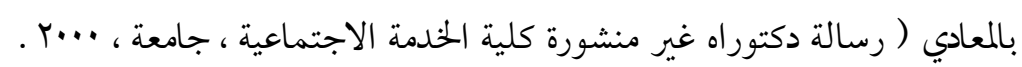

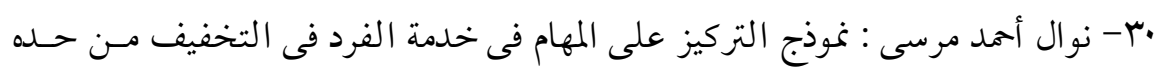

اضطرابات العلاقات الاجتماعية للأطفال الايتام ، رسالة دكتوراه غير منشورة ، كلية

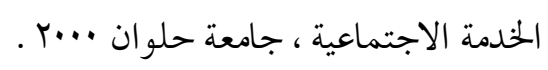


M- ناظك عيسى عفيفى : بر نامج مقترح للعمل مع جماعـات الأطفـال بجهـولى النسـب

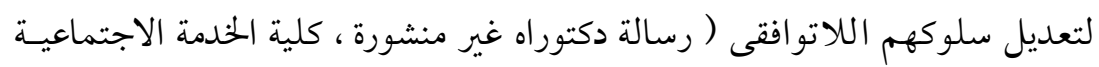

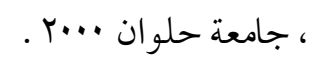

با - عاطف خليفة محمــ : التـدخل المهـني للخدمـة الاجتماعيـة والتخفيـف مـن حـــة المشكلات الاجتماعية والنفسية التى يعاني منها الأطفال بجهولى النسب بالمؤسسات

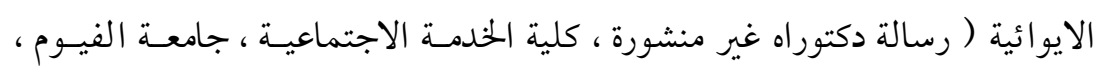
r..r

سٓ-صفاء عادل مدبولى راشد : فعالية العلاج الواقعي فـى تنميـة المسـئولية الاجتماعيـة

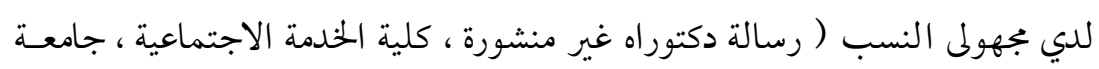

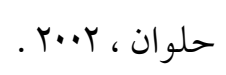

34-Clodder\&warth : Encognitive Gedragsinera pettish programmer onderdell overran (semi) Residential behandeling van Kinden matemotional sloornissen Ia cognitive Behavioral therapeutic program partout (somi) Residentail treatment for children with emotional disorder, child study ( Journal , vol.18 14 , 2004

0ب- محمد طه أحمد جاهين : العلاقة بين ممارسة نموذج التركيز على المهام فى خدمة الفـرد

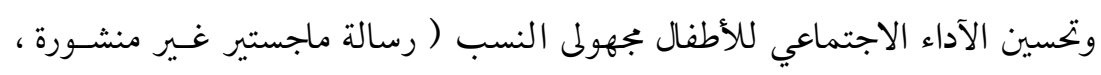

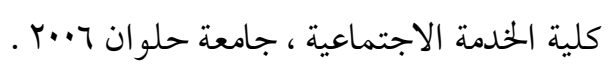

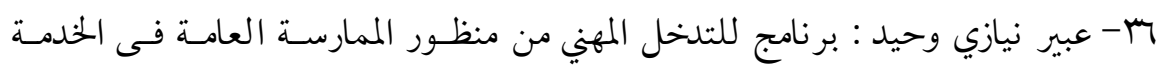
الاجتماعية لوقاية الاطفال بجهولى النسب من المخاطر الاجتماعية ، رسـالة دكتـوراه

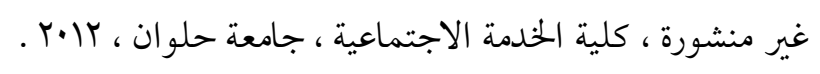

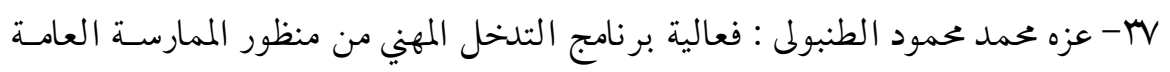

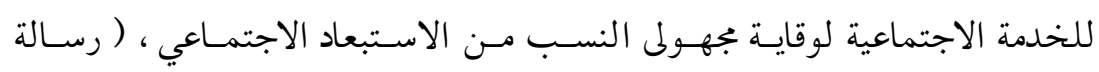

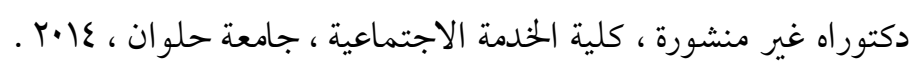

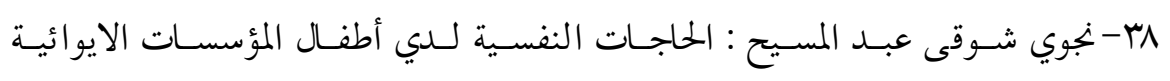

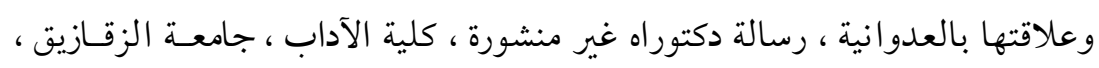


وب- فاتن السيد على أبو صباغ : دراسة مقارنة للمشكاتلات السلوكية التى يتعـرض هـا كل من أطفال المؤسسات ، وأطفال قرى الأطفال (S.O.S) ( رسالة ماجستير غـير منشورة معهد الدراسات العليا للطفولة ، جامعة عين شثس 1991. •ع- ساميه صابر الدندراوى : دراسة تحليلية لنتائج بعض عمليات النمـو المعرفى لـدي

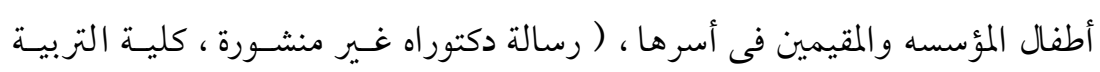
جامعة حلوان ، 1991 .

41-Cloudia fanseca: Orphanages, Foundlings , Faster Mother : The system of child circulation in brazilin spates Settlement anthropological Quarterly, vol . (59) : 2003. rأ- أمال عبد السميع المليجي : القلق والاكتئاب لدي أطفال دور الرعايـة الاجتماعيـة ،

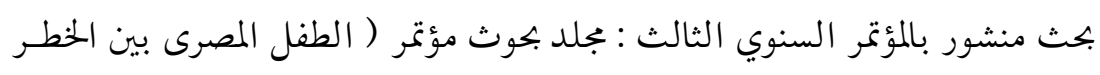
والأمان ) معهد الدراسات العليا للطفولة ) جامعة عين شمس ، 1990 .

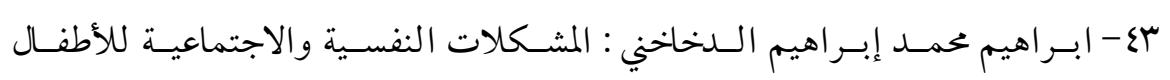
الخرومين من الوالدين وعلاقتها بتقدير الذات ، مرجع سبق ذكره . ع؟- محمد رشدي محمد : تقويم فعالية المؤسسات الايوائية فى مواجهة مشـكلات الايتـام

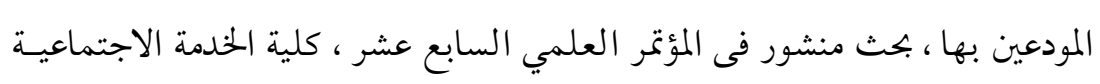

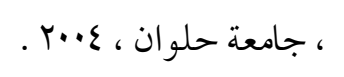

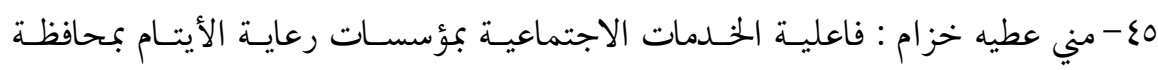

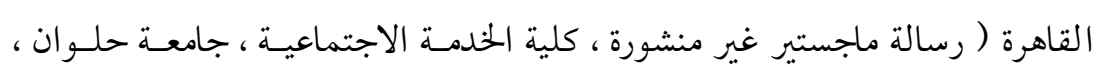
.199. 7צ- هناء أحمد أمين محمد : دراسة مقارنة فى نظــام الرعايـة بــين الأطفـال جمعيـة أولادي

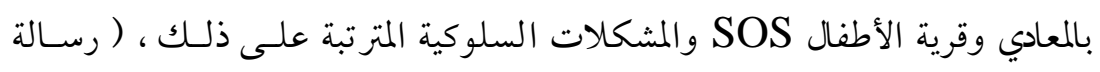
ماجستير غير منشورة، كلية الخدمة الاجتماعية ، جامعة حلوان ، 1990 . Vح - المتولى أبراهيم ابراهيم : دراسة لأساليب الرعاية المقدمة لأطفال المؤسسات الايوائية

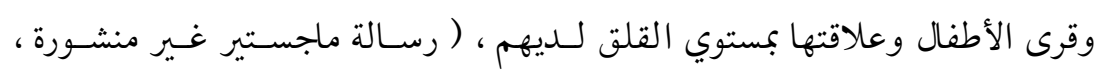




$$
\text { معهد الدراسات العليا للطفولة ، جامعة عين شمس ، } 1990 \text {. }
$$

48-Colen , Yacheskiet: Attachment as the basis of psychopathological development and residential treatment (Journal, Psychoanalytic study of eht child(52).1997.

49-Bynmen , and others :Social Exclusion and the case of young people rot in education, employment, or training, ( Journal of vocation Behavior, Vol 60(2),2002

•0- مني عبد اللطيف عبد الحميد جاد الحق : قصور برامج الرعاية الاجتماعية وعلاقتها

بالاضطرابات السيكوسوماتيه والانحرافات السلوكية لدي أبناء المؤسسات الايوائيـة

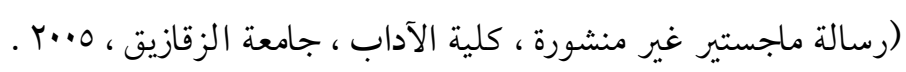

51-Nanarro-diaz, Criseyde : Economic advancement or Social Exclusion less- educated markers courts of living and migration in high - recursions ph.d.,(masaahudtts Instlute of technology,2005.

ror-حنان زكريا السيد الدسوقى : دراسة تقومية لبرامج الرعاية الاجتماعية للمؤسسات

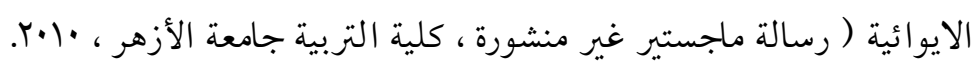

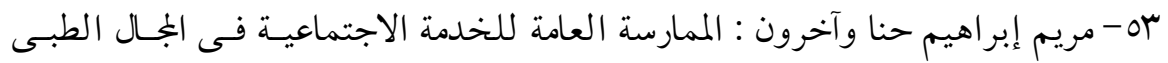

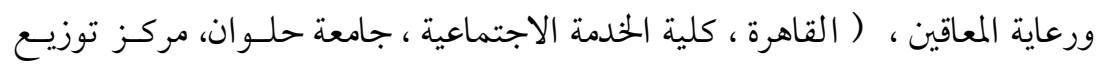

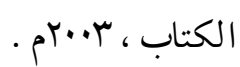

54-John.F.I.: social Work Practice, Generalist Approach Boston, Ally and Bosston,2000.

ه- هشام سيد عبد الجميد وآخرون : المدخل إلى الممارسة العامة فى الخدمــة الاجتماعيـة ،

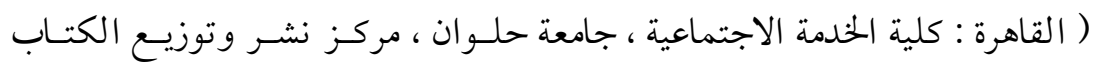

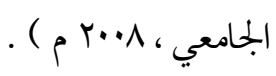

56-A shman, K.Hullg: Generalist Practice With Organization and Communities ,Chicago .Nelson Hall,1997.

57-Alissabeth March. E.T. al the General Method of social Work Practice, Boston, Ally Boston , 2002. 1ه - ماهر أبو المعاطي على : الاتجاهات الحديثة فى بجالات الخدمة الاجتماعية ، ( الرياض

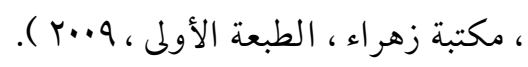


59-Sott W.Boyle et al.,: Direct Practice in Social work (Boston : Pearson Education,Inc.,2006.

•- الاتحاد الاقليمي للجمعيات الأهلية : بيان بالمؤسسات والجمعيات بمحافظة الدقهلية.

آT-وزارة التأمينــات والشـئون الاجتماعيـة ، الادارة العامـة للأســـة والطفولــة ، ادارة الرعايـة البديلـة : اللائحــة النموذجيــة لمؤسســات الرعايـة الاجتماعيـة للأطفــال

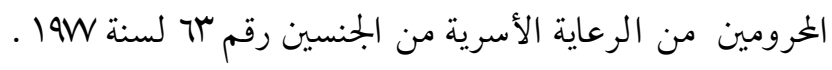
بآ- مها صلاح الدين : تقويم لبعض أسـاليب رعايـة الأطفـال بالمؤسسـات الايوائيـة ، مرجع سبق ذكره .

سآ- محمد طلعت عيسى وآخــرون : الرعايـة الاجتماعيـة للأحسـداث المنحــفين ، مكينـة القاهرة الحديثة ، القاهرة 1917 . 197

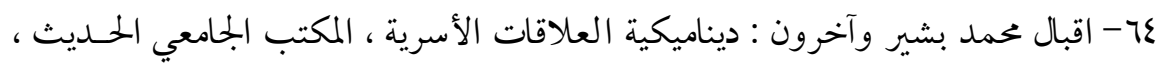
الاسكندرية ، 1999.

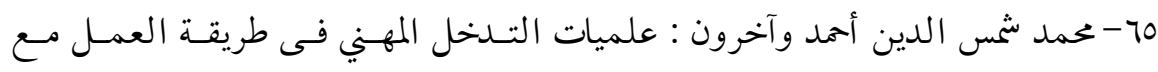
الجماعات ، القاهرة ، 1997 . 199

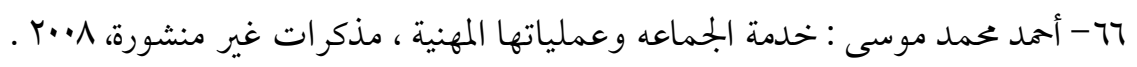

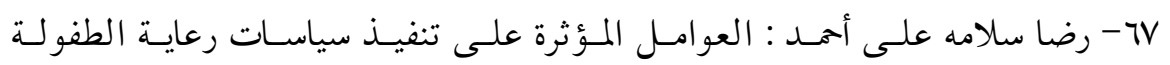
بالجمعيات الأهلية ، مجلة دراسات الخدمـة الاجتماعيـة والعلـوم الانسـانية ، العـدد

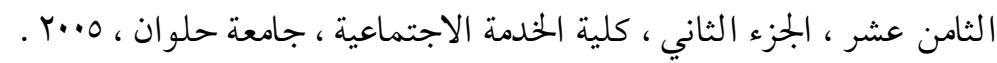
لح- عادل رضوان عبد الرازق الهواري : التدخل المهـني بطريقـه تنظيم الجتمـع لتطـوير

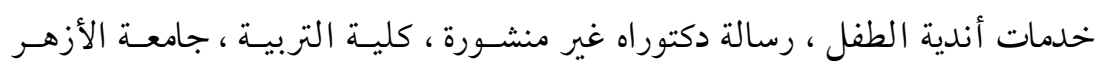
.$r \cdot V$ 79- هالة خورشيد ، دراسة تقويمية لبرامج أنشطة أندية الأطفال بححافظة الفيوم ، رسـالة

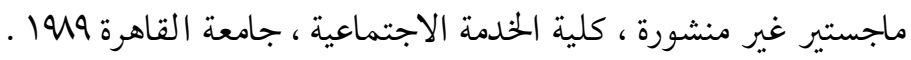

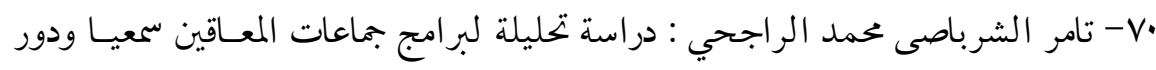


خدمة الجماعة فى تطويرها ، رسالة ماجستير غير منشورة كلية الخدمــة الاجتماعيـة ،

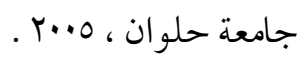

1 - Vممد صالح بهجت : خدمة الجماعة ، المكتب الجامعي الحديث ، الاسكندريه ، 1910.

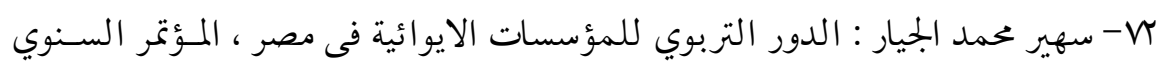

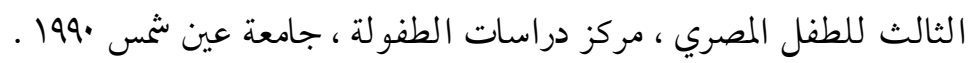

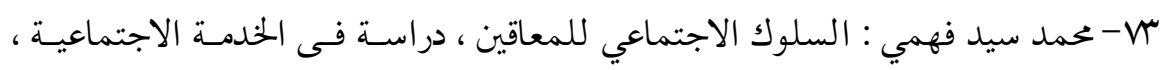

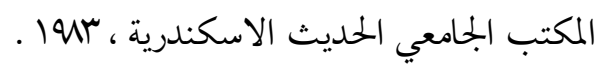

